\title{
Hizbullah's Changing Identity
}

\author{
By Glenn Davy
}

A Thesis Submitted to the Victoria University of Wellington in Partial Fulfilment of the Requirements for the Degree of Master of International Relations (MIR)

School of History, Philosophy, Political Science and International Relations

Victoria University of Wellington 2013 


\begin{abstract}
Hizbullah's initial entry into Lebanon's confessional political system seems contradictory considering the organisation's perpetual view that this electoral system is corrupt and the very cause of Lebanon's problems. Hizbullah views this system to have disenfranchised the Shi'a of Lebanon.

Since its emergence in the 1980s Hizbullah has shifted from the religiously motivated goal of an Islamic revolution in Lebanon to the more nationalistic and secular project of providing ongoing resistance to Israel. This movement can be explained if we consider two separate facets of Hizbullah's identity: It's primordial Shi'a identity, and its identity as a resistance movement. A movement from the former to the latter has taken place.

This work argues that Hizbullah has moved away from placing importance on that which defined it primarily as an organisation seeking the advancement of Shi'a to an identity that places more emphasise on its resistance activities against Israel. This latter identity is more instrumentalist in nature. While placing importance on its Shi'a identity was not counter-productive to participating within politics, it did oblige Hizbullah to adopt more idealistic political projects. Therefore, this shift initially allowed Hizbullah to deal more effectively with the pragmatic realities of political life in Lebanon, for which it requires more broad-based cross-communal support. However, recent events in the Middle East have indicated that Hizbullah's resistance identity may not necessarily guarantee it political success.
\end{abstract}




\section{Contents}

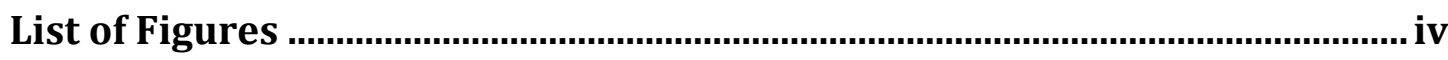

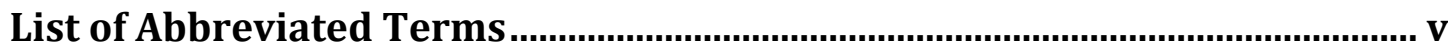

Note on Transliteration....................................................................................... vi

Introduction ........................................................................................................ vii

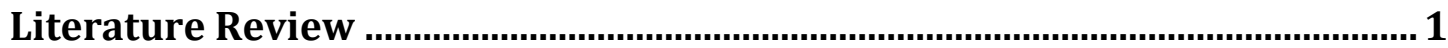

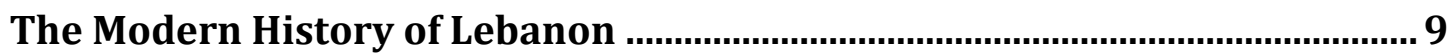

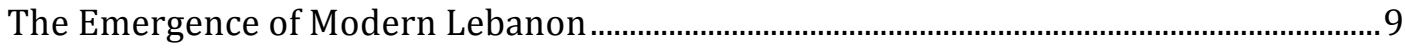

The National Pact and the Formation of a Confessional Government ............................... 17

The Lebanese Civil War ............................................................................................................... 22

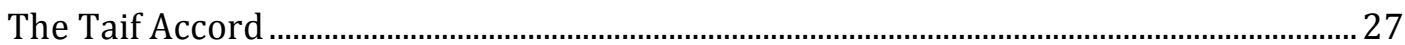

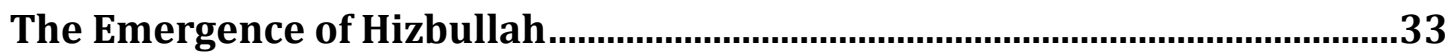

The Shi'a of Lebanon and the Emergence of Shi'a Politics ............................................... 34

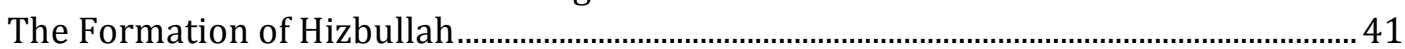

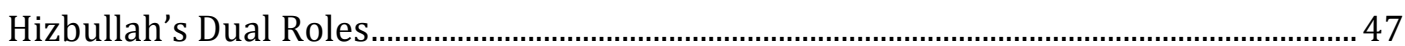

Hizbullah's Wavering Public Support............................................................................... 51

Hizbullah's Identity Transformation ..............................................................62

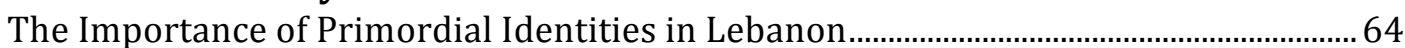

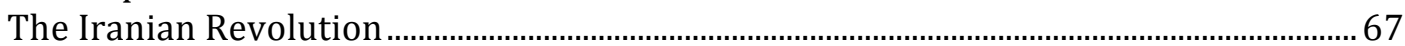

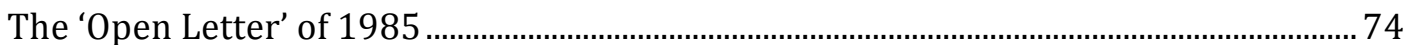

The Instrumentalist Turn in Hizbullah's Identity ................................................................. 77

The 'New Manifesto' of 2009...................................................................................................... 79

Conclusion

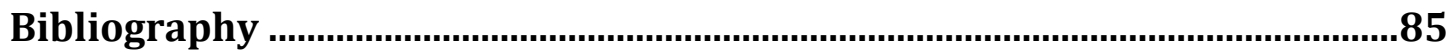




\section{List of Figures}

Figure 1: The major cities, towns, villages and administrative regions of Lebanon

Figure 2: Demographic distribution of the major confessional groups within Lebanon.

Figure 3: Census results as presented to the French authorities by the Lebanese Government.....................................................................15

Figure 4: Hizbullah's social services.................................................58

Figure 5: The location of Hizbullah's welfare agencies and the demographic distribution of Shi'a Muslim communities. .59 


\section{List of Abbreviated Terms}

$\begin{array}{ll}\text { ADF } & \text { Arab Deterrent Force } \\ \text { IDF } & \text { Israel Defence Forces } \\ \text { LAF } & \text { Lebanese Armed Forces } \\ \text { LCP } & \text { Lebanese Communist Party } \\ \text { PLO } & \text { Palestine Liberation Organisation } \\ \text { PNC } & \text { Palestinian National Council } \\ \text { SLA } & \text { South Lebanese Army } \\ \text { UAR } & \text { United Arab Republic } \\ \text { UN } & \text { United Nations } \\ \text { UNIFIL } & \text { United Nations Interim Force in Lebanon }\end{array}$




\section{Note on Transliteration}

There is no one universal system for the transliteration of Modern Standard Arabic into English. Hence, there are often numerous variant spellings for even relatively common Arabic proper names and terms found in English works, for example, 'Hizbullah', 'Hezbullah', 'Hezbollah', 'Hizballah', etc. For the sake of consistency the simplified method of transliteration used by alJazeera, as it relates to their publishing, has been followed. 


\section{Introduction}

In 1966, just as Lebanon was entering, what was to prove, a short-lived 'golden period' of apparent civility and prosperity, Edward Still wrote that there was "... no public in Lebanon... only constituencies defined by primordial attachments and beliefs... "1. Still then went on to explain that these attachments, and their mutual interests, were immune to parliamentary intervention. These words essentially capture the fundamental problem that has beset Lebanon since its inception; that the various ethnic groups have not adhered to any overarching national identity, they have largely continued to represent their own interests at all levels of government. Yet Lebanon is arguably the most democratic Arab state in the Middle East. Debate is lively among its numerous political parties, and these are reported in a relatively free media ${ }^{2}$. Yet, ethnic loyalties had hindered any real sense of nationhood, or full democracy, since the modern state's inception in 1920. Indeed, any idea of a Lebanese identity had failed to arise in that time. And this aforementioned period of seeming affluence was in fact masking Lebanese society's worsening fragmentation. Any cohesion was being stymied by the various ethnic groups' deep-seated adherence to their own primordial ethnic identities. Within Lebanon, such divisions were to soon be completely unveiled; within nine years the country was to enter fifteen years of darkness, as its society disintegrated and its various factions embarked on a particularly bloody civil war.

This war ended in 1990 with nothing having significantly changed. Society was now more heterogeneous that ever, and the same confessional political system still preserved the power imbalances between the country's different ethnic groups. However, the particularly disenfranchised Shi'a

\footnotetext{
${ }^{1}$ Shils, E. (1966). Introduction. In L. Binder (Ed.), Politics in Lebanon (p. 345). New York: John Wiley and Sons, p. 3; cited in Cobban, H. (1985). The Making of Modern Lebanon. London: Hutchinson Publishing, p. 79.

${ }^{2}$ Choucair, J. (2006). Lebanon: Finding a Path from Deadlock to Democracy. Carnegie Endowment for International Peace. Washington DC: Carnegie Endowment for International Peace Publications Department, p. 3.
} 
Muslims now found themselves with a new advocate in Hizbullah, and the already crowded political space of post-war Lebanon now had an additional player that was to greatly complicate the political space. This militia emerged in 1982 as a result of Israel's invasion of Lebanon, for which the Shi'a community in Southern Lebanon had suffered the most under their aggression $^{3}$.

The Shi'a Muslim population of Lebanon has traditionally been located in southern Lebanon and the north eastern region of the Bekaa Valley, Lebanon's two main agricultural regions ${ }^{4}$. As such, the vast majority of the Shi'a population has historically been comprised of a rural underclass. Due largely to this, the Shi'a community has traditionally been marginalized from Lebanese politics and, until recently, has been the least politically represented community within Lebanon ${ }^{5}$. Due to its ascendancy Hizbullah has supplanted other, more secular Shi'a political parties such as the Amal Movement ${ }^{6}$. As a result it has now emerged as a major political force within Lebanon, transforming the regional dynamics of the Middle East.

Originally, Hizbullah's leaders had rejected any participation in national politics, arguing that any participation in the 'corrupt' confessional system would only serve to legitimize it ${ }^{7}$. It therefore came as a surprise to a large part of the Lebanese population when Hizbullah decided to participate in the Lebanese elections of 1992. This decision by the group was made after overcoming internal divisions ${ }^{8}$ and then not until they received the 'blessing' of Iran's Ayatollah Khamenei ${ }^{9}$. Hizbullah stated at the time that its

\footnotetext{
${ }^{3}$ Norton, A. R. (2007). Hezbollah: A Short History. Princeton: Princeton University Press, p. 34.

${ }^{4}$ Kliot, N. (1986). Lebanon - A Geography of Hostages. Political Geography Quarterly , 5 (3), p. 208.

${ }^{5}$ Shanahan, R. (2011). The Shi'a of Lebanon (2nd Edition ed.). London: I. B. Tauris \& Co Ltd, p. 3.

6 'Amal' is a Shi'a political group established by Musa al-Sadr in 1974. It will be examined more thoroughly within the body of this work.

7 Noe, N. (Ed.). (2007). Voice Of Hezbollah: The Statements of Sayyed Hassan Nasrallah. (E. Khouri, Trans.) London: Verso, p. 99.

${ }^{8}$ Harb, M., \& Leenders, R. (2005). Know Thy Enemy: Hizbullah, 'Terrorism' and the Politics of Perception. Third World Quarterly, 26 (1), p. 185.

${ }^{9}$ Noe, op. cit., p. 74.
} 
entry into politics was to represent the Shi'a community, which it argued had been consistently neglected by the state.

From the time since its emergence, and particularly after it decided to enter politics in 1990, Hizbullah has expressed continual dissatisfaction with the confessional constitution as initially set out in the National Pact of 1943. This was in part because the pact assigned executive political positions to the numerous confessions based upon Lebanon's 1932 census, a poll that now no longer reflected Lebanon's demographics. Maronite Christian's, the largest ethnic group in 1932, were at that time given the position of the state's presidency. By the 1980's the Shi'a community had grown to comprise at least $30 \%$ of the population, making them now the largest ethnic group in Lebanon, and yet they still only retained the Speaker of the House position under the pact ${ }^{10}$. In addition to this, Hizbullah had been dissatisfied with the Taif Accord of 1989 which bought about the end of the civil war, and which did in fact make concessions partly in its favour. This is because the Taif Accord effectively "enshrined sectarianism", which Hizbullah considers to be a retrograde step ${ }^{11}$. Contrary to this confessional approach, Hizbullah favoured a consensual electoral system, if not a majoritarian one ${ }^{12}$. That is, a decision-making approach based on the participation of all parties, if not one based on the rule of a majority block, of which they were obviously to be a part.

Hizbullah's entry into politics eventually meant that the organisation found itself requiring broad-based and cross-communal support for its political projects. This has necessitated the organisation needing to identify with something other than that defining it principally as an advocate for the Shi'a community. This paper argues that Hizbullah has moved away from is primordial definition of being Shi'a, to the more instrumentalist mode of presenting itself as a resistance movement. As it has not dispensed

\footnotetext{
${ }^{10}$ Hamzeh, A. N. (2004). in The Path Of Hizbullah. Syracuse, New York: Syracuse University Press, p. 12.

11 Noe, op. cit., p. 74.

12 Hamzeh, op. cit., p. 144.
} 
completely with its Shi'a identity, Hizbullah now essentially bears two dichotomous identities that at dichotomy in fact belies many binary oppositions within the organisation; a Shi'a identity verses a Resistance identity, idealism verses realism, religious concerns verses earthly matters, and revolution verses resistance. Two particular documents; the 'Open Letter' of 1985 and the 'New Manifesto' of 2009, have exemplified this evolution in Hizbullah's identity.

The question that this thesis examines is how can we explain Hizbullah's entry into a political system that it has variously described as 'corrupt' and counter-productive to national interest, and how does the fostering of these two identities further this? It will be found that the answers to these questions are found not only in local, national exigencies, but also within the influence of regional powers such as Syria and Iran.

This thesis is divided into five main chapters. The first chapter will review the extensive literature pertaining to both Hizbullah and the political situation in Lebanon in general. There has been a marked increase in both academic and general literature regarding Hizbullah, but much of it does not look at the organisation fairly; often the organisation has been essentially dismissed as a terrorist group and nothing more. This obviously limits any appreciation of its current status in Lebanon, and its effective social service activity. This section will therefore also argue for a more holistic view of Hizbullah, rather than the usual polarised view of the organisation as either a terrorist group or as a purely political party. Chapter 2 will examine the modern history of Lebanon from its formation as a modern state in 1920 until the present day. Lebanon has experienced an inordinately complex history since its formation, and an exhaustive history is beyond the scope of this thesis. However, as the section seeks to provide a context from which Hizbullah emerged, only the salient points as regards to the organisation's formation will be covered. To this end this section will examine the National Pact of 1943, the civil war from 1975 until 1989, and the Taif Accord of 1990. Chapter 3 examines the emergence of Hizbullah, and its movement 
from being an ideologically driven militia to a participant in the political arena. Despite the apparent reason for Hizbullah's emergence appearing to be because of wartime exigencies, this section will demonstrate that it was, in fact significantly driven by the slow process of politicisation Shi'a Muslims undertook since the state's inception. Chapter 4 will consider the fundamental change in Hizbullah's identity as it has adapted to the practical realities of both Lebanon and the region. Hizbullah's initial primary identification was with Shi'a Muslim was particularly evidenced by the 'Open Letter' of 1985 . This section will argue that this identity, which is primordial in nature, is primarily the result of Iranian patronage, and was essentially the exportation of the Iranian Revolution into Lebanon. A brief overview of that revolution therefore will demonstrate how primacy was placed on the religious edicts of the Ayatollah, that is, the wilayat al-faqih, and that these, initially at least, applied to Hizbullah as well. This adherence to the revolution in Iran marked Hizbullah primarily as a Shi'a organisation. This chapter will then move away from this primordial Shi'a identity and examine Hizbullah's resistance identity, which is more instrumentalist in nature. This section argues that Hizbullah now places more importance on this identity, and that this was necessitated by its entry into national politics. It will be demonstrated by particularly appealing to the 'New Manifesto' released by the organisation in 2009, which, while still averse to Lebanon's confessional system, outlines a policy that is more conducive to acquiring popular support for the organisation's projects. The final chapter will conclude the thesis by looking at what this means for the future of the organisation in Lebanon in light of the events of the so-called 'Arab Spring'. Since its formation, Iranian patronage has declined; Hizbullah may now also loose the same from Syria. Therefore, this thesis will also examine what the current strife in Syria means for the organisation as well. 


\section{Literature Review}

That much of the literature on modern Lebanese history examines sectarian strife is not surprising considering the relatively recent civil war, the subsequent breakdown of Lebanese civil society, and Lebanon's ensuing faltering steps to reestablish itself. However, this focus has resulted in a dearth of serious academic literature examining the particular various ethnic communities within Lebanon. This is especially the case with the Shi'a of Lebanon. That this is so can partly be accorded to the fact that the Shi'a community has historically been relatively politically quiescent in, and therefore absent from, Lebanese affairs ${ }^{13}$. But this omission is also surprising considering the rapid politicisation of the Shi'a community in not just Lebanon, but throughout all of the Middle East, in the last thirty years. Both Augustus Richard Norton's Amal and the Shi' ${ }^{14}$ and Rodger Shanahan's The Shi'a of Lebanon: Clans, Parties and Clerics ${ }^{15}$ attempt to redress this. Norton's book, first published in 1987 and before the implications of Hizbullah's emergence become known, examines the politicisation of Shi'a, and sees the Amal movement as the inevitable manifestation of this. In his book published in 2011 Shanahan has the privilege of hindsight and recognises the importance of both Hizbullah and Amal in galvanising Shi'a within Lebanon, but views these two organisations rather as manifestations of the gradual movement away from the traditional $z u^{\prime} a m a^{16}$ system of patronage that began in the 1960's. For Shanahan, Hizbullah's recent movement into politics can only be fully explained within this context, and as dominant as this organisation has become it is still not the full story of Lebanese Shi'a in general. Roschanack Shaery-Eisenlohr similarly views Hizbullah as only being a part of a greater Shi'a movement in her book

\footnotetext{
${ }^{13}$ Shanahan, op. cit., p. 2.

${ }^{14}$ Norton, A. R. (1987). Amal and the Shi'a. Austin, Texas: University of Texas Press.

${ }^{15}$ Shanahan, op. cit.

16 The zu'ama system is a clan-based arrangement of social ordering centered around family allegiances that favours a preference for client-based patronage. It will be more fully explained within the body of this work. See Shanahan, R. (2011). The Shi'a of Lebanon: Clans, Parties and Clerics. New York: I. B. Tauris \& Co Ltd, pp. 39-44.
} 
Shi'ite Lebanon: Transnational Religion and the Making of National Identities $^{17}$. However, Shaery-Eisenlohr views the galvanisation of Shi'a since the 1960's not purely as a process of politicisation but as the nationalisation of Shi'a identity primarily to counter the hegemonic primordial Christian national identity principally perpetuated by Maronites $^{18}$. For Shaery-Eisenlohr Hizbullah is just one of many ethnic Shi'a entrepreneurs operating within Lebanon, and as such is in competition with the likes of Amal and others in forging a national Shi'a identity. Hizbullah's politicisation is then just one aspect of this larger project.

Hizbullah's eventual entry into politics and its explicit favouring of a majoritarian electoral system ${ }^{19}$ challenges Lebanon's political future. The irony here, considering the copious amounts of literature about Hizbullah, is that the organisation is very rarely examined purely as a political entity or a purveyor of social services, but rather as an insurgent militia with political intent at best, or as a terrorist organisation at worst. Such a dichotomous view of Hizbullah does not always serve to capture its complexity ${ }^{20}$. Mona Herb and Reinoud Leenders note that whilst many, invariably western, countries denote Hizbullah as a terrorist organisation to one degree or another, it in fact has not committed any explicit terrorist acts since the chaotic latter years of the Lebanese civil war ${ }^{21}$. Judith Palmer Harik's book Hezbollah: The Changing Face of Terrorism ${ }^{22}$ typically exemplifies this, effectively revealing its position on the matter in its title. In it Harik seeks to answer the question of whether Hizbullah is a legitimate resistance movement and political actor within Lebanon or simply a terrorist group. Yet published as it was in 2005, one could argue that the organisations successful entry into politics, as well as the events of 2000 (when the group

\footnotetext{
17 Shaery-Eisenlohr, R. (2008). Shi'ite Lebanon: Transnational Religion and the Making of National Identities. New York: Columbia University Press.

18 Ibid, p. 2.

19 Hamzeh, op. cit., p. 144.

${ }^{20}$ Harb, M., \& Leenders, R., op. cit., p. 173.

21 Ibid, p. 178.

${ }^{22}$ Harik, J. P. (2004). Hezbollah: The Changing Face of Terrorism. London: I. B. Tauris \& Co Ltd.
} 
in part brought about the withdrawal of Israel from Lebanon) had already answered that belated question. Moreover, labelling the organisation as a terrorist group allows unfounded accusations and claims to be made about the organisation beyond the usual acceptable bounds of reputable academic discourse. Erroneous claims such as an unfounded connection with al Qaeda, overstating Iranian and Syrian influence, and understating its social services to Shi'a has therefore often resulted ${ }^{23}$. Furthermore, seeing the organisation as purely political or purely military also fails to examine the relationship between these two facets ${ }^{24}$, and Harb and Leenders consequently argue for a more holistic view of Hizbullah that acknowledges its hegemonic representation of Lebanese Shi'a ${ }^{25}$. This approach allows for a more 'grass roots' examination of the social service aspects of the organisation that have come to define it in the new millennia ${ }^{26}$. Nevertheless, much of the literature continues to simplistically place Hizbullah somewhere on a continuum between politics and insurgency. The exception is perhaps Dominique Avon and Anaïs-Trissa Khatchadourian's book Hezbollah: A History of the "Party of God"27. Published in 2012 it has the benefit of examining the organisation in light of the so-called 'Arab Spring'. Hizbullah has generally supported these revolutionary struggles in neighbouring countries, and has posited itself as a liberation movement in solidarity with these struggles. Unfortunately the book was published before the Syrian manifestation of the 'Arab Spring' transformed into a civil war. In this instance Hizbullah has actually sided with the regime. Nevertheless, the book provides a balanced view of all facets of the organisation, including these apparent hypocrisies.

\footnotetext{
${ }^{23}$ Harb, M., \& Leenders, R., op. cit., p. 179

24 Ibid, p. 185

25 Ibid, p. 175

26 Ibid, p. 183

${ }^{27}$ Avon, D., \& Khatchadourian, A.-T. (2012). Hezbollah: A History of the "Party of God". (J. M.

Todd, Trans.) Cambridge, Massachusetts: Harvard University Press.
} 
In Hizbullah: A Short History, another book by Augustus Richard Norton, a balanced, if simplistic, historical analysis is provided that encompasses all facets of the organisation and examines the party's movement from simply an armed militia into a political party ${ }^{28}$. Norton views this development from 'extremist ideals' to 'mundane politics' primarily as a turn to the practical reality of political expediency ${ }^{29}$. In The Shifts in Hizbullah's Ideology: Religious Ideology, Political Ideology and Political Program ${ }^{30}$ Joseph Alagha correspondingly argues that Hizbullah's shift from a predominantly military or insurgent organisation to a political presence within Lebanon is the result of the realisation that it needs to adapt to the pragmatic realities of the Lebanese political system. Alagha notes that this does not necessarily denote a shift in ideology, as Hizbullah's political platform is one that still retains a central jihadist/resistance doctrine based on Islamic principles ${ }^{31}$, something my work argues is not necessarily the case. In his book In the Path of Hizbullah ${ }^{32}$ Ahmad Nizar Hamzeh similarly views Hizbullah's practical entry into politics as the result of 'crisis conditions' within the Lebanese Shi'a community. However, Hamzeh goes further in stating that, despite Hizbullah's realisation of the practical realities of Lebanese politics, it still retains the ultimate goal of establishing an Islamic order therein, something that Norton no longer considers dominant within Hizbullah ideology 33 . Hamzeh, while acknowledging Hizbullah's military aspects, sees it primarily as a vertical political party providing a myriad of social services to its patrons, the disenfranchised Shi'a of Lebanon ${ }^{34}$. These obligations stem largely from Hizbullah's religious ideology, in that social service is a central tenet of the Islamic faith, but that this has in turn significantly bolstered Hizbullah's place within Lebanese society in general, and the Shi'a

\footnotetext{
${ }^{28}$ Norton, A. R. (2007). Hezbollah: A Short History (1st ed.). Princeton: Princeton University Press.

${ }^{29}$ Norton, A. R. (1999). Hizballah of Lebanon: Extremist Ideals vs. Mundane Politics. Council on Foreign Relations. New York: Council on Foreign Relations; Norton, A. R. (1998).

Hizballah: From Radicalism to Pragmatism? Middle East Policy , 5 (4), pp. 147-158.

30 Alagha, J. E. (2006). The Shifts in Hizbullah's Ideology: Religious Ideology, Political Ideology and Political Program. Amsterdam: Amsterdam University Press.

31 Ibid, p. 199.

32 Hamzeh, A. N. (2004). in The Path Of Hizbullah. Syracuse, New York: Syracuse University

Press.

33 Norton, op. cit., p. 158.

${ }^{34}$ Hamzeh, op. cit., p. 49.
} 
community in particular ${ }^{35}$.

Finally, less objective, but no less valuable information is to be gained through examining the documents, literature and transcripts of speeches from the organisation proper, as well as its representatives. Despite being relatively guarded in detailing its organisational structure and operations, Hizbullah has incongruously become one of the most media savvy political organisations within Lebanon and the greater Middle East. With Al-Manar, its television network, four radio stations and five newspapers, Hizbullah's reach is not just regional but international ${ }^{36}$. These mediums, not surprisingly, further Hizbullah's ideological cause, but in recent years have also advocated for other causes where they perceive their Muslim brethren to be oppressed ${ }^{37}$. In addition to this, beginning with its 'Open Letter' of 1985, Hizbullah has continually published various manifestos, programs, pacts, agreements and policy statements. Joseph Alagha has compiled these various documents into a single volume in Hizbullah's Documents: From the 1985 Open Letter to the 2009 Manifesto $^{38}$. This compendium affords a chronological mapping of the dynamic changes that Hizbullah has undergone since its inception. This is complemented by Voice of Hezbollah: The Statements of Sayyed Hassan Nasrallah, in which Nicholas Noe has compiled a comprehensive collection of the significant statements, speeches and interviews given by Sayyed Hassan Nasrallah, the secretary general of Hizbullah $^{39}$. Traversing Nasrallah's fourteen years of leadership from when the organisation was a relatively zealous militia to its more recent invocation as an incisive player on the political scene, Noe's collection reveals an astute statesman able to navigate the intricacies of Lebanese politics. Nasrallah's cohort, Naim Qassem, the deputy secretary general of

\footnotetext{
35 Ibid, p. 53.

36 Ibid, p. 58.

37 Ibid, p. 60.

38 Alagha, J. (2011). Hizbullah's Documents: From the 1985 Open Letter to the 2009 Manifesto. Amsterdam, 2011: Pallas Publications. ${ }^{39}$ Noe, N. (Ed.). (2007). Voice of Hezbollah: The Statements of Sayyed Hassan Nasrallah. (E. Khouri, Trans.) New York: Verso.
} 
Hizbullah, has also provided an inside account of the machinations of Hizbullah. Unsurprisingly biased in its perspective, Qassem's Hizbullah: The Story from Within nevertheless provides a valuable inside account of Hizbullah, particularly its views on the many external and internal forces it must deal with, namely Israel, America, the Lebanese government, and other Lebanese militias ${ }^{40}$.

Significant scholarly work regarding Lebanon in toto appears to have significantly declined after the end of the civil war in $1990^{41}$. Prior to this, academic interest in Lebanon's curious multi-ethnic society, and its divisions, was due to the general vogue in the 1970s of studying ethnic conflict, and the civil wars that often resulted. Here, Lebanon was often examined through the lens of consociationalism. Conscientious attempts to overcome ethnic divisions within societies usually results in various forms of power sharing. In order to overcome the simple tyranny of the majority ethnic or religious group, it was considered that majoritarian democracy needed to be constrained in some way by some form of power sharing, such as consociationalism. Consociational forms of power sharing have become associated with the work of Arend Lijphart in the 1960's, although such arrangements can be found much earlier such as the case of the Netherlands ${ }^{42}$. Consociational theory attempts to explain stability in ethnically pluralistic states and also attempts to establish a normative model for those states that are less democratic or have not been successful in ameliorating ethnic conflict ${ }^{43}$. The consociationalism model, as formulated by Lijphart, can be found in one form or another with the power sharing apparatus in Lebanon, and its electoral process is therefore usually

\footnotetext{
40 Qassem, N. (2005). Hizbullah: The Story From Within. (D. Khalil, Trans.) London: Saqi. 41 Schwerna, T. (2010). Lebanon: A Model of Consociational Conflict. Frankfurt am Main: Peter Lang, p. 23.

42 Lijphart, A. (1968). Typologies of Democratic Systems. Comparative Political Studies , 1 (3), pp. 3-44; McGarry, J., \& O'Leary, B. (2004). The Northern Ireland Conflict: Consociational Engagements. Oxford: Oxford University Press.

43 Yiftachel, O. (1992). The State, Ethnic Relations and democratic Stability: Lebanon, Cyprus and Israel. GeoJournal , 28 (3), p. 321.
} 
associated with this this political system ${ }^{44}$. Lijphart examined why ethnically diverse societies (usually) manage to sustain their political processes, and up until 1975 Lijphart generally considered Lebanon to present a successful model of how this could be done. However, in the case of Lebanon consociationalism promised much but in fact delivered very little; consociational forms of governance had only slightly mitigated ethnic tensions from the states inception. In 1975 consociational democracy completely failed and led to fifteen years of civil war in the form of intersectarian fighting ${ }^{45}$. With the outbreak of the war Lijphart felt that this did not necessarily represent a failure of Lebanon's consociational practices and electoral processes, but rather was the result of insurmountable external influences ${ }^{46}$. That is, the regional influences of Iran, Syria, Israel, the United States of America and France, as well as the Palestinian community. While some contemporary work now still refers to Lebanon's political system as consociational, the tendency now is to simply delineate it as sectarian or confessional.

Any examination of the modern political history of Lebanon invariably needs to examine the sectarian divisions that run through Lebanese society. These divisions are marked in various ways but are largely categorised along ethnic and religious lines. Undeniably, the modern history of Lebanon is now invariably seen as a history of failed sectarianism, and most literature dealing with contemporary Lebanon views it through this lens, often placing the blame squarely at the feet of the country's confessional political system in general, or consociationalism in particular. Both Helena Cobban's The

\footnotetext{
44 See Dekmejian, R. H. (1978). Consociational Democracy in Crisis: The Case of Lebanon . Comparative Politics , 10 (2), pp. 251-265; Majed, Z. (2011, September 8). On Consociationalism and Confessionalism in Lebanon. Near East Quarterly, pp. 1-8; Salamey, I., \& Payne, R. (2008). Parliamentary Consociationalism in Lebanon: Equal Citizenry vs. Quotated Confessionalism. The Journal of Legislative Studies, 14 (4), pp. 451-473.

45 Yiftachel, op. cit., p. 324.

${ }^{46}$ Lijphart, A. (1984). Democracies: Patterns of Majoritarian and Consensus Government in Twenty-One Countries. New Haven: Yale University Press, p. 40; cited in Schwerna, T. (2010). Lebanon: A Model of Consociational Conflict. Frankfurt am Main: Peter Lang, p. 20.
} 
Making of Modern Lebanon ${ }^{47}$ and Leonard Binder's Politics in Lebanon ${ }^{48}$ takes this view. Binder, in particular, argues that deep sectarianism continually fostered by consociationalism has resulted in a lack of national identity, and that the resultant sectarian conflicts have more often than not been attempts at winning the right to define a national identity. This is similar to A. J. Abraham's argument in Lebanon in Modern Times ${ }^{49}$, but where Abraham also argues that Lebanon lacks a cohesive national identity, it is as much because of foreign influences as it is about internal divisions. Finally, Kamal Salibi, in his book A House of Many Mansions: A History of Lebanon Reconsidered $^{50}$, published in 1988 just prior to the end of the civil war, similarly argued that sectarianism had reinforced communal divisions. Because of this, Salibi viewed the nation as a collective of differing perceived historical narratives with concomitant differing futures. Salibi accurately predicted a dire future for Lebanon, believing that its (then) present predicament could only be overcome by an agreement on a common vision of the past. Thus, sectarianism was at the heart of Lebanon's past difficulties and is integral to its future prospects. The well-known journalist Robert Fisk, who has specialised in Lebanese affairs, succinctly outlined this dilemma when he stated, "[as] long as it is sectarian, Lebanon cannot become a modern state. The problem is that without being sectarian, Lebanon will no longer exist"51.

\footnotetext{
47 Cobban, H. (1985). The Making of Modern Lebanon. London: Hutchinson Publishing Group.

48 Binder, L. (1966). Politics in Lebanon. New York: Wiley.

${ }^{49}$ Abraham, A. J. (2008). Lebanon in Modern Times. Lanham, Maryland: University Press of America.

50 Salibi, K. (1988). A House of Many Mansions: The History of Lebanon Reconsidered. 1988: Univesity of California Press.

51 Fisk, R. (2006, December 15). Who's Running Lebanon? Retrieved December 13, 2012, from The Independent: http://www.independent.co.uk/voices/commentators/fisk/robertfisk-whos-running-lebanon-428530.html
} 


\section{The Modern History of Lebanon}

Hizbullah's emergence is the result of numerous factors both local and regional. Having been formed in the midst of the Lebanese Civil War, and largely as a result of the various factors therein, we need to examine the modern political history that led to this civil war, as well as the internal and external forces that were exacerbating ethnic relations within the nation. Therefore, this chapter will examine Lebanon's modern history. Beginning at France's initial attempts to build a nation out of no less than seventeen separate numerous ethnic communities, we find that what eventually resulted was a confessional political system that never fully represented all members of Lebanese society. The insufficiency of this system inexorably led to civic strife between most of Lebanon's ethnic groups. Yet, the Shi'a Muslim, who were the most disenfranchised of all the ethnic groups in the state, were the exception, largely keeping to themselves due to their tendency to be apolitical. Interethnic tensions eventually devolved into a fifteen-year civil war that saw the virtual collapse of the government. Yet we will find that it was not this war per se that necessitated the creation of Hizbullah, but the concomitant invasion of Israel that was the final impetus for the galvanisation of Shi'a.

\section{The Emergence of Modern Lebanon}

The modern state of Lebanon is defined to a large degree by its geography. Located as it is on the edge of the Mediterranean Sea, it has proved historically favourable to trade and settlement. Furthermore, the coastal ranges of the Lebanon Mountains, the eastern Anti-Lebanon Mountains, and the Bekaa Valley in between these two ranges, have been seen as natural enclaves for many minorities seeking to escape persecution in other areas of the Middle East (see Figure 1). Thus, by the beginning of the twentieth century seventeen ethnic-religious groups were located in the region ${ }^{52}$.

52 These seventeen officially recognised sects were the four Muslim confessions (Sunni, Shi'a, Druze, and 'Alawi), the twelve Christian confessions (Assyrians, Syriac Catholics, 
These ethnic communities were primarily delineated by their religious denomination, and as such could be generally divided into either Christian or Muslim sects ${ }^{53}$. Each of these groups tended to dominate particular regions of Lebanon, with the Sunni and Shi'a Muslims predominately in the rural areas, and the Christian sects dominating the coastal areas and the mountain regions (see Figure 2). The Muslims, consisting mostly of both Sunni and Shi'a, naturally looked eastwards to their Islamic brethren for solidarity. However, the Christians, consisting of Maronite Catholics, Greek Orthodox, Greek Catholics, as well as Armenians, tended to look towards the West for their sense of identity ${ }^{54}$. These differing self-perceptions have resulted in divergent historical narratives with different perceived destinies. These divergent perceptions go some way in explaining the ethnic conflict that has resulted since the nation's formal inception ${ }^{55}$.

Syriac Orthodox, Chaldeans, Maronite Catholics, Melkite (Roman) Catholics, Greek Catholics, Greek Orthodox, Armenian Orthodox, Armenian Catholics, smaller Christian sects (mostly evangelicals)), and Jews. At the conclusion of the civil war Coptic Christians were officially recognised as another sect, bringing the total to eighteen. See Norton, A. R. (2007). Hezbollah: A Short History (1st ed.). Princeton: Princeton University Press, Note 1., p. 11. ${ }^{53}$ The Druze are not always considered part of Islam proper. Having emerged from a branch of Shi'a Islam in the $11^{\text {th }}$ century, they are often included with Shia in particular, or Muslims in general, due to their historical lineage. See Kliot, N. (1986). Lebanon - A Geography Of Hostages. Political Geography Quarterly, 5 (3), pp. 199-220 for a comprehensive demographic history of ethnic communities in Lebanon.

${ }^{54}$ Yiftachel, op. cit., p. 323.

55 Martin, C. (2012). Consociational Politics: The Influence of Hezbullah on the Stability of Sectarianism in Lebanon. Journal of Political Inquiry at New York University, 5 (5). 


\section{Figure 1}

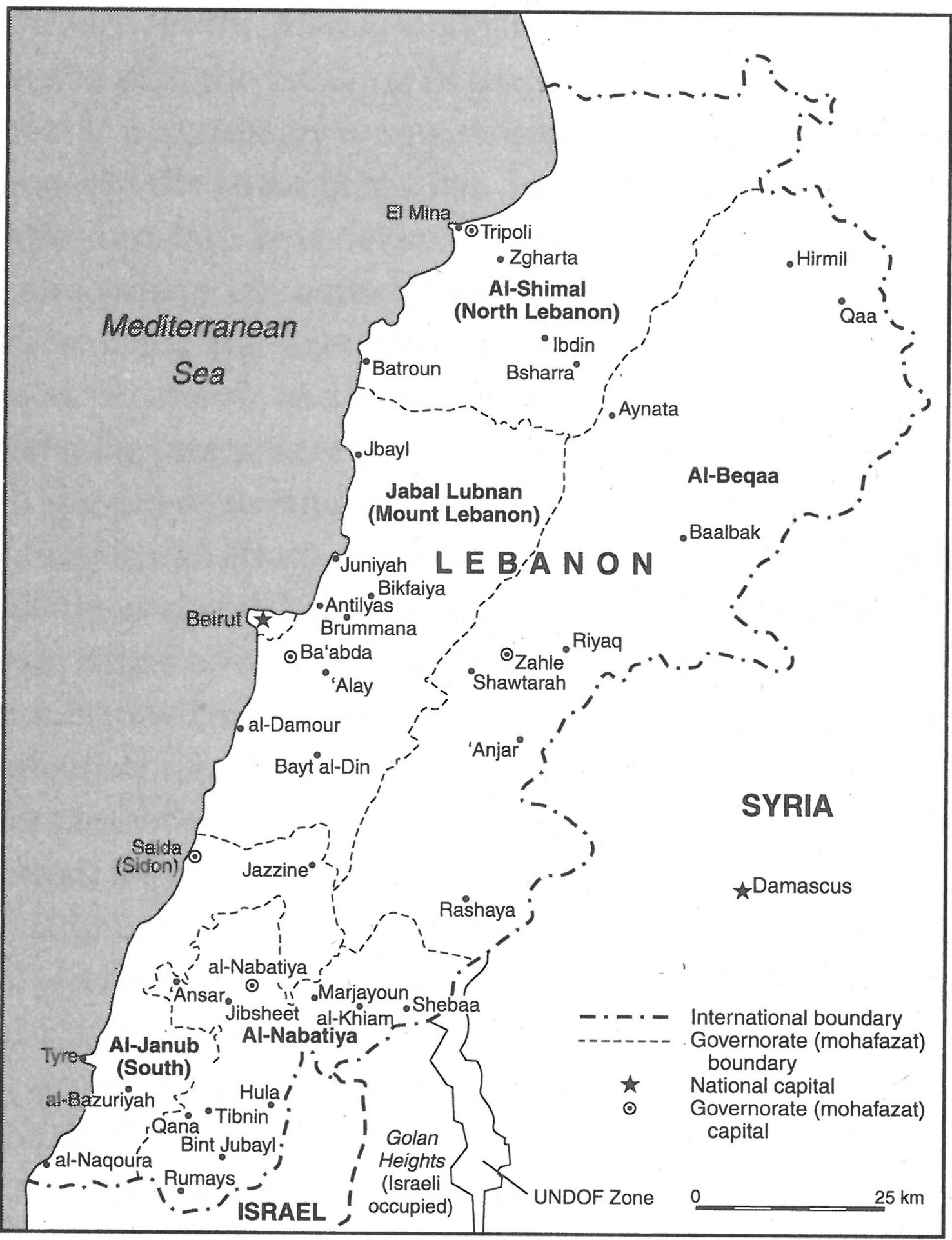

The major cities, towns, villages and administrative regions of Lebanon ${ }^{56}$.

${ }^{56}$ Adapted from Norton, Hezbollah: A Short History, p. 145. 
Figure 2

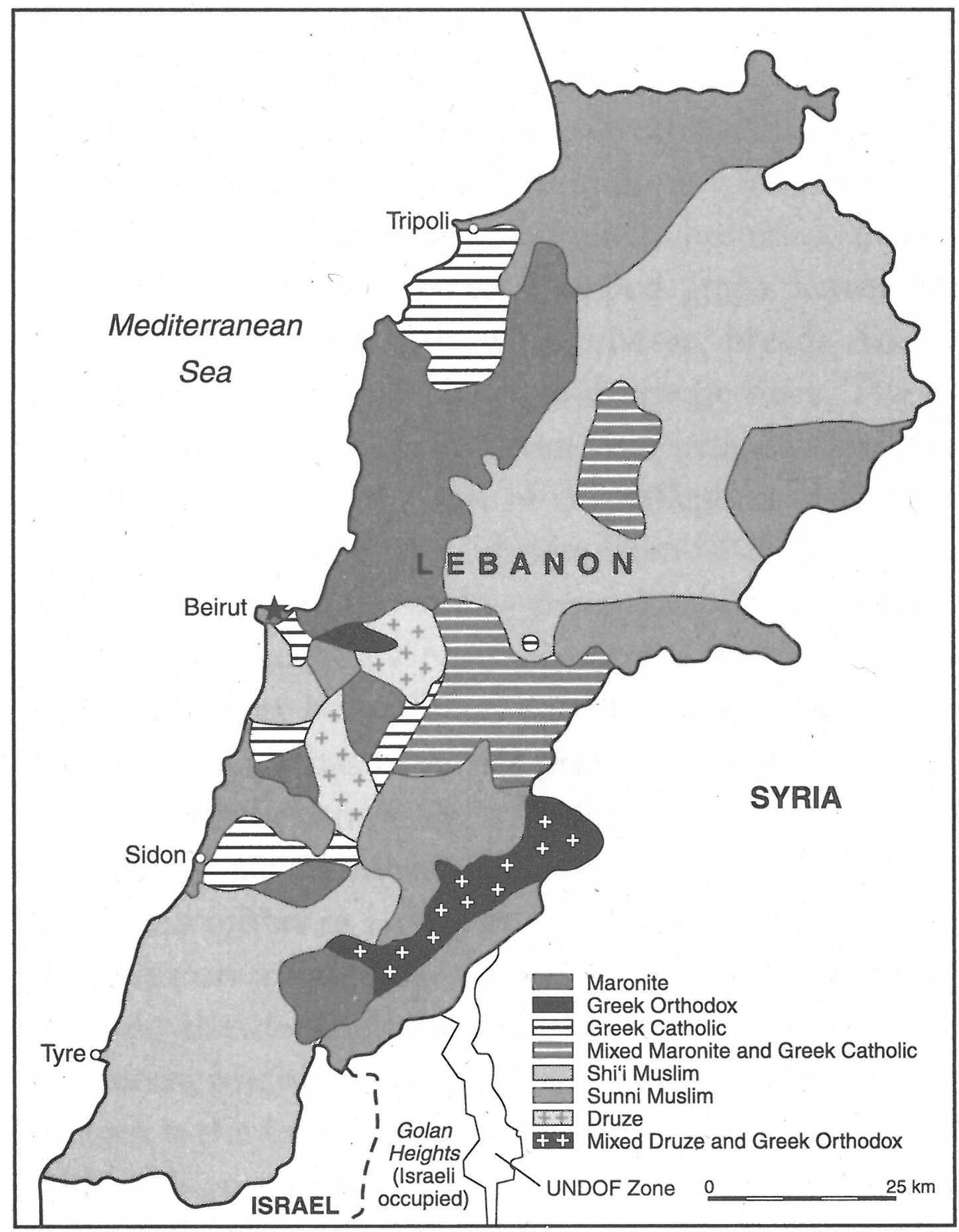

Demographic distribution of the major confessional groups within Lebanon ${ }^{57}$.

${ }^{57}$ Adapted from Norton, Hezbollah: A Short History, p. 1. 
Having been part of the Ottoman Empire for approximately 400 years Lebanon became part of the French Syrian and Lebanese mandate in 1918 following the end of World War One. With the 'acquisition' of Lebanon, France introduced two developments that were to have lasting influences on the state to this day: 1) A modern 'confessional' democratic system that was supposedly to be shared equally among all ethnic groups. This system purportedly guaranteed all citizens equal rights, with no stipulation that any particular executive, judicial or legislative position had to be occupied by any particular sect; and 2) the drawing of a new border that not only separated Lebanon administratively from Syria, but also brought new communities into the fold, namely Sunni and Shi'a Muslims ${ }^{58}$. That the Shi'a community accepted a new metropole in Beirut, turning away from the hitherto dominant nearby Damascus, was largely due to the French shrewdly offering Shi'a, for the first time, separate recognition from the region's majority Sunni Muslim population, and representation as such in the new confessional system ${ }^{59}$. This new found position of the Shi'a significantly differed from that under Ottoman rule, where they were essentially viewed as dissenting Muslims at best, heretical at worst, but nevertheless included administratively with, and subsumed by, the majority Sunni Muslim population.

The first president elected under this new constitution was Charles Dabbas in 1926, a Greek Orthodox, who won the election on a pan-Lebanese platform, as well as having the support of Muhammad al-Jisr, a Sunni Muslim who was speaker of the house ${ }^{60}$. At the end of Dabbas' second three-year term al-Jisr hoped to replace him as president. Suspecting that they might in fact have the majority, Sunni, Shi'a and Druze political elites had been agitating for a census to be taken since 192861. Adamant that he could

\footnotetext{
58 Cobban, The Making of Modern Lebanon, p. 61.

59 Ibid, p. 63.

60 Ibid. p. 64.

61 Firro, K. (2002). Inventing Lebanon: Nationalism and the State Under the Mandate.

London: I. B. Tauris \& Co Ltd, p. 116.
} 
garner Muslim support it was al-Jisr who pushed for a census to be taken in order to prove the supposed existence of this Muslim majority. Muslim elites were particularly active in mobilising their supporters, believing that participation was required to secure rights they perceived to be directly linked to their proportion of the overall population ${ }^{62}$. Christians on the other hand were wary of an overtly high representation by Muslims and therefore wished for emigrants to be included. This was because of a high percentage of emigrants being Christian. Contentions around the inclusion of emigrants continued with the correlation of results once the census had been taken. Yet Christians need not have worried, whether emigrants were included or not, Lebanon's first and, to this day only, census revealed that they were still the majority, albeit only just (see Figure 3). As we will see, it was on the basis of this census that the seeds for the continual failure of Lebanon's confessional system were sown, in that it informed the National Pact of 1942, which would eventually come to no longer reflect the demographic reality of Lebanon.

62 Ibid, p. 118. 


\section{Figure 3}

\begin{tabular}{lll}
\hline Confession & Population & Percentage \\
\hline Sunni & 181842 & 20.78 \\
Shi'a & 159782 & 18.26 \\
Druze & 56584 & 6.46 \\
\hline Total Muslims & $\mathbf{3 9 8 2 0 8}$ & $\mathbf{4 5 . 5 0}$ \\
\hline Maronites & 270938 & 30.96 \\
Greek Catholics & 55754 & 6.37 \\
Greek Orthodox & 93781 & 10.71 \\
Protestants & 7650 & 0.87 \\
Armenian Orthodox & 26294 & 3.00 \\
Armenian Catholics & 5919 & 0.68 \\
Syrian Orthodox & 2735 & 0.31 \\
Syrian Catholics & 2828 & 0.32 \\
Chaldean Orthodox & 548 & 0.06 \\
Chaldean Catholics & 190 & 0.02 \\
\hline Total Christians & $\mathbf{4 6 6 6 3 7}$ & $\mathbf{5 3 . 3 1}$ \\
\hline Jews & 3601 & 0.41 \\
Others & 6806 & 0.78 \\
\hline Total Non Muslim/Christians & $\mathbf{1 0 4 0 7}$ & $\mathbf{1 . 1 9}$ \\
\hline Total & 875252 & \\
\hline
\end{tabular}

1932 Census results as presented to the French authorities by the Lebanese Government ${ }^{63}$.

Regardless of what the outcome of the census indicated, al-Jisr's presidential aspiration was thwarted by French intervention; France suspended the constitution and appointed interim acting presidents. It was not till 1935 that France again allowed a president to be elected by the local Chamber of Deputies. Emil Eddé, a Maronite Christian, won this election by a single vote in $1936^{64}$. Around this same time, political forces in both France and Syria concluded talks whereupon both these countries entered into a 1936 treaty allowing for a phased withdrawal of direct French administration in Damascus ${ }^{65}$. Similar provisions were then put in place for Lebanon, which

${ }^{63}$ Adapted from Table 2. in Firro, op. cit., p. 120.

${ }^{64}$ Cobban, The Making of Modern Lebanon, p. 65.

65 Ibid, p. 66. 
were met with approval by both Christians and Muslims within parliament. However, out on the streets Muslims, who sensed a definitive break from Syria, and only an ostensible independence from France, launched public demonstrations. The Maronite community, in defence of the treaty terms with France, responded by forming paramilitary groups and, in a precursor of things to come, fighting broke out in the suburbs of Beirut ${ }^{66}$. This fierce Maronite nationalism, and their desire for definitive independence from Syria, eventually coalesced into political activism and the formation of the Kata'ib (better known in the West as the Phalanges) political party by the end of $1936^{67}$. Divisive sectarianism had started to make inroads into Lebanese politics.

With the outbreak of World War Two in 1939, external forces decided the internal aspirations of the Lebanese people. The 1936 treaty with France had promised independence by the end of 1939, however in the interests of France's attempts at establishing and retaining hegemonic power within the region the constitution was again suspended ${ }^{68}$. With the Germany-backed Vichy regime in place in France, a new pro-Vichy general was appointed to the French high Commission in Beirut in December of 1940. Six months later, with the arrival of the Allied forces in Syria and Lebanon, a 'Free French' administration was then installed. In keeping with the 'Free French' commitment to Syria and Lebanon's independence, a return was made to the obligations of the 1936 treaty. At the urging of both United States of America and Britain, who had expressed no apparent desire in either Syria or Lebanon, General de Gaulle, the leader of the Free French forces, finally declared Lebanese independence on the 26 November $1941^{69}$.

\footnotetext{
66 Ibid, p. 67.

67 Hudson, M. C. (1968). The Precarious Republic: Political Modernization in Lebanon. 1968:

Random House, p. 142.

68 Cobban, The Making of Modern Lebanon, p. 69.

${ }^{69}$ Abraham, op. cit., p. 110.
} 


\section{The National Pact and the Formation of a Confessional Government}

Lebanon finally gained full independence from France in 1943, although this initial independence was in fact nominal, as France did not fully leave the country until late in $1946^{70}$. The so-called National Pact guided the formation of the first truly independent Lebanese government. This pact was essentially a 'gentlemen's agreement' between Sunni and Maronite elites $^{71}$. It divided political positions along the confessional lines based on the assumed demographics of the country at the time (which largely matched those of the 1932 census) ${ }^{72}$; Maronites were granted the Presidency, Sunni Muslims the Prime Minister's position, and Shi'a were given the role of the Speaker of the House ${ }^{73}$. An ostensibly consociational democracy emerged in an attempt to stabilise perhaps one of the most pluralistic states in the world ${ }^{74}$.

Although this National Pact was unwritten it was reinforced by a significant political community within Lebanon that was relatively more organised and entrenched than was usually the case in many new post-colonial countries in a similar position ${ }^{75}$. A system referred to as iqta where leadership roles were granted due to land ownership, or through tax-raising responsibilities ${ }^{76}$, had in fact been in existence between the different confessions within the Lebanese interior for the last 350 years. The constitution introduced in 1926 had essentially codified much of this political cooperation that was already taking place ${ }^{77}$. Yet, despite this relative political sophistication, Lebanon was still beset by a 'phantom

\footnotetext{
70 Cobban, The Making of Modern Lebanon, p. 77.

${ }^{71}$ Harik, op. cit., p. 17.

72 The assumption was that the demographics had not changed significantly since the census of 1932. This was the first and last census ever taken in Lebanon; see Kliot, op. cit., p. 207.

73 Saouli, A. (2006). Stability Under Late State Formation: The Case Of Lebanon. Cambridge Review Of International Affairs , 19 (4), p. 706.

74 Yiftachel, op. cit., p. 323.

75 Cobban, The Making of Modern Lebanon, p. 77.

76 Shanahan, op. cit., p. 17.

77 Cobban, The Making of Modern Lebanon, p. 76.
} 
feudalism' that was inherited from its time under Ottoman rule ${ }^{78}$. This was particularly noticeable in the continuance of the $z u^{\prime} a m a^{79}$ system, a clanbased system of social ordering centred around family allegiances and which favoured a preference for client based patronage ${ }^{80}$. Traditionally, particularly so in the rural areas, za'im were significant landholders. But the ownership of land was not always necessarily a requirement for a person to become a notable figure within the zu'ama system. Often it was enough to own large amounts of capital, or have a traditionally aristocratic claim to rule. This was particularly the case for za'im within the urban areas of Lebanon ${ }^{81}$. And while parliamentary elections would be held on schedule until 1975, a Western style democracy never really took hold; liberal ideals of democracy continually came up against the historical allegiances of clan and family ${ }^{82}$. Thus, regional power elites essentially become the clients of elites at the national level, and attempts at power sharing at the national level quickly took on the visage of inter-sectarian competition.

At this time, Lebanon was not the only country in the region emerging from colonialism; Egypt, Jordan and Syria were also experiencing newfound independence, which in turn fostered mutual identification and the growth of pan-Arab idealism. Arab nationalism within Lebanon, which tended to be more marked in the Muslim communities ${ }^{83}$, was ready to embrace this idea. The particular Lebanese Muslim interpretation of this manifested itself as a desire to return to a union with Syria. For its part, Syria had always, and still did, retain the idea that Lebanon was essentially a part of a greater Syria ${ }^{84}$.

\footnotetext{
78 Abraham, op. cit., p. 123.

${ }^{79} \mathrm{Zu}$ 'ama (sing. $\mathrm{Za}$ 'im) is Arabic for 'leader', particularly that of a political nature.

80 Shanahan, op. cit., p. 37.

81 Cobban, The Making of Modern Lebanon, p. 78.

82 Ibid, p. 78.

83 Salibi, op. cit., p. 185.

84 Cobban, The Making of Modern Lebanon, p. 80.
} 
Despite this, external power influences upon Lebanon were, at the time, at their lowest ebb; Britain's post-war mood was far from imperialistic ${ }^{85}$, France was focussed on post-war rebuilding, and Syria was subsumed and occupied from the late 1940's onwards with a series of coups d'état ${ }^{86}$. Lebanon was, on the whole, left alone to contend with its own internal problems. That Lebanon's transition to independence was relatively unproblematic is perhaps more because of a serendipitous prosperity rather than because of the successful implementation of its confessional political system. It's new found affluence was in part because of the turmoil that surrounded it, in that large amounts of Arab capital investment that flowed into the free markets of Beirut were made in an attempt to escape the region's other disrupted centralist economies ${ }^{87}$. With its industrialised economy, highly trained workforce, free press, prestigious universities and relatively liberal life-style, Lebanon become the cultural centre on the Arab World ${ }^{88}$. Lebanon entered it's so called 'golden period', earning its superficial moniker as 'the Switzerland of the Middle East', just as Beirut earned the even more facile title of 'the Paris of the Middle East'89; an analogy one can safely assume was based more on its sparkling waterfront yacht clubs, cafes, and their clientele, than on its poor western and southern suburbs. Yet this comparatively calm and prosperous appearance belied continual ethnic divisions that had never really gone away. Political power continued to be shared by the two main sects, the Maronites and the Sunni, as economic and social disparities steadily grew behind the façade that Lebanon was presenting to the world.

It is no surprise that Lebanon's prosperity did not flow to all sections of society; as a tight alliance between both the business and political elites often meant that the public interest was secondary. Thus by 1959 approximately 50 per cent of the population was defined as poor, 30 per

\footnotetext{
85 Ibid, p. 81.

86 Ibid, p. 83.

${ }^{87}$ Ibid, p. 81.

88 Salibi, op. cit., p. 191.

89 Fouad, A. (1981, April 20). Lebanon: Myth and Reality. The New York Times , p. 19.
} 
cent as having an average income, 14 per cent as affluent, and 4 per cent as rich. This translated into approximately 4 per cent of the population receiving 32 per cent of Lebanon's total GDP, while 82 per cent only shared 40 per cent ${ }^{90}$. And while ethnic community had never necessarily been closely correlated with social class, Shi'a Muslims tended to be concentrated at the bottom of the income scale. As Shi'a traditionally tended to be unskilled and/or agricultural workers, and situated as they were in the impoverished suburbs of Beirut as well as the disadvantaged regions of the Bekaa Valley and Southern Lebanon, it can be confidently supposed that they were worse off than most other groups, particularly the Christian communities ${ }^{91}$.

This disparity between Christians and Muslims in general was also apparent in the education system and its outcomes. Up until the 1960's the education system in Lebanon was mostly private. Each confession developed its own education system and curriculum for their own communities. The education system was particularly comprehensive and competent within the Christian communities. Because of this the Christian communities mostly received private tuition whereas Muslims were destined to attend public schools, where they existed ${ }^{92}$. As these private schools relied heavily on the patronage of political elites, literacy rates often did correspond to socioeconomic class. Literacy rates within Lebanon were generally low for all confessions, yet they were even lower for Muslims, and Shi'a in particular; as of 1958 as much as 79 per cent of Shi'a Muslim were illiterate, as were 59 per cent of Sunni, 51 per cent of Druze, 50 per cent of Greek Orthodox, and 42 per cent of Maronite ${ }^{93}$.

\footnotetext{
${ }^{90}$ Kliot, op. cit., p. 68.

91 Ibid, p. 69.

92 Ibid, p. 59.

93 Ibid, p. 58.
} 
In addition to the socioeconomic disparities, continued sectarian hostility became even more marked following President Chamoun's failure to support Egypt in the Suez Crisis of $1956^{94}$, leading to what became, in essence, Lebanon's first civil war in 1958. These enmities, exacerbated by the continual Christian propensity to embrace a Western orientation, directly come into confrontation with the predominantly Muslim fostered Arab nationalism ${ }^{95}$. Chamoun's failure to break ties with the western states that had attacked Egypt, as well as his indifference to joining the new unification of Egypt and Syria into the United Arab Republic (UAR), sparked off violent demonstrations by Muslims in the main centres of Lebanon. These demonstrations finally descended into a civil war, with Sunni Muslim opposition forces quickly gaining control of regional centres. Beirut, in a potent omen of things to come, quickly splintered into Christian and Muslim controlled halves. Chamoun accordingly believed that the civil war was being encouraged by the UAR. This, as well as his fear of following the same fate as his recently disposed ally, King Faisal of Iraq ${ }^{96}$, resulted in him evoking the Eisenhower Doctrine ${ }^{97}$ and calling upon the United States of America for assistance ${ }^{98}$. America duly responded and the civil war was eventually brought to an end through the intervention of 15,000 American troops ${ }^{99}$.

\footnotetext{
94 In late 1956, following Egyptian president Gamal Abdel Nasser's decision to nationalize the Suez Channel, Israel, France and Britain invaded Egypt ostensibly to regain control of the channel but also to remove Nasser from power. Chamoun, in a blatant display of his pro-Western leanings, disapproved of Nasser's nationalization of the channel, and refused to sever diplomatic ties with the Western countries involved. The United Nations, with assistance from both the Soviet Union and the United States ultimately convinced all aggressing parties to withdraw.

${ }^{95}$ Salibi, op. cit., p. 197

${ }^{96}$ The republican movement in Iraq, spurred on by the formation of the UAR and the events of the Suez Crisis, killed King Faisal II as well as several members of his family on the $14^{\text {th }}$ of July 1958. Iraq then became a republic ending the 37-year monarchy. See Khadduri, M. (1969). Republican Iraq: A Study in Iraqi Politics since the Revolution in 1958. London: Oxford University Press.

${ }^{97}$ The 1957 Eisenhower Doctrine declared that the United States of America would provide economic and military aid, as well as military intervention if needed, to countries in the Middle East to prevent revolution and the spread of communism. See Hahn, P. (2006). Securing the Middle East: The Eisenhower Doctrine of 1957. Presidential Studies Quarterly, $36(1)$, p. 38.

${ }_{98}$ Cobban, The Making of Modern Lebanon, p. 89.

${ }^{99}$ Ibid, p. 90.
} 
Having weathered this crisis, Lebanon entered another relatively quiet period. President Chamoun had been eventually replaced with Fuad Shibab. Shibab appeared more enlightened about the internal problems of Lebanon during his six years in power, and is now considered one of Lebanon's more moderate and successful presidents ${ }^{100}$. Having realised the multitude of dichotomies that prevailed in Lebanon between the rich and poor, Christian and Muslim, as well as their correlation between the urban and rural, Shibab attempted to overcome traditional leadership arrangements and sectarian divisions in a drive towards a more national perspective ${ }^{101}$. However, external forces were soon to come into play that would stymy Shibab's attempts at improving the situation in Lebanon.

\section{The Lebanese Civil War}

Fifteen years of civil war in Lebanon saw the country used as an arena for contesting internal actors as well as external powers. Israel, Palestinians, Iran, Syria, The United States of America, France, The United Kingdom, as well as a multitude of internal Lebanese factions found themselves involved in an internecine war that was as much about sovereignty, territory, and identity as it was about ideology. At the end of the war in 1990, the Palestine Liberation Organisation (PLO) had been expelled from Lebanon, Israel occupied a large part of Southern Lebanon, and Syria essentially occupied the remainder. As such, there were no winners and nothing had changed for the better; the initial conditions that led to the chaos were essentially still in existence and were in fact exacerbated; society was now more heterogeneous than ever, and a numerically preponderant Muslim community, particularly that of the Shi'a, was still disadvantaged across the framework of political institutions. Lebanon was still an institutionally weak country, it was still politically divided along confessional lines and it therefore still teetered precariously close to further sectarian violence.

\footnotetext{
100 Shanahan, op. cit., p. 70.

101 Ibid, p. 99.
} 
Accounts of the civil war often place the presence of Palestinians in Lebanon at the heart of its inception ${ }^{102}$. While it is fair to say that their presence certainly had a part to play, the events of 1958 had already demonstrated that sectarian divisions within Lebanon were already fraught enough for civil strife to spiral out of control ${ }^{103}$. Sufficient conditions were already in existence; the arrival of Palestinians in increased numbers just added further volatility. Palestinians had in fact been in Lebanon in sizable numbers since 1948. With the Arab armies' defeat in the Six Day War of $1967^{104}$ and the 1970 'Black September' events in Jordan ${ }^{105}$, further numbers flowed into Lebanon in general and Beirut in particular. The Jordanian aggression of 'Black September' had particularly targeted the fedayeen, the Palestinian militia106, who quickly establish another base in Lebanon. Finding local support from Palestinian refugees already in Lebanon, as well as from the greater Arab community in general, the fedayeen were ultimately able to resist the Lebanese army's attempts to suppress their activities ${ }^{107}$. With the PLO, and its military cadre, now firmly ensconced in Beirut, and the 'Cairo Agreement' of 1969 regulating and legitimatising their existence there, they then found themselves with a new staging base with which to attack Israel ${ }^{108}$. Retaliatory Israeli attacks on Lebanon, with the objective of turning Lebanese against the Palestinians, in

\footnotetext{
102 Cleveland, W. L. (2004). A History of the Modern Middle East. Boulder, Colorado: Westview Press, p. 373.

103 Brynen, R. (1989). PLO Policy in Lebanon: Legacies and Lessons. Journal of Palestinian Studies, 18 (2), pp. 50.

${ }^{104}$ Following high tensions, this short war fought between Israel against Egypt, Jordan and Syria, ultimately culminated in a resounding defeat of the Arab forces. This defeat indicated to the Palestinians that they would need to assume responsibility for liberating their homeland, and essentially transformed the hitherto purely administrative Palestinian Liberation Organisation (PLO) into an independent resistance organisation. See Cleveland, op. cit., p. 359.

${ }^{105}$ Having established a base of operations inside Jordan from which to stage continuing attacks on Israel, the Popular Front for the Liberation of Palestine (PFLP) had increasingly flouted their disregard for Jordanian jurisdiction and the authority of King Hussein. Following the PFLP's hijacking of four civilian aircraft, King Hussein ordered the Jordanian army to attack the Palestinian refugee camps, and this effectively drove the Palestinians from Jordan, large numbers invariably migrating to Lebanon. See Cleveland, op. cit., p. 362. 106 Hinchcliffe, P., \& Milton-Edwards, B. (2009). Jordan: A Hashemite Legacy. (2nd Edition). New York, Routledge, p. 46.

107 Brynen, op. cit., p. 50.

${ }_{108}$ Cobban, The Making of Modern Lebanon, p. 109; Saseen, S. M. (1990). The Taif Accord and Lebanon's Struggle to Regain its Sovereignty. American University Internatiional Law Review , 6 (1), p. 60.
} 
fact only consolidated Lebanese and Palestinian solidarity. This was particularly the case with the Shi'a Muslims in the Southern Region of Lebanon who also bore the brunt of Israeli aggression ${ }^{109}$. However, while it hardly required this new community to plunge the country into civil strife, Muslim solidarity with the Palestinians further exacerbated internal distrust and conflict. Increasing Israeli attacks on Palestinian bases within Lebanon eventually eroded the political authority and legitimacy of Lebanon's political institutions ${ }^{110}$, and the already inadequate management of ethnic conflict under the failing National Pact, completely broke down ${ }^{111}$. Simmering political rivalry between Christian and Muslim groups quickly descended into urban warfare within Beirut. Battlelines were drawn between PLO controlled predominantly Muslim West Beirut and the Christian Phalange controlled East Beirut. This dualistic conflict quickly engulfed greater Lebanon, and eventually descended into a multilateral civil war. Mass internal migration significantly altered the internal demographics of Lebanon; Christians largely left the northern and southern regions of the nation, as well as the Bekaa Valley, and either moved into East Beirut or left the country altogether ${ }^{112}$. Large regions of the nation become much more ethnically homogenous, and these regions essentially became 'no-go' areas for those from differing confessions ${ }^{113}$. Under these opposing tensions the already weak authority of the Lebanese government was subsumed by the rule of competing militias, and Lebanon entered fifteen years of conflict.

By 1976 civil warfare had engulfed large portions of the nation; southern Lebanon was still relatively devoid of sectarian violence, but was to ultimately endure the external aggression of Israel. Eventually summits in both Cairo and Riyadh resulted in The Arab League, in one of its first

\footnotetext{
109 Ibid, p. 61.

110 Abraham, Lebanon in Modern Times. Lanham, p. 135.

111 Saseen, S. M. (1990). The Taif Accord and Lebanon's Struggle to Regain its Sovereignty.

American University Internatiional Law Review , 6 (1), p. 61.

112 Kliot, op. cit., p. 210.

113 Owen, R. (1984). The Lebanese Crisis: Fragmentation or Reconciliation? Third World

Quarterly, 6 (4), p. 943.
} 
interventionist decisions, establishing the 30,000 strong Arab Deterrent Force (ADF), whose role was to enforce the Cairo Agreement ${ }^{114}$. This force, consisting mainly of Syrian troops, entered Lebanon ostensibly on a peacekeeping mission ${ }^{115}$. As a result Syria, which at this time still did not recognise Lebanese sovereignty, found itself to be exactly where it wanted to be. The mandate for the ADF was eventually extended in 1979, and all but the Syrian troops departed. The supposed ADF essentially became a Syrian occupying force that then expanded in number and that would then occupy Lebanon, excepting the Southern region, for the next 27 years ${ }^{116}$.

By 1978 the PLO and the Palestinian community had relocated to Southern Lebanon effectively establishing a state within a state. Up till now this area, which was predominantly Shi'a Muslim and reasonably homogenous, had remained relatively untouched by the sectarian violence that had played out mainly in Beirut and the northern regions of Lebanon ${ }^{117}$. However, this was about to change; with the new Palestinian threat, situated as it was on the northern border of Israel, their security concerns for settlements in their northern region was increased. Following attacks by the Palestinians, Israel invaded Lebanon for the first time in 1978, pushing as far north as the Latani River. This invasion successfully forced the PLO, and in addition large numbers of Shi'a Muslims, north of the Latani River, into the already disrupted and overpopulated suburbs of Beirut ${ }^{118}$.

As a result of this invasion the Security Council of the United Nations passed Resolutions 425 and $426^{119}$. These two resolutions, taken together, called for an immediate ceasefire, called on Israel to withdraw its troops from Southern Lebanon, and called for Lebanon's sovereignty to be restored. The

\footnotetext{
114 Saseen, op. cit., p. 63.

115 Rabinovich, I. (1986). The War For Lebanon: 1970-1985. Ithaca, New York: Cornell

University Press, p. 56.

116 Saseen, op. cit., p. 63.

117 Cobban, The Making of Modern Lebanon, p. 158.

118 Cleveland, op. cit., p. 387.

119 The United Nations (UN). (1978, March 19). Security Council Resolutions. Retrieved December 5, 2012, from United Nations Security Council:

http://www.un.org/ga/search/view_doc.asp?symbol=S/RES/425(1978)
} 
United Nations Interim Force In Lebanon (UNIFIL) was established to oversee Israel's withdrawal and the implementation of the other requirements of the resolutions ${ }^{120}$. Israel ultimately withdrew that same year, but not before handing conquered territory to the South Lebanon Army (SLA), a Christian militia allied with Israel.

However, In 1982 Israel again invaded Lebanon following the attempted assassination in London of Shlomo Argov, Israel's ambassador to the United Kingdom, for which Israel blamed the $\mathrm{PLO}^{121}$. On this occasion Israel was intent on both defeating the Syrians, as well as driving the PLO not just from Beirut but also from Lebanon completely ${ }^{122}$. In response the United Nations General Assembly condemned the invasion and the United Nations Security Council passed Resolution 508123. This new resolution was more strongly worded and this time demanded Israel withdraw from Lebanon, as well as calling for an end to hostilities between Israel and the PLO ${ }^{124}$. Resolutions 425 and 426, much of which had been rendered redundant by subsequent events, were recalled, although UNIFIL was to continue with its mandate. Israel and Lebanon finally signed an agreement 1983 for Israel to withdraw, although this retreat was not actually actioned until 1985, and then Israel still retained approximately 523 square kilometres (325 Square miles) in Southern Lebanon as a buffer zone. This area comprised approximately $8 \%$ of Lebanon's territory and contained approximately 200,000 Lebanese citizens $^{125}$, most of whom were Shi'a Muslim ${ }^{126}$. Israel would not withdraw from this area until 2000, and then only as a result of Hizbullah aggression. As will be examined in the next chapter it was this very invasion and occupation that played a large part in Hizbullah's formation.

\footnotetext{
120 Cobban, The Making of Modern Lebanon, p. 162.

${ }^{121}$ Abraham, Lebanon in Modern Times, p. 151.

122 Saseen, op. cit., p. 64.

123 The United Nations (UN). (1982, June 5). Security Council Resolutions. Retrieved December 5, 2012, from The United Nations Security Council: http://www.un.org/ga/search/view_doc.asp?symbol=S/RES/508(1982)

${ }^{124}$ Allain, J. (2004). International Law in the Middle East: Closer to Power than Justice. Aldershot, England: Ashgate Publishing Limited, p. 144.

125 Diehl, J. (1989, October 20). Israel Seems Ready To Linger in S. Lebanon. The Washington Post , p. A33; cited in Saseen, op. cit., p. 65.

126 Norton, Amal and the Shi'a, p. 120.
} 


\section{The Taif Accord}

From 1982 until the end of that decade the various militias within Lebanon continued to fight each other. In addition to these warring factions, external forces, particularly Syria, Iran (in its support of Shi'a Muslim militias), and Israel (with its continual occupation of the South and alliance with the Christian Phalange) added to the already complicated shifting alliances ${ }^{127}$. Syria, with the largest occupying force in the country, made numerous attempts at formulating agreements with a view to resolving the conflict. However, as these were fundamentally centred on an implicit integration with Syrian institutions, Lebanese forces, particularly those of the Maronites and other Christian groups, largely resisted them ${ }^{128}$.

That the fighting continued unabated, and resisted any political solution was largely because the various ethnic communities were unable to agree on what reforms should and could take place, and that would be mutually agreeable to all ethnic and religious groups. The demographics of Lebanon had changed significantly not only since the census of 1932, but also since the outbreak of the civil war. Further to this, the geographic distribution and concentration of the differing ethnic communities in particular regional centres had also under gone significant changes. Because of this, the allotment of seats in parliament no longer proportionally reflected this new demographic reality. Muslims in general, and Shi'a Muslims in particular, were now in the majority ${ }^{129}$, and it was no surprise that they now insisted that this fact be reflected in any constitutional reforms. However, the Maronites, as well as other Christian groups, deemed any reforms that incorporated these demographic changes as unpalatable ${ }^{130}$. In addition to all this, the Druze, as always had been the case, still insisted that the constitution reflect their influence and importance not necessarily their

\footnotetext{
127 Cleveland, $A$ History of the Modern Middle East, p. 390.

128 Abraham, Lebanon in Modern Times, p. 159.

129 Cleveland, op. cit., p. 390.

130 Ibid, p. 390.
} 
proportion of Lebanese demographics, which was only about six per cent of the population ${ }^{131}$.

Despite the near anarchy that had descended upon Lebanon since 1975, the parliamentary process largely continued unabated. While there were no general elections within Lebanon during the years of the civil war, the cabinet, surprisingly considering the situation, continued to meet and to elect the president up until 1988132. However, the parliament buildings were located on what came to be known as the 'Green Line' which marked the division between the Christian and Muslim halves of Beirut, and which was also the scene of some of most intense urban fighting of the whole civil war. Any attempts to form new cabinets or to formulate legislation were almost always thwarted by sniper fire or outright urban warfare ${ }^{133}$. In any case, governmental authority had largely been reduced to token gestures, and meaningless declarations.

However, it was a particularly ominous breakdown of Lebanese parliamentary process that proved the final impetus to getting the various Lebanese factions to accept concessions and arrive at a resolution. In 1988, on the expiry of his presidency, Maronite Amin Gemayel, appointed another interim cabinet headed by a fellow Maronite as acting Prime Minister, army commander Michel Aoun. This clearly went against the National Pact and infuriated the current, constitutionally legitimate Sunni Prime Minster, Salim al-Hus, who refused to give up his post ${ }^{134}$. Thus Lebanon, which up to this point had against all odds retained a relatively consistent political process despite the civil war, was now faced with two competing governments; namely the military government of Aoun and the civilian

\footnotetext{
131 Saseen, op. cit., p. 69.

132 Ibid, p. 58.

133 Owen, op. cit., p. 944.

134 Cleveland, op. cit., p. 391.
} 
government of al-Hus ${ }^{135}$. The existence of two governments threatened to definitively divide Lebanon into an apparently northern Christian half and Muslim South, and set off a new wave of sectarian violence. Further to this, there had been a slow but growing public intolerance towards the continual inter-sectarian warfare that had destroyed the country, and a growing push for a decisive civil resolution to it. This had already resulted in massive cross-communal public demonstrations, starting in 1987, that were directly aimed at the militias, and were intended to inform them that they were no longer held to be the solution, as no one militia had the ability to conclusively win the war. This, and the looming spectre of renewed violence, was enough to convince the Lebanese political elites to make a renewed concerted effort in find a resolution to the conflict ${ }^{136}$.

Recognising this significant change in attitude within Lebanon, the Mediation Committee of the Arab League, which consisted of the current rulers of Algeria, Morocco and Saudi Arabia, proposed a series of meetings in Saudi Arabia with a aim to decisively bringing Lebanon's civil war to an end $^{137}$. These meetings culminated in sixty-two Lebanese politicians beings summonsed to the town of Taif in Western Saudi Arabia in September of 1989138. This group consisted of those from the 1972 parliament that had not since died (either from natural causes or killed) as well as others chosen to fill those vacant positions. In due course, concessions were made and an accord was formulated in October 1989 that, while not completely satisfactory to all parties, was seen as a working template to a way forward. This agreement was essentially an updated version of the 1943 National Pact ${ }^{139}$. To varying degrees of success, it attempted to reflect Lebanon's new

\footnotetext{
135 Krayem, H. (1997). The Lebanese Civil War and the Taif Agreement. In P. Salem (Ed.), Conflict Resolution in the Arab World: Selected Essays (p. 482). Beirut: American University of Beirut.

136 Ibid, p. 391.

137 Saseen, op. cit., p. 67.

138 Cleveland, op. cit., p. 390.

139 Saseen, op. cit., p. 67.
} 
demographics, and in doing so gave Muslims a greater role within parliament.

The Taif Accord ${ }^{140}$ firstly endorsed reconciliation and political reform within Lebanon. The Sunni prime minister's powers were to be increased to the detriment of the Maronite president. In addition, the parliament membership was to be expanded from 99 to 108 seats, and these were to be shared evenly between Christians and Muslims, as opposed to the five to six ratio that had prevailed in favour of Christians previously. This ratio had purported to represent now out-dated demographics based on the 1932 census. Furthermore, the Shi'a speaker of the house's position was to be extended from one year to the life of that parliament, as well as obtaining a small increase in influence (by removing the executive branch's ability to pass urgent legislation without the approval of the parliament) ${ }^{141}$. The Shi'a Muslim political community considered this adjustment to be inconsequential and saw little gain in the constitutions new formulation. In fact, both Shi'a and Druze saw little benefit from this new accord. Both perceived it to be an agreement between their enemies, and that the Maronite and Sunnis had simply consolidated power and their positions ${ }^{142}$. The Shi'a, now the majority in Lebanon saw no justification in a SunniMaronite partnership that still denied them substantive political power, and perceived the partnership's rational to be about shoring up power against them ${ }^{143}$. Finally, the accord also stipulated that Lebanon's confessional political system should be phased out, although no timeline was stipulated nor were provisions provided. The accord was also silent how this was to be done ${ }^{144}$.

\footnotetext{
140 Also known as 'The Taif Agreement', 'Document of National Accord' or 'National Reconciliation Accord'. An online copy (English translation) of the document can be found at http://www.al-bab.com/arab/docs/lebanon/taif.htm

141 Hudson, M. C. (1997). Trying Again: Power-Sharing in Post-Civil War Lebanon. International Negotiation , 2, p. 113.

142 Abraham, A. J. (1996). The Lebanon War. Westport: Praegar Publishers, p. 177.

143 Saseen, op. cit., p. 69.

144 Hudson, International Negotiation, p. 113.
} 
In addition to these political reforms, the accord also reaffirmed Lebanon's sovereignty, and stated that its identity was "Arab in belonging and identity"145. This latter statement was a more strongly worded assertion of Lebanon's identity than that found in the National Pact of 1943. As such it alarmed portions of the Christian community who still orientated themselves towards Europe ${ }^{146}$. The accord then outlined that Lebanon had a "special relationship" with Syria ${ }^{147}$. This appeared contradictory because, in asserting Lebanese authority, the accord called all militia within Lebanon to be disarmed, and for this to be facilitated by Syria ${ }^{148}$ thereby perpetuating that country's continual presence within Lebanon's sovereign territory ${ }^{149}$. As well as their political losses, it was also because Syria had effectively been given this authority to affect the accord that Christian militia continued to resist. Thus, the Taif Accord failed to completely ameliorate all sectarian violence; sporadic fighting continued and it was not till early 1990 that civil fighting stopped and that a sense of peace finally descended upon Lebanon $^{150}$. By this time most militia had been disarmed with the exception of those dealing with the continual occupation of Southern Lebanon by Israel, that is, Hizbullah ${ }^{151}$ (which will be dealt with in more detail in the next section). However, any sense of normalcy was fragile; faced with fifteen years of continual ethnic violence members of the different ethnic communities had gravitated together geographically or at least had migrated back to their tradition regions of origin ${ }^{152}$. Lebanon was now more heterogeneous than ever, and the original conditions that led to civil war had only become exacerbated. As Kassim Ja'far, a Lebanese political

\footnotetext{
145 The Arab League. (2009, July 18). The Ta'if Accord. Retrieved January 12, 2013 from AlBab: http://www.al-bab.com/arab/docs/lebanon/taif.htm

146 Hudson, International Negotiation, p. 113.

147 The Arab League, op. cit.

148 Cleveland, op. cit., p. 390.

${ }^{149}$ Saseen, op. cit., p. 69.

${ }^{150}$ Abraham, The Lebanon War, p. 179.

151 Cleveland, op. cit., p. 392.

152 Ibid, p. 392.
} 
expert in political and strategic affairs, states: the civil war "ended as if it had never happened" 153 ; mistrust between confessional factions had increased and Lebanon was now occupied by two external powers, Israel and Syria.

The effects of the 1975 Civil War continue to reverberate through Lebanon today. It is out of these chaotic years that Shi'a found their political voice, which in turn lead to the formation of Hizbullah. And it is this organisation that has had the largest impact on Lebanon after the Taif Accord. This was to be particularly so once the organisation decided to enter into the political system that it had continually claimed to be corrupt. In the next part of this work, the particular factors that lead to Hizbullah's emergence will be examined.

153 Al Jazeera Satellite Channel. (2004). The Accord To End The War. War In Lebanon , Ep. 15 . Doha, Qatar. 


\section{The Emergence of Hizbullah}

Even though Hizbullah emerged from the midst of Lebanon's 15-year civil war, it is remarkably absent from many accounts of it. That this is so is because while the war certainly provided the circumstances for the organisations eventual emergence, it never the less is just the 'back ground'; Hizbullah's actual direct involvement in the sectarian violence at the time was minimal. Hizbullah from the start had a focused and singular goal; the expulsion of Israel from the nation, and the removal of Zionism from the region.

But to fully explain Hizbullah's formation requires an examination of the place of Shi'a in the region in general, within Lebanon in particular, and the specific circumstances that lead to their eventual politicisation. The Shi'a of Lebanon, like Shi'a throughout the immediate region, were minorities and relatively disenfranchised. They were traditionally inactive within politics and relied heavily on patronage through the zu'ama system of governance. Initial politicisation of Lebanese Shi'a took the form of secular political groups such as the Amal Movement. However, they were to find inspiration in the Shi'a Muslim Iranian Revolution, and through patronage from the minority Shi'a Alawi regime of Syria. With the invasion of Lebanon by Israel in 1982, Shi'a were galvanised into action and more revolutionary and militant Shi'a groups emerged. This loose conglomeration of groups eventually congealed into Hizbullah.

Hizbullah's revolutionary ideals meant that many were surprised, and worried, when it decided to tentatively participate in national politics in 1990. This was particularly so, as they had forged themselves a privileged position within the Taif Accord, by establishing themselves primarily as a resistance force, and effectively the last remaining militia from the days of the civil war. Thus Hizbullah began cultivating two dual, and often contradictory roles; that as a political party and that as a resistance group. These two roles will be examined separately in the subsequent chapter. 
This chapter will examine Hizbullah's initial appearance within Lebanon, and its initial attempts to legitimise itself therein.

\section{The Shi'a of Lebanon and the Emergence of Shi'ite Politics}

The demographics of Lebanon, as intrinsically tied to the legitimisation of the confessional system as they are, have long been a matter of fierce contention, and still continue to be so. Largely because of this, and as mentioned previously, no census has been undertaken in Lebanon since 1932. As a result, it is inherently risky to make any estimate of the current demographics of the nation. Nevertheless, most knowledgeable estimates now place the Shi'a population firmly in the majority ${ }^{154}$. The proportion of Shi'a that constitute the Lebanese population as of the early 1970's was estimated at 30 per cent and increasing155. Currently Shi'a are thought to approximately comprise at least 34 per cent of the population, easily making them the largest ethnic group within Lebanon ${ }^{156}$.

Immediately following Lebanese independence the majority of Shi'a were living in rural Lebanon, particularly the Bekaa Valley region and Southern Lebanon. The Shi'a in Lebanon, like their compatriots throughout the region, had adhered to a tradition of political quiescence ${ }^{157}$. This quietism had evolved from Shi'a's historical position as a minority in most nations. Mindful of this position, many Shi'a elites had advocated an apolitical stance for the sake of their survival ${ }^{158}$. Shi'a had largely withdrawn from political and social affairs and now resided "... forgotten in a dark corner of Arab

\footnotetext{
${ }^{154}$ Norton, Amal and the Shi'a, p. 17.

155 Tabbarah, R. B. (1979). Background to the Lebanese Conflict. International Journal of Comparative Sociology, 20 (1-2), p. 112.

156 Anecdotal data from the Lebanon Family Planning Association since the 1970's suggests that Shi'a Muslims have the largest rate of natural increase among the three largest confessional sects (Shi'a, Sunni and Christian), at 3.8 per cent per year. As of 2005 Shi'a Muslim are estimated to be $34 \%$ of the total Lebanese population making them the largest ethnic community in the country; See Faour, M. A. (2007). Religion, Demography, and Politics in Lebanon. Middle Eastern Studies , 43 (6), pp. 909-921; Chamie, J. (1976). The Lebanese Civil War: An Investigation into the Causes. World Affairs , 139 (3), p. 12.

157 Norton, Amal and the Shi'a, p. 19; Hamzeh, op. cit., p. 20.

158 Shanahan, The Shi'a of Lebanon: Clans, Parties and Clerics, p. 13.
} 
consciousness ${ }^{159 "}$. This, and the belief of the majority Sunni Muslim population that Shi'a had inexcusably deviated from the 'true' path of Sunni Islam $^{160}$ translated into historically political indifference by political elites at best, or political oppression at worst. Shi'a have customarily been underrepresented politically and therefore underprivileged throughout the region. Shi'a Muslims tended to be lacking in education and in financial resources. They also tended to significantly constitute the unskilled workforce and were stereotypically seen as "sub-proletariat 161 " and "untrustworthy ${ }^{162 " . ~ T h e ~ S h i ' a ~ M u s l i m s ~ o f ~ L e b a n o n ~ w e r e ~ n o ~ e x c e p t i o n . ~ W i t h ~}$ the majority of Shi'a living in rural areas and with the state spending practically nothing on rural development, Shi'a farmers struggled to support themselves and their families within the mainstream economy. Many Shi'a therefore prepared to risk the cultivation of opium poppies and hashish, which yielded more lucrative returns ${ }^{163}$. This tension in the rural South was then aggravated by the migration of Palestinians to these same regions following Israel's declaration of independence in 1948, with Palestinian's prepared to work for much less ${ }^{164}$.

From the 1960's onwards, the younger generation of Shi'a turned away from the traditional zu'ama style of politics, which they largely blamed for their continual marginalisation and which they thus perceived to have failed them ${ }^{165}$. Instead, they embraced other political movements such as the Lebanese Communist Party (LCP) and the Organisation for Communist Labour Action. These secular movements were mostly socialist in nature and were not always aligned with particular confessions. Despite this, Shi'a

\footnotetext{
159 Fuller, G. E., \& Francke, R. R. (2000, March). Is Shi'ism Radical? Middle East Quarterly , pp. 11-20.

160 Norton, Hezbollah: A Short History, p. 12.

161 Johnson, M. (1983). Popular Movements and Primordial Loyalties in Beirut. In T. Asad, \& R. Owen (Eds.), Sociology of "Developing Societies": The Middle East (pp. 178-194). New York: Monthy Review Press.

162 Norton, Amal and the Shi'a, p. 27.

163 Norton, Hezbollah: A Short History, p, 13.

164 Ibid, p. 14.

165 Sirriyeh, H. (2010). The Emergence of Hizbollah and the Beginnings of Resistance, 1982-

85. Israel and Hizbollah: An Asymmetric Conflict in Historical and Comparative Perspective (Kindle iPad Edition). (C. Jones, \& S. Catignani, Eds.) New York: Routledge, Paragraph 4. (Retrieved from http://www.amazon.com/)
} 
saw little compromise with Shi'a ideology. In fact, these organisations appeared to promise emancipation from old traditions that were seen as being bolstered by local Shi'a elites, in addition to the political elites at the state level ${ }^{166}$. However, because these movements were generally secular they were not always necessarily seen as furthering Shi'a interests. In addition to this, as most were also driven by the notion of Arab nationalism, many Shi'a also saw them as simply consolidating a Sunni hegemony ${ }^{167}$.

Because of this, by the early 1970's, and despite any assurances to be gained from a proportional increase in their numbers, Shi'a still lacked any effective political mobilisation or representation in the Lebanese parliament. At this time the parliamentary assembly consisted of 99 seats. Considering the existing ratio of 6 to 5 , this worked out to be 54 seats for Christians and 45 seats for Muslims. As of 197219 of these Muslim seats were allotted to Shi'a Muslims. If conservative estimates of the current demographics of Lebanon were applied, Shi'a Muslim would gain another 10 seats, bringing their allotment to 29. Further to this, if the assembly seats were divided evenly between Christian and Muslim then Shi'a would rightly gain a majority of the Muslim seats, as Sunni Muslims were now clearly in the minority at 20 per cent of the Lebanese population ${ }^{168}$. Any hypothetical gaining of seats in the parliament assembly by Shi'a Muslims would have been at the loss of Maronite Christians, who at the time had 30 seats, despite being clearly in the minority.

That Shi'a Muslims at the time were not more active in agitating for more seats in parliament is in no small part due an overt reliance on the aforementioned clan based zu'ama system that was particularly dominant within the Shi'a community, as well as the client based patronage method of governance that resulted ${ }^{169}$. In any case by the time the civil war commenced in 1975, due to fighting in Beirut and the northern regions of

\footnotetext{
166 Norton, Hezbollah: A Short History, p, 15.

167 Ibid, p. 15.

168 Norton, Amal and the Shi'a, p. 17.

169 Shanahan, The Shi'a of Lebanon: Clans, Parties and Clerics, p. 39.
} 
Lebanon, any potential political inroads into national politics outside of the zu'ama system had been largely stymied, if not shutdown, by the prevailing conflict. Parliament, when it did manage to assemble, was now largely ignored, and had effectively been replaced by the rule of the militias. Shi'a therefore largely retreated back into their communal groups for any help that might have been provided by a functioning national government. This was in fact the case with most confessions, many of which had retreated back into their religious groups in lieu of a functioning government ${ }^{170}$. Yet, despite the fact that the war was being fought mostly between other religious faiths, many young and alienated Shi'a found joining militias an alternative to the perceived futility of their lives ${ }^{171}$. As they were relegated to being basic infantrymen, 'work' as part of a militia was relatively well paid but was particularly lethal for Shi'a; ultimately more Shi'a died in the civil war that from any other religious group ${ }^{172}$.

Shi'a were ready to gravitate around any leader that would promise deliverance from their hopeless conditions in Lebanon. Such a leader was found in Imam Musa al-Sadr, an imam born and educated in Iran. Musa alSadr, whose ancestors had originated from Southern Lebanon, migrated to Lebanon in the late 1950's and was to play a significant role in the politicisation of Shi'a. In an attempt to improve the political advancement of Shi'a, and to separate that advancement from that of Sunni, al-Sadr helped establish the Supreme Islamic Shi'a Council in 1967, of which he was the first elected chair ${ }^{173}$. The establishment of the council primarily provided Shi'a with a national identity separate from their Sunni counterparts ${ }^{174}$, thereby also delineating Shi'a political aspirations from those of Sunni. Through the establishment of this council al-Sadr effectively become the leader of Lebanese Shi'a, as well as a prominent national political leader ${ }^{175}$.

\footnotetext{
170 Ibid, p. 106.

171 Norton, Hezbollah: A Short History, op. cit., p. 16.

172 Ibid, p. 17; Hamzeh, In The Path Of Hizbullah, p. 21.

173 Avon, D., \& Khatchadourian, A. T., op. cit., p. 212.

174 Hamzeh, op. cit., p. 20.

175 Norton, Hezbollah: A Short History, op. cit., p. 19.
} 
Relatively enlightened about the political realities of Lebanon, al-Sadr was a charismatic as well as pragmatic leader who realised the importance of interfaith dialogue within Lebanon ${ }^{176}$. Al-Sadr had also attempted to unite Palestinian concerns with those of Shi'a insofar as both groups were essentially 'disinherited'177. However, his attempts in this particular area would prove futile in light of eventual Palestinian brutalities against the Shi'a community ${ }^{178}$. Al-Sadr had also quickly realised the reformation of Lebanon's existing political institution was not the only solution ${ }^{179}$, as he also realised the subjugation of Shi'a was the result of not only the Maronite and Sunni hegemony prevailing in Lebanon ${ }^{180}$, but also from the prevailing Shi'a zu'ama system of patronage 181 , which al-Sadr quickly set about mobilising Shi'a politically against. He did this largely by adopting a 'grassroots' approach by improving local infrastructure wherever Shi'a were predominant. Al-Sadr adopted a politically moderate course and also established the 'Movement for the Disinherited' (Harakat al-Muhrumin) in 1974182. Emerging as a response to the lack of effective governance by the national parliament, this movement was fundamentally opposed to the zu'ama system and was more an activist movement than a political party proper ${ }^{183}$. Its fundamental purpose was to agitate for better social services for Shi'a.

In conjunction with the efforts of al-Sadr, the galvanisation of Shi'a in regards to themselves as a political entity was also the result of the unfolding civil strife consuming the country. Most political parties (all of which were invariably organised along confessional lines) quickly realised the need to reconfigure themselves as viable militias in order to effectively

\footnotetext{
176 Avon, D., \& Khatchadourian, A. T., op. cit., p. 212.

177 Ibid, p. 15.

178 Ibid, p. 18.

${ }^{179}$ Akho-Rashida, A. M., \& Barari, H. A. (2010). The Pragmatic and The Radical. Israel and Hizbollah: An Asymmetric Conflict in Historical and Comparative Perspective (Kindle iPad). (C. Jones, \& S. Catignani, Eds.) New York: Routledge., Paragraph 8. (Retrieved from http://www.amazon.com/) 180 Norton, Hezbollah: A Short History, p. 19.

181 Shanahan, The Shi'a of Lebanon: Clans, Parties and Clerics, p. 107

182 Also referred to as the 'Movement for the Deprived' or 'Movement for the Dispossessed'. Hamzeh, op. cit., p. 21.

183 Shanahan, The Shi'a of Lebanon: Clans, Parties and Clerics, p. 107.
} 
participate in the civil war. The Shi'a, on the other hand, already recognised their militia potential. While not having previously formed any significant militia organisation, they conversely recognised that to do so was a much more expedient strategy than the need to formulate some form of political representation ${ }^{184}$. These two potentialities were to be quickly realised within the one organisation; with the outbreak of the civil war the Movement for the Disinherited was armed and reestablished itself as a politico-militia that was to become known by its acronym, Amal (transliterated as Afwaq al-Muqawamah al-Lubnaniyyah), which also meant 'hope' in Arabic ${ }^{185}$. Initially a reformist movement, Amal sought betterment and political representation for all Lebanese, not necessarily just Shi'a, although they were its preponderant support base ${ }^{186}$. As such Amal attempted to present itself as secular albeit guided by Shi'a ideals.

Nonetheless, whatever promise al-Sadr's moderate path held was never to be realised; Musa al-Sadr disappeared, and was assumed assassinated, during a visit to Libya in 1978. Al-Sadr's disappearance remains unsolved to this day, although then Libyan leader Muammar Gaddafi is suspected of having ordered his killing187. Despite al-Sadr's untimely disappearance, it would not only be his initial politicisation of local Shi'a that would ultimately make them so receptive to ideals espoused by the Iranian Revolution, it would also be because of the very networks established between al-Sadr and Iran before that country's revolution that the revolution would consequently be imported so efficiently into Southern Lebanon ${ }^{188}$. As such al-Sadr influenced the ultimate formation of Hizbullah ${ }^{189}$.

\footnotetext{
${ }^{184}$ Shanahan, The Shi'a of Lebanon: Clans, Parties and Clerics, p. 106.

185 Hamzeh, op. cit., p. 21.

186 Byman, D. (2005). Deadly Connections: States that Sponsor Terrorism. New York:

Cambridge University Press, p. 82.

187 Norton, Hezbollah: A Short History, p, 21.

188 Ibid, p. 19.

189 Hamzeh, op. cit., p. 14.
} 
Following the disappearance of al-Sadr Amal splintered into factions ${ }^{190}$. Younger members of the movement turned towards Ayatollah Sayyid Muhammad Hussayn Fadlallah, who had been al-Sadr's political as well as ideological rival, and who was more loyal to the idea of a transnational Shi'a identity as opposed to al-Sadr's adherence to one that was more nationalistic ${ }^{191}$.

The Amal Movement quickly found legitimacy and inspiration due to three particular events that all occurred within 12 months of each other ${ }^{192}$ : 1) The aforementioned disappearance of Imam Musa al-Sadr, which resonated with Shi'a Muslim's idea of the occultation of the hidden Imam ${ }^{193}$; 2) Israel's 1978 invasion of predominantly Shi'a southern Lebanon, which to Shi'a was a definitive indication of the state's failure; and 3) The 1979 Shi'a Muslim revolution in Iran, which, not surprisingly, roused other Shi'a throughout the region and triggered a sense of empowerment that allowed them to realise their own political potentiality.

Unlike Hizbullah, who were yet to arrive at the political scene and would seek the backing of Iran because of ideological similarities, the Amal Movement, which was more secular, sought the patronage of Syria. This reflected the movement's more pragmatic secular approach to politics in that it acknowledged the reality of the large Syrian presence already in the country as part of the Arab Deterrent Force (ADF) established by The Arab League in 1976194. But Amal's secularism was beginning to collide with influences emanating from Iran. Hussayn Musawi, the movement's deputy head, was suspicious of the movement's secular nature and accused the group's leaders of having collaborated with Israel. Musawi felt that Amal should be identifying itself primordially as Shi'a and as such should be

\footnotetext{
190 Hamzeh, op. cit., p. 22.

191 Ibid, p. 23.

192 Sirriyeh, op. cit., Paragraph 8; Shanahan, The Shi'a of Lebanon: Clans, Parties and Clerics, p. 107.

193 Hamzeh, op. cit., p. 22.

194 Shanahan, The Shi'a of Lebanon: Clans, Parties and Clerics, p. 112.
} 
replicating the Iranian Revolution within Lebanon ${ }^{195}$. It was this lack of allegiance to Iran, in particularly the lack of primacy then placed on the Ayatollah Khomeini's wilayat al-faqih ${ }^{196}$ (his decrees which pushed for continued Islamic revolution) that caused internal tensions within the Amal Movement, and the eventual departure of Musawi in 1982. Musawi then founded the openly pro-Iranian Islamic Amal in the township of Baalbeck located in the Bekaa region ${ }^{197}$. This 'off shoot' of Amal would eventually spawn Hizbullah.

\section{The Formation of Hizbullah}

Although Hizbullah did not emerge until the early 1980's, the reasons for its ultimate existence can be found as early as the 1970's. Increasing Palestinian activity against Israel in Southern Lebanon, as well as the increasing numbers of Shi'a on the whole, ultimately forced many Shi'a to migrate to Beirut ${ }^{198}$. This, and the further economic deprivation it gave rise to, inexorably brought many Shi'a to the conclusion that the National Pact of 1943 and the Lebanese state in general had failed them ${ }^{199}$. Israel's occupation of Southern Lebanon in 1978, and then its full scale invasion as far north as Beirut in 1982, ultimately convinced many Shi'a that not only had the state system failed them, but that the Amal Movement, whom many Shi'a considered part of that system, had as well ${ }^{200}$. In order to advance their cause many Shi'a therefore believed that they would have to form a more effective militia to match others already in existence. Thus, while Israeli attacks on Southern Lebanon inspired the formation of the Amal Movement, Israel's full-scale invasion and occupation of Southern Lebanon suggested that a higher degree of militancy was required, and that an organisation that could sufficiently counter Israel aggression was a

\footnotetext{
195 Norton, Amal and the Shi'a, p. 88.

196 Sirriyeh, op. cit., Paragraph 8. Wilayat al-faqih, as well as its Persian linguistic counterpart Velayat-e Faqih, literally means 'the rules of the expert/jurisprudence'. In this case they refer to the rules or decrees of the Ayatollah.

197 Shanahan, The Shi'a of Lebanon: Clans, Parties and Clerics, p. 113.

198 Sirriyeh, op. cit., p. 39.

199 Ibid, p. 41.

200 Shanahan, The Shi'a of Lebanon: Clans, Parties and Clerics, p. 111.
} 
necessity ${ }^{201}$. Such an organisation could apparently be found in Hizbullah. Although Sheikh Sayyed Hassan Nasrallah, the Secretary General of Hizbullah, has subsequently stated that it was not in fact the invasion per se, but Israel's brazen attempt to affect politics in another sovereign state, as well as the lack of a viable Lebanese defence to that, that necessitated Hizbullah's creation ${ }^{202}$. Considering this, it is ironic that while the invasion was primarily instigated by Israel to finally rid Lebanon of the PLO, as well as other Palestinian elements that threatened its security, it was ultimately made with little consideration of the effect on the Shi'a community, and consequently spawned a new threat to Israel. Since 1974 the Palestinian National Council (PNC), the legislative body of the PLO, had effectively set up a state-within-a-state in South Lebanon. The Lebanese Shi'a community had effectively become a minority again under this predominantly Sunni and Christian quasi-state, and continued to suffer under this apparent Palestinian occupation ${ }^{203}$. Had Israel truly realised these effects, as well as Shi'a's relatively recent politicisation, and quickly withdrawn once their objectives had been met, it might be fair to say that they would not have subsequently had to deal with the emergence of a militia whose apparent founding raison d'être was Israel's ultimate annihilation. In fact, a relatively quick and decisive military manoeuvre could have courted Shi'a favour, considering their treatment by the occupying Palestinians. But this was not to be; Israel was to remain in south Lebanon for the next twenty years. This continual occupation presented Shi'a with a "crisis catalyst" that greatly bolstered the development of Hizbullah in that it legitimated it and provided it with a "rationale"204.

\footnotetext{
201 Norton, Hezbollah: A Short History, p, 33.

202 National Broadcasting Network. (2003). Hizbullah 1982 - 2002. The Lebanese Parties, Ep. 7 . (Unknown, Trans.) Beirut, Lebanon.

203 Cobban, H. (1985). The Palestinian Liberation Organisation: People, Power and Politics. New York: Cambridge University Press, p. 60.

204 Hamzeh, op. cit., p. 17.
} 
The exact process of Hizbullah's formation is still largely shrouded in secrecy 205 , but it appears that it emerged as the result of serendipitous union of the aforementioned socioeconomic factors that beset the Shi'a community in Lebanon, and numerous theological developments with the Shi'a community itself; namely the political influence of the likes of the recently martyred al-Sadr in Libya, the natural influence and inspiration to be gleamed from the Iranian Shi'a Revolution in 1978, as well as the more militant posturing presented by Musawi's Islamic Amal. In Hizbullah's initial stages it was less a singular organisation, but more a loose conglomerate of the more radical elements of politicised Shi'a ${ }^{206}$. Membership to such groups was often more a "political state of mind" than a declaration of affiliation, often the only commonality was an appreciation of the revolution in Iran, thus allegiances to either Hizbullah or Amal were often shifting, if not simultaneous ${ }^{207}$. Daniel Sobelman states that it is perhaps more accurate to view 1982 as the year that saw the beginning of a process towards Hizbullah's realisation, than the year of its formation proper ${ }^{208}$. Regardless of its actual inauguration, it was not until the February 1985 publication of the 'Open Letter addressed to the Downtrodden', or Mustafadin, that the group publically declared itself ${ }^{209}$. This document, which will be examined in more detail later, basically set out Hizbullah's views on a number of domestic and international issues. It rejected Zionism outright and viewed Israel as an occupying force of Muslim land: as such it was to be destroyed. In addition, the letter also opposed any forms of colonialism and condemned the United States of America as an imperialistic nation that supported Israel. The document also rejected the current confessional political arrangement in Lebanon as oppressive and the cause of Lebanon's current strife. However, Hizbullah tellingly did not enunciate

\footnotetext{
205 Sirriyeh, op. cit., p. 41.

206 Shanahan, The Shi'a of Lebanon: Clans, Parties and Clerics, p. 113.

207 Norton, Amal and the Shi'a, p. 101.

208 Sobelman, D. (2010). Hizbollah - From Terror to Resistance. In C. Jones, \& S. Catignani (Eds.), Israel and Hizbollah: An Assymetric Conflict in Historical and Comparative Perspective. New York: Routledge, p. 51.

${ }^{209}$ Also referred to as the 'Open Letter addressed to the Oppressed' or just the 'Open Letter'; Qassem, op. cit., p. 98; a good translation of the document (which will be covered in more detail later in the thesis) can be found in Alagha, Hizbullah's Documents: From the 1985 Open Letter to the 2009 Manifesto, p. 39.
} 
any political alternative within the document other than to advocate for an Islamic form of governance ${ }^{210}$. After this formal establishment, Hizbullah quickly began recruiting, and establishing schools, media centres, and other social services, in Southern Lebanon, the southern suburbs of Beirut and the Bekaa Valley, the main Shi'a areas of Lebanon ${ }^{211}$. Hizbullah's recruitment was further bolstered by the return of many Shi'a who had been fighting for other non-Shi'a militias, but who now found a sectarian organisation that represented their confession 212 .

The circumstances and environ that Hizbullah found themselves in upon their emergence was, not surprisingly, conducive to their favoured mode of militancy. This was greatly bolstered by the absence of an effective central government that normally would have sought to curtail such activities ${ }^{213}$. This certainly appealed to Hizbullah's initial goal of ultimately establishing an Islamic state, ostensibly mirroring that in Iran ${ }^{214}$. Whereas Amal had provided Shi'a with a pragmatic path towards political representation and betterment, Hizbullah suddenly presented Shi'a with a more militant approach, and a viable alternative from their traditional political acquiescence ${ }^{215}$. And it was this militancy that best defines Hizbullah's modus operandi from its inception until 1990. By essentially adopting a jihadist ${ }^{216}$ approach, that is, conceiving of their action as a religious duty, the first step in achieving an Islamic revolution within Lebanon was clearly to rid it of any foreign imperialist presence; namely, Israel, the United States of America, and France ${ }^{217}$. America was targeted as it was essentially seen as

\footnotetext{
210 Shanahan, The Shi'a of Lebanon: Clans, Parties and Clerics, p. 115.

211 Sirriyeh, op. cit., p. 42.

212 Shanahan, The Shi'a of Lebanon: Clans, Parties and Clerics, p. 117.

213 Sobelman, op. cit., p. 53.

${ }^{214}$ Hamzeh, op. cit., p. 80.

215 Shanahan, The Shi'a of Lebanon: Clans, Parties and Clerics, p. 113.

216 'Jihad' is a much-misunderstood term, particularly in the West where it has connotations of fanaticism and dogmatic belief. In Arabic its most basic meaning is 'struggle'. Thus a jihadist (Arabic 'mujahadin') is 'one who struggles'. In Islam jihad can then take on one or two meanings: 1) 'greater jihad' which is the internal struggle to pursue a life in accordance with Islam; and 2) 'lesser jihad', which is the exterior struggle against those who oppose Islam. This latter meaning does not necessarily imply fanaticism or terrorism, which is how the term is often used in Western media. See Hamzeh, op. cit., p. 36.

217 Hamzeh, op. cit., p. 81; Norton, Hezbollah: A Short History, p, 38.
} 
the patron of Israel and a supporter of Zionism. Israel clearly was targeted because it was seen as an expansionist Zionist power. France, on the other hand, was targeted for its continual support of Maronite militias ${ }^{218}$.

The complicated years of the Lebanese civil war are defined by continually shifting alliances, complex sectarian and familial interconnections, competing militias often with mutual objectives, as well as by the local agendas of particular families not necessarily aligned with any militia. Because of these factors it is often hard, if not impossible, to always accurately apportion agency to certain militia actors in regards to numerous other attacks and activities that took place. We do well to bear this in mind when we look at many of the terrorist attacks, hijackings and kidnappings that took place during the chaotic years of the civil war. In fact much of the terrorist activity in the 1980s and 1990s both bears the hallmarks of, and can be traced to, Iranian instigation rather than Hizbullah ${ }^{219}$. Yet considering this it would still be fair to say that Hizbullah initially adopted predominantly terroristic methods ideologically centred on martyrdom in the early 1980's. The organisation launched what is generally considered its first operation in Tyre, Southern Lebanon in 1982, when a young jihadist blew up the Israeli Defence Force's (IDF) military headquarters, killing himself and ninety Israeli soldiers ${ }^{220}$. Similar operations were also carried out, if not under Hizbullah directly, then at least with their tacit approval against the American Embassy in Beirut in April of 1983, killing eighty personal and civilian visitors. Further attacks were made in October of that same year at the American marine compound at Beirut international airport, killing 241 persons, and on the same day, at the French air force barracks in Beirut, killing 80 French soldiers ${ }^{221}$. Whether the direct action of Hizbullah or not, as far as the organisation was concerned, these two attacks quickly achieved one of the organisation's main objectives; both French and American troops ultimately pulled out of Lebanon by the beginning of 1984 .

\footnotetext{
218 Norton, Hezbollah: A Short History, p, 37.

219 Ibid, p. 77.

${ }^{220}$ Hamzeh, op. cit., p. 81.

221 Ibid, p. 83.
} 
Such is the case also with the spate of hostage takings that occurred in the mid-1980's, in which French, American and British citizens were taken, as well as the hijacking of planes, particularly that of a TWA plane in 1985. Various commentators generally attribute many of these to Hizbullah, or at least to other groups aligned with Hizbullah ${ }^{222}$, although Hizbullah for its part has generally denied any culpability for such acts 223 .

Regardless of Hizbullah's involvement in such terroristic activities, it was their mid-1980's concentration on guerrilla warfare, that solidified the organisation's formidable reputation among both Shi'a and the non-Shi'a militia alike. Hizbullah's infantry consisted of those drawn from the poorer areas of South Lebanon and the Bekaa Valley. Therefore they tended to be mainly civilians who were driven by ideological fervour ${ }^{224}$. Propelled as they were by the jihadist struggle to bring an Islamic revolution to Lebanon Hizbullah's soldiers presented themselves as formidable foes, were perceived as being much more disciplined, and not susceptible to banditry as many in other militias were ${ }^{225}$. This combined with their propensity towards martyrdom, that is being prepared to sacrifice their lives for the struggle, presented their adversaries with a much more troubling form of combat.

It was the formidable success of Hizbullah in achieving its objectives by guerrilla warfare that placed them in direct competition with Amal226. Both were now contending to represent the Shi'a identity within Lebanon. Amal's secularism translated into a desire to work within the existent political system, whereas Hizbullah viewed this system as corrupt and needing to be replaced $^{227}$. This competition came to a head in 1988 during the endgame of the civil war, when both directly fought for dominance in the Shi'a strongholds of Southern Lebanon and the southern suburbs of Beirut. This

\footnotetext{
222 Hamzeh, op. cit., p. 85; Norton, Hezbollah: A Short History, p, 42.

223 Avon, D., \& Khatchadourian, A. T., op. cit., p. 27; Hamzeh, op. cit., p. 86.

224 Ibid, p. 72.

225 Ibid, p. 87.

226 Norton, Hezbollah: A Short History, p, 43.

227 Ibid, p. 45.
} 
fighting only came to an end with a peace deal brokered by both Syria and Iran $^{228}$. Yet, both groups would soon need to present viable and coherent political futures for Shi'a with the end of the Lebanese civil war in 1990.

\section{Hizbullah's Dual Roles}

As outlined previously, the fifteen-year civil war came to an end in 1990 with the implementation of the Taif Accord, which had been signed the previous year by most militias and political parties. Hizbullah was largely opposed to the implementation of the Taif Accord, but because it had no political representation it had no substantive way of influencing any outcome. It therefore tried to form a political bloc to fight it but the enactment of the accord appeared inevitable. Fifteen years of civil war lent a sense of urgency to finding a resolution and as a result most other political groups $^{229}$ (invariably representing their respective militias) were in support of the conditions laid out in the agreement, even if it did not accord exactly with their own ideal goals. As such the Taif Accord represents a compromise between parties rather than an agreement proper 230 . Hizbullah's main concern with the accord was that it appeared to be concerned with consolidating a system that had already failed once. Moreover, it was silent on the matter of Israel's occupation. Nasrallah considered all other concerns as specious and secondary, and that the unity of Lebanon should be achieved from a common enmity to Israel. He stated in 1992 soon after becoming the secretary general of Hizbullah:

"There is a priority issue that the Lebanese have to agree on, namely whether the Israeli is an enemy or not. They went to Taif... and discussed several issues at length. While the serious and important issue that they should discuss is their position regarding Israel, and in particular whether or not Israel is the enemy of Lebanon and its people."231

\footnotetext{
228 Shanahan, The Shi'a of Lebanon: Clans, Parties and Clerics, p. 117.

229 Rabil, R. G. (2012). Hezbollah, The Islamic Association and Lebanon's Confessional System. The Levantine Review , 1 (1), p. 52.

230 Krayem, op. cit., p. 482

231 Noe, op. cit., p. 63.
} 
Nasrallah continues that this should be central as there were no other "intellectual, ideological or religious denominators" 232 that united the country. That Hizbullah finally did go along with the passing of the accord was because of three main factors: 1) The accord was sponsored by Syria, the only other power, internal or external, it could see that shared its hatred towards Israel; 2) that both Syria and the Lebanese state would not obstruct Hizbullah in its continual resistance to Israel ${ }^{233}$; and 3) the accord was to bring an end to the civil war 234 .

The reestablishment of a viable central government meant that all parties, Hizbullah included, would now need to be encouraged to devote themselves to their political aspirations, as opposed to the imposition of might to achieve their goals. Within this reformed consociational government Shi'a now found themselves with two main avenues of possible representation within politics; Amal and Hizbullah ${ }^{235}$. Amal's secularist approach meant that it required minimal adjustments to participate and to represent Shi'a. Amal's participation also meant that Hizbullah would need to focus on politics if it was to remain relevant to the Shi'a of Lebanon. Yet to participate within the existent political system required a radical shift in position for Hizbullah, as this would contradict its original stated intention of Islamic revolution, leave alone its continuing assertion that it wanted no part of a confessional system that it claimed was corrupt. Hizbullah found a way around this conundrum by formulating two distinct functions: that as a political actor, and that as a resistance movement ${ }^{236}$. This way, it could continue to sufficiently function under the Taif Accord. Moreover, when it did enter the political arena it decided it would stay out of out of the cabinet and operate only as an oppositional force within parliament 237 . In practice, Hizbullah has stated that it does not support the system explicitly, but that it sees this as the only viable way to achieve the modifications of that system

\footnotetext{
232 Ibid, p. 64.

233 Rabil, op. cit., p. 52.

234 Shanahan, The Shi'a of Lebanon: Clans, Parties and Clerics, p. 124.

235 Ibid, p. 118.

236 Rabil, op. cit., p. 52.

237 Shanahan, The Shi'a of Lebanon: Clans, Parties and Clerics, p. 123.
} 
that it desires 238 , nor does participation in a system necessarily indicate a commitment to preserve that system as it is ${ }^{239}$. Rationalising the conflict of ideological principles and objective reality by using Muslim jurisprudence, Haytham Mouzahem, a Hizbullah party official, stated that: "Necessity permits what is otherwise prohibited... When two duties are competing, focus on the most important one." 240

One of the requirements of signatories to the Taif Accord was for all militias to disarm. This was mostly achieved, with the exception of Hizbullah who refused to abide by this condition. Hizbullah cited its need to maintain its resistance to Israel's continuing occupation of Southern Lebanon, which was also being accomplished through the assistance of the South Lebanese Army $(\mathrm{SLA})^{241}$, a militia that had originally splintered from the Lebanese Army proper during the early days of the civil war. To legitimise this Hizbullah repositioned itself as a resistance movement, still with a legitimate goal, as opposed to a militia. This realignment by Hizbullah had wide, albeit not unanimous, support throughout Lebanon, not surprisingly from Shi'a in particular ${ }^{242}$. Any acceptance of this by the Lebanese in general was because they now saw Hizbullah's militia potential as being effectively neutralised. This was because the organisation's aggressive potentiality, manifested through its refusal to disarm, was now apparently to be solely focussed on resistance to the Israeli occupation ${ }^{243}$.

By the early 1990s, Hizbullah therefore found that they now had two dual roles and were operating within two arenas within Lebanon: a military theatre in Southern Lebanon and the political arena of Beirut. Despite its entry into the more 'civilised' realm of politics, Hizbullah's military engagements with Israel did not show any sign of abatement. That being

\footnotetext{
238 Ibid, p. 124.

${ }^{239}$ Rabil, op. cit., p. 53.

240 Interview with Haytham Mouzahem, Shu'n al-Awsat 59, Jan-Feb 1997; cited by Shanahan, The Shi'a of Lebanon: Clans, Parties and Clerics, p. 124, p. 190n.

241 Sobelman, op. cit., p. 53.

242 Harik, op. cit., p. 48; Norton, Hezbollah: A Short History, p. 83.

243 Shanahan, The Shi'a of Lebanon: Clans, Parties and Clerics, p. 118.
} 
said, Hizbullah and Israel's confrontations during the 1990's were surprisingly measured. Both sides essentially adhered to the 'rules of the game' that were first established in an oral agreement in 1993, whereby both parties agreed to not target civilians, and where Hizbullah promised to confine its military campaign to the 'security zone' in Southern Lebanon retained by Israel 244 .

Adherence to these so-called 'rules of the game' was not strict; two particular military campaigns, that in retrospect were counterproductive to Israel, bore this out. The first Israeli attack was Operation 'Accountability' in July of 1993. This offensive saw Israel push into Lebanon following the loss of seven Israeli soldiers in clashes with Hizbullah. Israel hoped to drive Shi'a North into Beirut in the hope of turning the Lebanese population in general against Hizbullah. Hizbullah managed to successfully counter this offensive by launching a barrage of Katyusha rockets into northern Israel. This clash only came to an end with an 'understanding' between Israel, Syria and Lebanon, brokered by the United States of America ${ }^{245}$. The second Israeli campaign was Operation 'Grapes of Wrath in April of 1996. This operation had a far more detrimental effect for Israel, and bolstered Hizbullah's position in the eyes of the Lebanese ${ }^{246}$. In this event, following the killing of Israeli civilians by Hizbullah rockets, Israel launched air attacks on both southern Lebanon and, for the first time since 1982, on the southern suburbs of Beirut. Israel again hoped that it could steer the support of the general Lebanese population against the organisation. Any hopes of this being achieved were dashed with the shelling of a United Nations compound in the village of Qana in southern Lebanon on the $18^{\text {th }}$ of April 1996. Civilians had flocked to the compound in search of safety, 106 were killed and 116 injured $^{247}$.

\footnotetext{
${ }^{244}$ Norton, Hezbollah: A Short History, p. 43; Sobelman, op. cit., p. 54

245 Ibid, p. 55.

246 Ibid, p. 57.

247 Norton, Hezbollah: A Short History, p. 84.
} 
On both these occasions Hizbullah effectively managed to achieve a strategic balance against Israel, and by doing so to also retain support of local Shi'a despite the continual provocation of Israel, and the effects of its retaliation. This equivalence is surprising considering that both Israel and the South Lebanese Army combined had the potential to overwhelm and definitively stop all of Hizbullah's operations should they have so chosen ${ }^{248}$. That they didn't perhaps shows a concern with international public relations and Israel's fear of retribution from Hizbullah, which had demonstrably shown in the past Israel's inability to stop even relatively primitive Katyusha rockets descending on its northern settlements. Moreover, considering the inequality in resources and training, it is surprising that from 1982 until 1999 the rates of those either killed or wounded between Hizbullah and both Israel and the SLA combined was near parity ${ }^{249}$. Hizbullah had surprisingly managed to bolster both its military and political standing within Lebanon, turning Israel aggression to its favour. This was to occur again with Israel's decision to unilaterally withdraw in 2000.

\section{Hizbullah's Wavering Public Support}

Israel's continual occupation of southern Lebanon was, not surprisingly, proving expensive and not bearing any tangible benefits; the so-called 'security zone' had failed to stymie Hizbullah attacks ${ }^{250}$. The occupation therefore became a central issue in the 1999 Israeli election campaign. Ehud Barak won the election as in his campaign he had promised to withdraw Israeli troops from Southern Lebanon within 12 months of his becoming prime minister as part of a more concerted effort to reach peace deals within the region ${ }^{251}$. Israel finally withdrew from Lebanon in May of 2000. This withdrawal was a unilateral move by Israel following the breakdown of

\footnotetext{
248 Hamzeh, op. cit., p. 85; Norton, Hezbollah: A Short History, p, 93.

${ }^{249}$ From 1982 until 1999 Hizbullah suffered 1248 fatalities, with 1000 wounded. The SLA had 1050 fatalities and 639 wounded. Israel, 200 fatalities and 300 wounded. See Hamzeh, op. cit., p. 85; Norton, Hezbollah: A Short History, p. 94.

250 Steinberg, G. M. (2007). Foreign Policy in the 1999 Israeli Elections. Israel Affairs , 7 (23), p. 191.

251 Norton, Hezbollah: A Short History, p. 88.
} 
peace talks with Syria. Despite this, Hizbullah viewed the withdrawal as the result of their continual resistance and, therefore, an unequivocal triumph on their part ${ }^{252}$. And they could claim a modicum of victory; for the first time in history Israel had unconditionally pulled out from an Arab land without a peace treaty or any other form of agreement ${ }^{253}$. The displaced Shi'a community also invariably also saw it as such as they returned in thousands to their original homes and villages in Southern Lebanon ${ }^{254}$.

Despite this 'success', Israel's withdrawal from Lebanon presented a conundrum for Hizbullah, who now found the main reason for their continuing armament contra the Taif Accord no longer justifiable ${ }^{255}$. Internal tensions arose about whether to reconfigure and concentrate more on their political projects, or to maintain their resistance towards Israel in some other form. Hizbullah's final decision was to continue with the resistance albeit through two different avenues. Because Israel still occupied the Shebaa Farms area of the Golan Heights, Hizbullah viewed their withdrawal as incomplete and this thereby justified continued armed resistance ${ }^{256}$. Although this reasoning by Hizbullah is not necessarily sound: the claim in itself is still in dispute. The United Nations currently consider Shebaa Farms to be part of the larger Golan Heights, and therefore to be Syrian land. Because of this, Israel was under no obligation to withdraw from Shebaa Farms as per the UN Security Council Resolution $425^{257}$. Reference to archives by all parties involved (that is, Lebanon, Syria and Israel) revealed that no clear demarcation had ever been undertaken and the issue remained unresolved. However, the issue was simplified somewhat when Syria conceded that Shebaa Farms were in fact part of

\footnotetext{
252 Sobelman, op. cit., p. 61.

253 Zisser, E. (2002). The Return of Hizbullah. Middle East Quarterly, 9 (4), p. 4.

254 Norton, Hezbollah: A Short History, p. 90.

255 Sobelman, op. cit., p. 61.

256 Norton, Hezbollah: A Short History, p. 91.

257 Sobelman, op. cit., p. 60.
} 
Southern Lebanon ${ }^{258}$. Israel construes this move by Syria to be an attempt to find a pretext to continue the resistance against it by Hizbullah ${ }^{259}$.

In addition to fighting for the Shebaa Farms, Hizbullah would from now on also provide direct support to the Palestinians in their ongoing confrontation with Israel ${ }^{260}$, although Sayyed Hassan Nasrallah has also stated that in the end it must be Palestinians themselves who ultimately liberate Palestine 261 . Up to now Hizbullah had been careful to downplay its support of Palestinian insurgency groups, but the organisation now blatantly supported both Hamas and the second intifada that began in September of 2000. Going so far as to dedicate much of its programming on al-Mana, its main television network, to furthering the cause ${ }^{262}$. These alterations in focus were met by disquiet from Lebanese politicians and civil society. The existence of this force contra that of the state began to be met with unease, and questions were being asked about Hizbullah's loyalty towards national interests. Support for Hizbullah began to decrease ${ }^{263}$.

Popular support for the organisation was to further decrease, when Rafiq alHariri, the then prime minister, was assassinated in a car-bomb explosion in downtown Beirut in February of 2005. Hariri, a Sunni Muslim as per requirements of the National Pact, had largely been seen as the architect of Lebanon's post-war reconstruction ${ }^{264}$. But he was also largely responsible for consolidating a formidable opposition with Druze and Maronites against the then current pro-Syrian government ${ }^{265}$. This alliance, which had already

\footnotetext{
258 Kaufman, A. (2004). Understanding The Shebaa Farms Dispute: Roots of the Anomaly and Prospects of Resolution. Palestine-Israel Journal of Politics, Economics, and Culture , 11 (1), p. 38.

259 Kaufman, A. (2002). Who Owns the Shebaa Farms? Chronicle of a Territorial Dispute. The Middle East Journal , 56 (4), p. 594.

260 Noe, Voice of Hezbollah: The Statements of Sayyed Hassan Nasrallah, p. 244.

${ }^{261}$ Norton, Hezbollah: A Short History, p. 93.

262 Zisser, op. cit., p. 6.

263 Sobelman, op. cit., p. 62.

264 Hariri was more than the architect figuratively; Hariri founded the Lebanese company Solidere in 1994. This company controversially won the tender for the reconstruction of post-war downtown Beirut as well as other major reconstruction projects in Lebanon. The central business district of Beirut therefore now has the unofficial name of Solidere. 265 Knio, K. (2005). Lebanon: Cedar Revolution or Neo-Sectarian Partition? Mediterranean Politics , 10 (2), p. 225.
} 
been calling for Syria's withdrawal from Lebanon, now blamed the country for Hariri's death 266. Popular large-scale demonstrations by Druze, Christians and Sunni Muslims, the so-called 'Cedar Revolution', echoed this call for Syria to leave Lebanon. Syria subsequently withdrew from Lebanon the following April. Considering the near total political control that Syria had exercised of Lebanon for the last 15 years, this withdrawal was "swift, unplanned and humiliating"267. Hizbullah had now lost its main patron and by association was implicated in the assassination. Because of this, serious political debate now turned to the role of Hizbullah, and its future within Lebanon $^{268}$. Sensing a new political reality within Lebanon, and a sharp decline in support, Hizbullah finally decided to allow its members to fully participate in national politics. Later in the year, following a series of elections that were the first devoid of Syrian influence, Hizbullah won 14 out of the 128 seats in the National Assembly ${ }^{269}$. Further to this, two of its members entered the cabinet for the first time in July $2005^{270}$.

In spite of this turn to politics, Hizbullah's resistance in the South did not relent. Yet, despite Hizbullah's insistence on essentially continuing the resistance as before, from the time of Israel's withdrawal until 2006, save for occasional minor cross border clashes and continual rhetoric from both sides, the period was relatively quiet ${ }^{271}$. Where skirmishes did occur they were invariably confined to the Shebaa Farms area and then still signalled a return to the so-called 'rules of the game'272. Hizbullah has described its engagements with Israel during this period of comparative calm as mostly consisting of 'reminder' operations ${ }^{273}$. The general feeling among the Lebanese by this time was that while Hizbullah was providing and maintaining an effective deterrent against Israeli aggression in the South, it

\footnotetext{
${ }^{266}$ Ajami, F. (2005). The Autumn of the Autocrats. Foreign Affairs , 84 (3), pp. 20-35.

267 Knio, op. cit., p. 225.

268 Ibid, p. 226.

269 International Foundation for Electoral Systems. (2009, June 9). Lebanon's 7 June Elections: The Results. Retrieved February 15, 2013 from International Foundation for Electoral Systems: http://www.ifes.org/files/IFES_LebanonReview060709Results.pdf 270 Sobelman, op. cit., p. 63.

271 Norton, Hezbollah: A Short History, p. 91.

272 Ibid, p. 92.

273 Sobelman, op. cit., p. 63.
} 
was time for the Lebanese Army to take on this task ${ }^{274}$. Political talk began to turn to subsuming Hizbullah's arms into a national defence strategy, if not the Lebanese Army proper 275 .

This contention was to be reinforced further following what has become known as the Second Lebanese War in 2006. In that year, in response to Israeli attacks on Hamas within Israel, Hizbullah conducted a cross border incursion that resulted in the death of eight Israeli soldiers and the taking of two soldiers as hostages. Israel responded by launching a ground offensive into Southern Lebanon as well as air raids ${ }^{276}$. In addition to this Israeli bombardments also significantly damaged the southern, predominantly Shi'a, suburbs of Beirut. Israel's disproportionate attack resulted in huge damage to Lebanon's infrastructure. Israel's usual attempt to turn public opinion against Hizbullah appeared to be effective on this occasion. The conflict only came to a cessation with the passing of the United Nations Security Council Resolution 1701, which was unanimously adopted by both sides $^{277}$. Along with the usual proclamations directed at Israel regarding the importance of respecting Lebanese sovereignty, this resolution also demanded that it was the Lebanese Government alone who should have full control of that sovereignty. The Resolution also stipulated that all militias should be disarmed (that is, Hizbullah) and that only UNIFIL and the Lebanese Armed Forces (LAF) should be deployed in South Lebanon. For the first time in 20 years, the LAF now found itself defending the country's southern border against Israel ${ }^{278}$. Hizbullah had now lost its important and significant autonomy in the South. Hizbullah had always used this exclusivity to legitimise its resistance identity, in so far as it perceived the LAF to be too inferior to the Israeli Army and therefore unable to sufficiently

\footnotetext{
274 Norton, Hezbollah: A Short History, p. 93.

275 Ibid, p. 65.

${ }^{276}$ Avon, D., \& Khatchadourian, A. T., op. cit., p. 82.

277 The United Nations Security Council. (2006, August 11). Resolution 1701. Retrieved February 10, 2013 from The United Naitons : http://www.un.org/News/Press/docs/2006/sc8808.doc.htm 278 Sobelman, op. cit., p. 65.
} 
perform this role ${ }^{279}$. As the organisation was now out of favour and significantly isolated within the state ${ }^{280}$, debates in parliament began on formulating a 'roadmap' with a view to Hizbullah's eventual disarmament.

The apparent necessity for this to happen was further indicated in May of 2008. By this time the Lebanese parliament had been in stalemate for sixteen months, and without a President for six ${ }^{281}$. In an effort to assert some authority in this vacuum, the government, for the first time, made an explicit effort to curtail Hizbullah's military strength. Walid Jumblatt, the high-profile influential leader of the secular Progressive Socialist Party, and an avowed enemy of Hizbullah, accused the organisation of having established a surveillance system at the international airport in Beirut ${ }^{282}$. As a result the Lebanese government attempted to suspend the security chief of the airport, a general from the Lebanese Armed Forces, who was apparently aligned with Hizbullah. Jumblatt had also accused the security chief of having shared information regarding the movement of state officials. Information that he claimed had been obtained from Hizbullah's alleged surveillance system ${ }^{283}$. Further to this attempts were also made to dismantle Hizbullah's unlicensed telephone network ${ }^{284}$. The organisation had installed its own fibre optic network connecting its offices in Beirut and South Lebanon, and was now apparently expanding it into the Bekaa Valley ${ }^{285}$. Hizbullah perceived this latter effort as an attempt to compromise its military capabilities and went on the offensive, for the first time turning its military might against its Lebanese compatriots. Sectarian violence quickly broke out and pitched street battles were fought throughout Beirut, and other regional centres. The Lebanese Army, which conscripts from all confessions, was wary of intervening. This was because it feared that

\footnotetext{
279 Qassem, op. cit., p. 34.

280 Sobelman, op. cit., p. 64.

281 Baliani, D. (2008). Lebanon: The Doha Agreement Ends the first Restructuring Phase in the Post-Syrian Lebanon. CeMiss Quarterly, 6 (2), p. 5.

282 Blanford, N. (2008, May 7). A Cell Phone War in Lebanon. Retrieved February 7, 2013

from Time World: http://www.time.com/time/world/article/0,8599,1738255,00.html

${ }^{283}$ Baliani, op. cit., p. 5.

${ }^{284}$ Avon, D., \& Khatchadourian, A. T. op. cit., p. 91.

285 Blanford, op. cit.
} 
clashes with Hizbullah, and the other Shi'a groups aligned with it, would cause internal tensions within the army and it to splinter along sectarian lines ${ }^{286}$, as was essentially the case in the civil war. Beirut teetered again on the edge of civil war.

Tensions were only eased, and all parties only agreed to lay down their arms, with the eventual belated intervention of the Lebanese Army, as well as the implementation of the Doha Agreement. By this time 81 people had been killed. This accord was instigated by Emir Sheikh Hamad al-Thani of Qatar. Concerned, as many were, that the sectarian violence was going to escalate into another civil war, the Emir invited all the political leaders of Lebanon to Doha, Qatar to mediate an agreement between all of the involved factions. The resulting agreement stipulated that the participating militias were to no longer resort to arms, and that all parties were to refrain from rhetoric that could be construed as treasonous. Further to this, more adjustments were made to the electoral map; a national unity government was to be formed that consisted of 30 ministers, 11 of which were to be in the opposition. As Hizbullah held sway over the opposition, this modification was to the group's advantage as it basically provided them with veto power, as government decisions required a two-thirds majority to pass $^{287}$.

These electoral reforms were fortuitous for Hizbullah, as the organisation was fast losing its unspoken privileged place within Lebanon. The occurrences in 2008 caused a high level of distrust by the general population of Lebanon against Hizbullah, as many Lebanese believed that the organisation still held on to its revolutionary vision of an Islamist state. This was particularly the case after Nasrallah, following the signing of the Doha Agreement, restated that Hizbullah was still loyal to the Wilayat al-

286 Wheeler, C., \& Gilbert, B. (2008, 5 10). Lebanese Army won't take on Hizbollah. Retrieved 1 10, 2013, from The Telegraph:

http://www.telegraph.co.uk/news/worldnews/middleeast/lebanon/1944737/Lebanesearmy-wont-take-on-Hizbollah.html

287 Baliani, op. cit., p. 10; Avon, D., \& Khatchadourian, A. T., op. cit., p. 92. 
Faqih of the Ayatollah in Iran. This reinforced an already prevalent belief that the group were pan-Islamists first, and nationalists second ${ }^{288}$. Misgivings were particularly strong among the majority Sunni against Shi'a in general, and against Hizbullah in particular, which Sunni Muslims perceive to be the only current effective representation of this community ${ }^{289}$. Regardless, Hizbullah continues to be very popular among the Shi'a community.

Any public support that is retained by Hizbullah, from both Shi'a and nonShi'a alike, appears to be primarily based on its purveyance of social services $^{290}$, and not necessarily based on its political and military activities. These social services have catered mostly towards servicing low-income Shi'a families located in the southern suburbs of Beirut, the Bekaa Valley, and South Lebanon (see Figures $4 \& 5$ ). However, since entering politics and possibly to acquire more support, Hizbullah had also reached out to the nonShi'a community as well ${ }^{291}$, although this could also be construed as simply an attempt to garnering popular support for their militia activity ${ }^{292}$. These social services therefore played to both of Hizbullah's dual roles as the 'resistance' to Israel and as the only powerful means of political representation for Shi'a. This last issue has translated into the resumption of harmonious relations between Amal and Hizbullah. Both of which have perceived an increase in animosity toward Shi'a ${ }^{293}$. That this community now felt increasingly under siege may in part be because of the perceived arrogance of Hizbullah in that it had continually 'overplayed its hand' in not exclusively dedicated itself to participating in the Lebanese political system. Further to this, it had also behaved also as a state-within-a-state in its

288 Salamey, I., \& Copeland, G. (2011). How exceptional are Islamists? Comparing Support for Hezbollah and the Lebanese Forces. Journal of Balkan and Near Eastern Studies, 13 (2), p. 161.

${ }^{289}$ Avon, D., \& Khatchadourian, op. cit., p. 97.

290 Ibid, p. 99.

291 Cammett, M., \& Issar, S. (2010). Bricks and Mortar Clientelism: Sectarianism and the Logics of Welfare Allocation in Lebanon. World Politics , 62 (3), p. 416; Flanigan, S. T., \& Abdel-Samad, M. (2009). Hezbollah's Social Jihad: Nonprofits as Resistance Organisations. Middle East Policy, 16 (2), p. 125.

292 Atzili, B. (2010). State Weakness and "Vacuum of Power" in Lebanon. Studies in Conflict \& Terrorism , 33 (8), p. 768.

293 Avon, D., \& Khatchadourian, A.-T., op. cit., p. 98. 
operations as a resistance movement and as a purveyor of services traditionally associated with the state.

From its emergence Hizbullah has played a balancing game of legitimacy. Its resistance towards Israel has essentially required it to continue its militia strategies, albeit under the guise of a sub-state resistance organisation representing Shi'a. This has necessitated its retention of arms, which contravenes the Taif Accord, numerous United Nations resolutions, and the demands of the Lebanese government. Its entry into politics has complicated this position even further. This is because for the organisation to be effective in this arena it requires widespread support from a populace that is wary of its intentions. This is particularly so since the events of 2008 when, for the first time, Hizbullah went on the offensive against the state. These two roles of Hizbullah's do not always accord with each other, and an either/or rather than a both/and proposition may be required. In the following chapter this work will examine these two identities separately; namely Hizbullah's Shi'a identity which largely defined its initial formulation as a revolutionary militia, and its identity as a resistance movement since entering politics. As the organisation has moved into the political sphere its has attempted to retain its Shi'a identity but has attempted to portray itself more as a resistance movement proper. This latter identity has allowed the organisation to appeal to a broader base of the population as the resistance can be construed as a patriotic project. 


\section{Figure 4}

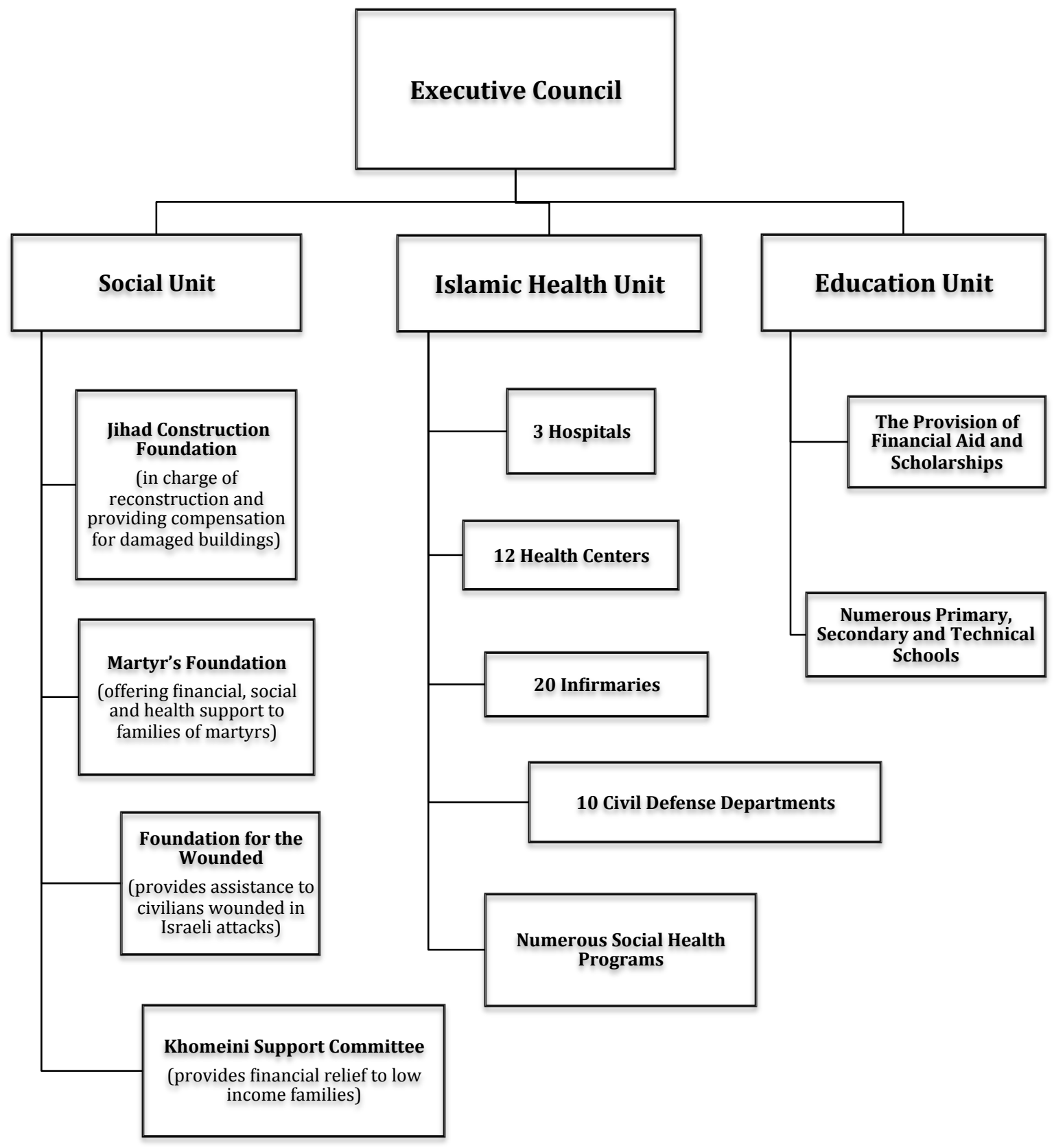

Hizbullah's social services ${ }^{294}$.

${ }^{294}$ Adapted from Flanigan, op. cit., p. 125. 


\section{Figure 5}

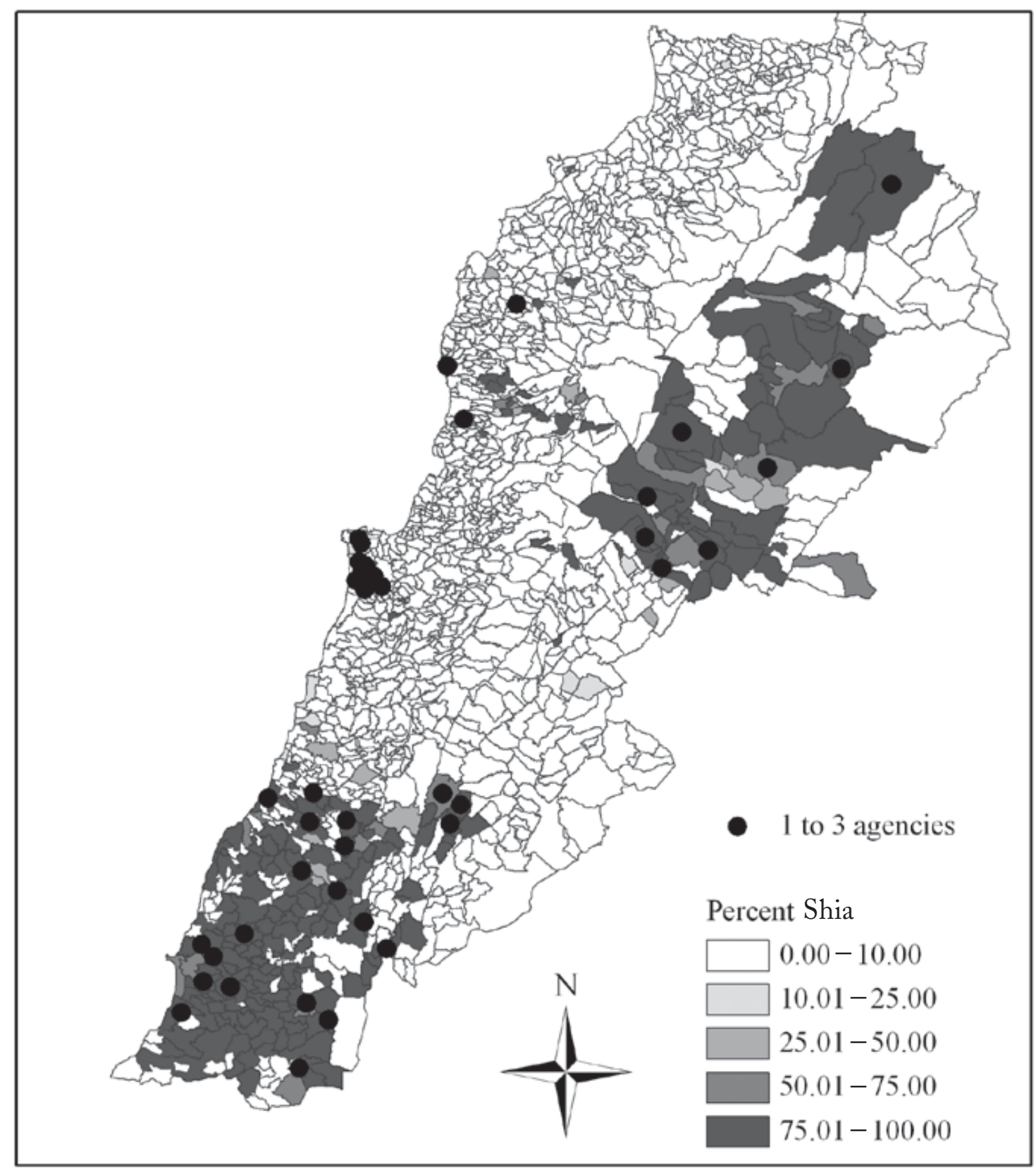

The location of Hizbullah's welfare agencies and the demographic distribution of Shi'a Muslim communities 295 .

295 Adapted from Cammett, M., \& Issar, S., op. cit., p. 405. 


\section{Hizbullah's Identity Transformation}

In this chapter Hizbullah's initial identification with Shi's Islam, and then its movement away from this towards portraying itself more as a resistance movement, will be discussed. This chapter argues that the organisation's initial identity was essentially primordial in nature and because of this, it greatly helped bolster the appeal of the organisation's initial revolutionary ideals. Of the three serendipitous factors that encouraged the emergence of Hizbullah, it is the Islamic Revolution in Iran that had the most direct operational and ideological influence on Hizbullah's initial outlook. This revolution dispensed with a secularist monarchy and was replaced by a Shi'a theocracy. The Islamic Constitution that was implemented in Iran after the revolution largely defines the early principles and organisational structure of Hizbullah. This is particularly reflected in the aforementioned 'Open Letter' from 1985, which will be examined in greater depth. However, even prior to Hizbullah's entry into politics the importance of this revolutionary Shi'a identity was being downplayed, as the group realise the practical realities of Lebanon, leave alone whether they become political or not.

Hizbullah then found that it had to radically alter its identity once it decided to enter into the politic arena of Lebanon. It will be argued that in order for this to be achieved, it demanded a reorientation of the identity that Hizbullah had been projecting locally and regionally. This move was necessitated by not only the new political reality of post-civil war Lebanon, but the reduction of regional patronage, primarily that of Iran. The key consideration for the organisation was the garnering of public support, not only from Shi'a, but also from other communities within Lebanon. Hizbullah adopted an instrumentalist approach towards this identity formulation in order to achieve this. To this end, Hizbullah decided to concentrate on its resistance activities, which, at the time, had popular support amongst the 
Lebanese ${ }^{296}$. Although the organisation had been operating as a resistance movement in regards to the occupation of Southern Lebanon by Israel, and its ally the Southern Lebanon Army, it then found that, with the withdrawal of Israel in 2000, this identity no longer held the currency that it did. Despite this, Hizbullah still retains this approach. An examination of Hizbullah's 2009 document, the 'new manifesto' will demonstrate that, while Hizbullah still retains ideological leanings inherited from it's initial patron, Iran, it is its identity as a resistance organisation that is being retained as it positions itself in the political realities of Lebanon in the new millennium.

The first part of this section looks at the importance of identity in Lebanon, in particularly how primordial identities significantly permeate all strata of Lebanese society. It is important to appreciate this as it suggests that Hizbullah's adoption of the explicitly Shi'a revolutionary ideals from Iran marked its primordial identity as Shi'a, although Hizbullah did not necessarily just represent, and seek to advance, the needs of its Shi'a supporters alone. The next section examines the salient points of the Iranian Revolution, and how this successful uprising was also essentially the reestablishment of Shi'a identity as a response to aggressive modernisation and secularisation within Iran. This is relevant in so far as Iran also sought to export its vision of pan-Shi'ism, particularly in its neighbours, and found a receptive partner in Hizbullah. I will then seek to explain how this translated into the patronage of Hizbullah, and how this is reflected in Hizbullah's founding document, the 'Open Letter' published in 1985.

The second part of this chapter looks at Hizbullah's movement away from placing primacy on its Shi'a identity. The group moved away from its default position as a Shi'a organisation and adopted an identity that was more conducive to political success within Lebanon. Realising the political reality within Lebanon, and the need for a broader support base Hizbullah placed emphasise on that which it had proved successful at, and which, initially at

296 Harik, op. cit., p. 48. 
least, proved popular amongst the non-Shi'a of Lebanon; its resistance against Israel. This newer identity was therefore instrumental in nature. Hizbullah has retained this identity as it moves into the new millennia. It has equated its resistance with that in other countries, including rebellions in its neighbouring states, particularly those from the so-called 'Arab Spring'. Its adherence to this doctrine is indicated in the 'New Manifesto' of 2009. This document will be examined in the last section of this chapter.

\section{The Importance of Primordial Identities in Lebanon}

Primordial approaches consider ethnicity as fixed, singular and "exogenous to human process"297. Primordial identity is therefore usually the initial identification before other sub-identities are defined. Donald Horowitz, a central proponent of the primordial approach, defines 'ethnicity' as:

“... ascriptive differences, whether the indicium of group identity is color, appearance, language, religion, some other indicator of common origin, or some combination thereof" 298 .

Harold Isaacs defines ethnicity as:

“... the ready made set of endowments and identifications that every individual shares with others from the moment of birth by the chance of the family into which he is born of that given time in that given place" 299 .

For Isaacs, ethnic identity consists of contingencies attached to specific circumstances such as birthplace, language, shared history, religion or nationality. Thus Isaacs considers this type of identity as primordial in the sense that these attributes shape reality and define identity from birth before the subject is conscious of them ${ }^{300}$. Clifford Geertz defines ethnicity in the same way, noting that these primordial bonds are "over powering"301

\footnotetext{
297 Chandra, K. (2012). Introduction. In C. Kanchan (Ed.), Constructivist Theories of Ethnic Politics (p. 520). New York: Oxford University Press, p. 18.

298 Horowitz, D. L. (2000). Ethnic Groups in Conflict. London: University of California Press, Ltd, p. 17.

299 Isaacs, H. (1975). Idols of the Tribe: Group Identity and Political Change. New York:

Harper \& Row Publishers, p. 38.

300 Ibid, p. 40.

301 Geertz, C. (1993). The Interpretation of Cultures: Selected Essays. London: Fontana, p. 259.
} 
and often almost "spiritual"302. This is particularly so when one's religion is used as an identifier.

That ethnic identification has persisted and in fact increased through modernisation has caught many social scientists unprepared 303 . Nevertheless, assumptions have prevailed, particularly since the end of World War Two, that modernisation and industrialisation would slowly erode the saliency of ethnic identity and thereby ethnic conflict would slowly fade away ${ }^{304}$. Lipset and Rokken argue that as ethnically diverse nations experience modernisation in the form of industrialisation and the liberalisation of markets, more universalistic manifestations of identity would prevail and effectively render subordinate ethnic identities redundant ${ }^{305}$. However, Susan Ozark responds to this contention in that she argues that modernisation and economic advancement may actually increase ethnic mobilisation, and subsequently increase the possibility of ethnic conflict. This is because these macro-processes favour organisation at a state level, and ethnic competition is increased at the more local level as different ethnic communities vie for influence ${ }^{306}$.

Such ethnic cleavages have continued to prevail in the Middle East generally, and in Lebanon in particular, despite the onslaught of modernisation, the relative liberalisation of its economy, and the greater drive towards globalisation ${ }^{307}$. In regards to Lebanon, liberalist and/or modernist conceptualisations of ethnicity have not come to pass. Much as Ozark predicts, sectarian divisions that were present even prior to the formation of

\footnotetext{
302 Ibid, p. 109.

${ }^{303}$ Horowitz, op. cit., p. 12.

304 Ibid, p. 13.

305 Lipset, S. M., \& Rokkan, S. (Eds.). (1967). Party Systems and Voter Alignments: CrossNational Perspectives. New York: Free Press.

306 Olzak, S. (1983). Contemporary Ethnic Mobilization. Annual Review of Sociology, 9, p. 363.

307 Smith, A. D. (1990). The Suppression of Nationalism. International Journal of Contemporary Sociology, 28 (1), pp. 1-31.
} 
the modern state of Lebanon have persisted and become more entrenched through the state's subsequent modernisation ${ }^{308}$.

In 1968 Samir Khalaf wrote on the persistence of primordial identities, and the prioritising of tribal and religious loyalty in Lebanon, despite the country's sophisticated political evolution ${ }^{309}$. At the time Khalaf spoke optimistically of the primordial ties in Lebanon and described its political system as a "curious but happy phenomenon ${ }^{310 " . ~ W i t h ~ t h e ~ a d v a n t a g e ~ o f ~}$ hindsight, history proved this assertion as premature; within seven years of Khalaf writing this, Lebanon splintered and devolved into civil war. Yet, despite this early positive view of primordialism in Lebanon, Khalaf was not wrong in overstating the importance of Lebanon's 'primordial ties'. They existed, and still do, on many levels: a) Through kinship, that is, the extended family was still the primary social unit within society often countering both the assertion of individuality and the greater community ${ }^{311}$; b) through feudal ties (or what Khalaf calls fealty), that is the loyalty to local leaders through the previously mentioned zu'ama system ${ }^{312}$; and c) through religious affiliation ${ }^{313}$. This last form of affiliation is the most significant as it began at the local level and extended right up to the national level; it was the main feature of Lebanon's "curious" confessional political system. It has, in fact become more significant since the decline of the zu'ama system, sustaining the identity and communal solidarity of both families and communities in Lebanon ${ }^{314}$.

\footnotetext{
308 Martin, op. cit., p. 27.

${ }^{309}$ Khalaf, S. (1968). Primordial Ties and Politics in Lebanon. Middle Eastern Studies , 4 (3), pp. 243-269.

310 Ibid, p. 243.

311 Ibid, p. 246.

312 Ibid, p. 253.

313 Ibid, p. 259.

314 Ibid, p. 260.
} 
Geertz also warns that the politicisation of such fundamental associations (which consociationalism and confessional systems invariably do) as being "pathological"315 and refers directly to the case of Lebanon (amongst others) as examples where primordial ethnic identification has directly "[inhibited] a comprehensive civil sense"316. Kanchan Chandra has also argued that primordial conceptualisations of ethnicity, and the relations that result, have often resulted in states that are "less stable, less democratic, less wellgoverned, less peaceful, poor, and marked by slower rates of economic growth"317. Often, Islamist groups have often taken advantage of the capacity gaps left by these weakened states, and used the primacy placed on a primordial identity that concurs with their own, to transcend a nation's borders and advance their own pan-Islamic cause ${ }^{318}$. As we shall see, this happened with the exportation by Iran/importation by Hizbullah of Shi'a revolutionary ideals into Lebanon.

\section{The Iranian Revolution}

As mentioned previously, the emergence of Hizbullah was spurred on by three major influences; the Israeli invasion in 1978, the death of Imam Musa al-Sadr, and the 1979 Shi'a Revolution in Iran. Although al-Sadr had already opened Lebanese Shi'a up to Iranian influence, this Iranian revolution was particularly integral to Hizbullah's early identity, as it accorded with it's own struggles and political possibilities. With the Iranian revolution, the disenfranchised Shi'a in Lebanon become "part of a larger story ${ }^{319 "}$ and were also provided with an inspirational example of a popular Shi'a uprising against a political system that was likewise perceived to be corrupt ${ }^{320}$. The Iranians, themselves, also sought to export their ideas throughout the

315 Geertz, C. (1963). The Integrative Revolution: Primordial Sentiments and Civil Politics in the New States. In C. Geertz (Ed.), Old Societies and New States (p. 310). London: Collier-

MacMillan Ltd, p. 110.

316 Ibid, p. 113.

317 Chandra, op. cit., p. 8.

318 Axtmann, R. (2004). The State of the State: The Model of the Modern State and Its Contemporary Transformation. International Political Science Review , 25 (3), pp. 259-279; cited in Salamey, I., \& Copeland, G., Journal of Balkan and Near Eastern Studies, p. 157. ${ }^{319}$ Ajami, F. (1986). The Vanished Imam. London: Cornell University Press, p. 191.

320 Shanahan, The Shi'a of Lebanon: Clans, Parties and Clerics, p. 108. 
region, and therefore quickly found a willing participant in the, at the time, loose formation, that was Hizbullah. Subsequently Iran was prepared to provide extensive material support to Hizbullah, going so far as to send 1500 Pasdaran, the so-called Revolutionary Guards of the Islamic Revolution, to the Bekaa Valley, to assist in the fight against the Israeli Army ${ }^{321}$. Working under the supervision of the Syrian Army ${ }^{322}$, these guards provided inspiration, training and operational knowledge to the then fledgling militia that was to become Hizbullah ${ }^{323}$.

The 1979 Islamic Revolution in Iran surprised the world and had a profound affect on Muslims in general, and upon Shi'a Muslim in particular. Contrary to the received wisdom on revolutions, where previously they were perceived usually as modernising movements away from religiosity towards a more secular order, the world was now forced to confront a revolution that re-instilled the 'old' ideals of Shi'a orthodoxy, rather than new modernist ideologies ostensibly based upon emancipatory ideologies. Nor did this revolt follow the 'usual pattern' of other classical revolutions that had been the result of economic hardships, lower socioeconomic uprisings, or humiliating military defeats, that were found in the previous revolutions of France, China and Russia ${ }^{324}$. In fact, prior to the revolution Iran had experienced huge economic growth and had found itself an important player within international relations ${ }^{325}$. A year before the revolution, President Carter had toasted Pahlavi, praising his "great leadership", and stating that Iran was "an island of stability in one of the more troubled areas of the world"326. Shah Pahlavi's rule, though despotic, enjoyed the support of the

\footnotetext{
321 Ibid, p. 114.

322 Avon, D., \& Khatchadourian, A. T., op. cit., p. 24.

323 Noe, op. cit., p. 126.

324 Arjomand, S. A. (1989). The Turban For The Crown: The Islamic Revolution in Iran. New York: Oxford University Press, p. 191.

325 Milani, M. M. (1994). The Making of Iran's Islamic Revolution (2nd Edition ed.). Boulder, Colorado: Westview Press, Inc, p. 1.

${ }^{326}$ Carter, J. (1977, December 31). Tehran, Iran: Toasts of the President and the Shah at a State Dinner. Retrieved January 16, 2013, from The American Presidency Project: http://www.presidency.ucsb.edu/ws/?pid=7080
} 
United States of America, Europe, and its own military forces ${ }^{327}$. It appeared consolidated and stable.

This façade belied the insecurity of the Shah's regime, which recognised the frustration of its citizens and the potential for unrest amongst them. It also masked Iran's dire human rights record. In fact by 1975 Iran had the ignominy of having the world's worst human rights record as assessed by Amnesty International ${ }^{328}$. By 1977 opposition had grown, particularly amongst the intelligentsia and working class ${ }^{329}$. Recognising this opposition, and attempting to liberalise as a result, only resulted in unifying an up till now fragmented opposition that was quickly joined by the ulama, the religious leaders of Iran. Due to liberalisation the opposition found itself, for the first time in decades, able to plan rallies and demonstrations against the regime ${ }^{330}$. These public demonstrations quickly spread throughout Iran, capturing the poorer sections of the population. What started as a loose conglomeration of protest movements eventually consolidated into a mass movement mostly under the direction of the ulama $^{331}$. Opposition protests to the modernist secular projects of Shah Pahlavi therefore united under the banner of Shi'a Islam, religion being the only common "discursive medium" that could effectively unify these disparate groups ${ }^{332}$. Ayatollah Khomeini, who was in exile in the holy Shi's city of Najaf, Iraq at the time, and who was being increasingly vilified by the regime, quickly became the symbol of the opposition ${ }^{333}$. Khomeini, unlike moderate factions within the opposition, demanded radical change within Iran. Pahlavi's regime, sensing the preponderance of Shi'a orthodoxy based sentiment began making concessions to appease the opposition. Amongst a plethora of cosmetic changes, the government closed nightclubs and casinos,

\footnotetext{
327 Milani, The Making of Iran's Islamic Revolution, p. 106.

328 Amnesty International. (1975). Annual Report 1974-75. Geneva: Amnesty International.

329 Abrahamian, E. (2008). A History of Modern Iran. New York: Cambridge University Press, p. 155.

330 Ibid, p. 157.

331 Milani, The Making of Iran's Islamic Revolution, p. 112.

332 Emadi, H. (1995, January). Exporting Iran's Revolution: The Radicalization of the Shiite Movement in Afghanistan. Middle Eastern Studies , p. 1.

333 Ibid, p. 113.
} 
established a ministry of religious endowments, restored the Islamic calendar, and began an anti-corruption campaign. These changes, having been demanded by the opposition previously ${ }^{334}$, only succeeded in dividing Pahlavi's camp, weakening its resolve further ${ }^{335}$.

In another act of appeasement, Khomeini was invited back to Iran, but stated that he would not return until Pahlavi was no longer in power. The Ayatollah subsequently increased his hostile attacks against the prevailing regime. In what was to prove a counterproductive move, the Shah requested that Iraq force Khomeini out of the country. Khomeini now went into exile in France and quickly took advantage of the interested Western media and communication channels ${ }^{336}$. Local opposition increased resulting in bloody protests and paralysing strikes. The United States of America, the Shah's main ally, began placing pressure on the Shah to leave, believing that this was a necessary prerequisite for reestablishing order. Shah Pahlavi left Iran in January 1979, but not before establishing an interim government. In early February 1980 Khomeini triumphantly returned to Iran, established his own provisional government. After less than two days of urban fighting, Khomeini's supporters quickly overcame the remnants of Pahlavi's regime. As was to be seen in Lebanon, the Shi'a of Iran found a political voice. The hitherto non-political attitude of Shi'a was roused and their leaders were to find that they had acquired political power ${ }^{337}$. On the $1^{\text {st }}$ of May 1979 Ayatollah Khomeini declared the establishment of the Islamic Republic of $\operatorname{Iran}^{338}$, and as a result two and a half thousand years history of monarchy in Iran had been replaced by an Islamic order based on Shi'a principles ${ }^{339}$.

\footnotetext{
334 Abrahamian, op. cit., p. 158.

335 Milani, The Making of Iran's Islamic Revolution, p. 117.

336 Ibid, p. 118.

337 Borghei, M. (1992). Iran's Religious Establishment: The Dialectics of Politicization. In S.

K. Farsoun, \& M. Mashayekhi (Eds.), Iran: Political Culture in the Islamic Republic (p. 269).

Arbington, Oxon, England: Routledge, p. 77.

338 Milani, The Making of Iran's Islamic Revolution, p. 154.

339 Abrahamian, op. cit., p. 162.
} 
Modern Western incarnations of constitutionalism are broadly based on the separation of state powers, the limiting of those powers, as well as the protection of certain rights for citizens. In the West a usual feature of these constitutions has been the separation of religion and state ${ }^{340}$. For the West, the modern incarnation of this separation has largely existed since the Reformation. This has not been the case in the Islamic world where religion has permeated the day-to-day lives of the people to a much greater degree. Thus, it is not surprising that the constitution subsequently formulated by Khomeini and his associates not only rejected such division, but also placed the state subordinate to the Shi'a faith ${ }^{341}$. And while there were some within the inner circle who were advocating for a constitution based more on the western notions, particularly those from de Gaulle's Fifth Republic in France $^{342}$, this was rejected outright by Khomeini who stated that the constitution was to be purely Islamic, not bearing any inspiration from either the West or East. This constitution, among other articles, advocated for the 'disinherited', spurned any explicit influence from neither the West/Capitalism nor East/Socialism, nor any alliance with the superpowers, nor accepted any imperialistic intrusions into its sovereignty ${ }^{343}$. All of these elements would ultimately be found in the Hizbullah's 'Open Letter', its founding document.

Khomeini was to be at the middle of this new constitution, being designated as the supreme Faqih, expert on Islamic affairs, answerable only to God, as well as the Marja'-e Taqlid ${ }^{344}$, the highest authority within Shi'a Islam. As such, the constitution was to institutionalise the Velayat-e Faqih ${ }^{345}$, the pronouncements of Khomeini, which were considered beyond reproach ${ }^{346}$.

\footnotetext{
340 Milani, M. (1992). Shi'ism and the State in the Constitution of The Islamic Republic of Iran. In S. K. Farsoun, \& M. Mashayekhi (Eds.), Iran: Political Culture in the Islamic Republic (p. 269). Arbingdon, Oxon, England: Routledge, p. 133.

341 Ibid, p. 134.

342 Abrahamian, op. cit., p. 162.

343 Milani, The Making of Iran's Islamic Revolution, p. 156.

${ }^{344}$ Marja'-e Taqlid literally means 'source of imitation' in both Arabic and Persian. The inference being that the Ayatollah is to be emulated by followers.

345 Velayat-e Faqih (Persian transliteration) means the same as Wilayat al-Faqih (Arabic transliteration) (see Footnote 196).

346 Abrahamian, op. cit., p. 162.
} 
This authoritarian approach concurred with Shi'as' history of accepting minoritarian rule; hence it further consolidated their propensity towards political quietism, and the refusal "to admit that majority opinion is necessarily true or right"347. That this did not accord with democracy was not particularly problematic for Khomeini; Islam was considered as political perfection and democracy was little more than a Western conceit. The Velayat-e Faqih was essentially considered to be the voice of God, and the masses were expected to have faith in the clergy. Apparently they did; the new Islamic Constitution was put to a public referendum in 1979 and 99 per cent voted 'yes'348.

The Islamic Constitution established in Iran clearly indicates Iran's vision of pan-Shi'ism and the desire to export the Islamic Revolution into Lebanon ${ }^{349}$. As such it was to largely define the principles and organisation of Hizbullah. Khomeini's vision of the revolution called for the unity of all Muslims and did not recognise sovereign borders, which it perceived, particularly in the Middle East, to be the implementation of West's Westphalian system. As per its constitution, Iran aligned itself with other liberation struggles outside of the country, particularly those in neighbouring countries ${ }^{350}$. The struggle of Shi'a in neighbouring Lebanon was an obvious focus.

While both Syria and Iran were early patrons of Hizbullah, Syria's patronage was more strategic in that Hizbullah's emergence serendipitously aligned with Syria's designs in the region. That is, Hizbullah's existence allowed Syria to align itself strategically with Iran, and to further its influence within Lebanon. And while Iran had assisted the Shi'a community in Lebanon in the past largely through the Amal movement, Tehran had never been completely satisfied with Amal's moderate politics and secularism. This was primarily because the movement wasn't guided by the ideals pan-Shi'ism or pan-Islamism and did not sufficiently seek to advance the Islamic

\footnotetext{
${ }^{347}$ Enayat, H. (2005). Modern Islamic Political Thought. London: I. B. Tauris \& Co Ltd, p. 19.

${ }^{348}$ Abrahamian, op. cit., p. 168.

${ }^{349}$ Avon, D., \& Khatchadourian, A.-T., op. cit., p. 23.

350 Emadi, op. cit. , p. 2.
} 
Revolution $^{351}$. It would not be until the emergence of Musawi's Islamic Amal, and Hizbullah's subsequent emergence, that Iran would see its ideological manifestation of pan-Islamism writ large 352 .

Iran's patronage also accorded with Hizbullah's strategic interests. Lebanon's sectarian groups have had a history of aligning themselves with external powers, and inviting their influence into the Lebanese arena to assist in balancing the respective group's power against others. This was particularly the case with Shi'a Muslims and Maronite Christians who, unlike the Sunni Muslims, needed to align with external powers to find security ${ }^{353}$. The westward facing Maronites had therefore relied on French patronage as well as that from other Western states. The Sunni Muslims, who regionally were in the majority, had appealed to Arab nationalism and therefore relied on Lebanon's neighbours for empowerment. However, whereas the Shi'a had largely lacked such a patron, one was now found in Iran ${ }^{354}$. Hizbullah therefore accepted generous funding from Iran ${ }^{355}$. Estimates place Iran's funding of Hizbullah in the 1980s, especially in its formative years, as being between five to ten million US dollars a month. Although this funding decreased as Hizbullah become more self-sufficient, Iran still significantly funds the organisations military wing in particular ${ }^{356}$. In addition to this Hizbullah fully embraced the Wilayat al-Faqih of Khomeini ${ }^{357}$, and accepted him as their Marja' al-Taqlid ${ }^{358}$. Moreover, Hizbullah mutually identified with the common revolutionary Shi'a struggle against imperialistic forces, as well as against the Zionism of Israel ${ }^{359}$. It is therefore not surprising that the

\footnotetext{
351 Norton, Amal and the Shi'a, p. 141.

352 Norton, Hezbollah: A Short History, p. 35.

353 Norton, Amal and the Shi'a, p. 141.

354 Ajami, The Vanished Imam, p. 205.

355 Norton, Amal and the Shi'a, p. 106.

356 Wege, C. A. (1994). Hizbollah Organisation. Studies in Conflict and Terrorism , 17, p. 158;

cited in Shanahan, R. (2003). Radical Islamist Groups in the Modern Age: A Case Study of Hizbullah. Australian National University, Strategic \& Defence Studies Centre. Canberra: Australian National University, p. 12.

357 Alagha, The Shifts in Hizbullah's Ideology: Religious Ideology, Political Ideology, and Political Program, p. 141.

358 Ibid, p. 112.

${ }^{359}$ Avon, D., \& Khatchadourian, A.-T., op. cit., p. 25.
} 
already mentioned 'Open Letter to the Disinherited' mirrors elements found in Iran's constitution and bears strong Iranian influence ${ }^{360}$.

\section{The 'Open Letter' of 1985}

Although Hizbullah was established in 1982, it was a relatively clandestine organisation until 1985 when it published its 'Open Letter to the Disinherited'. This letter publicly announced the arrival of Hizbullah to the coterie of other militia within Lebanon. It is largely rooted in Shi'a ideology and is marked by revolutionary fervour. It therefore unanimously agrees with the views of post-revolution Iran. Having said that, it also indicates the organisations attempts to "don a cloak of pragmatism and moderation ${ }^{361 ",}$ for Hizbullah had realised at this nascent stage that the political realities of Lebanon would severely limit its revolutionary aspirations. Hizbullah's pragmatism was a short-term consideration, whereas the revolutionary elements within the document were better viewed as long-term goals. It's content can be broadly delineated as follows:

1) It calls for an Islamic state within Lebanon. The document explicit rejects the confessional system that currently prevails in Lebanon and calls for it to be replaced by one that mirrors Iran's revolutionary republic. Interestingly, this is where the documents ends on this matter; just as it is vague on defining what the organisation perceives to be the problems of the current system, it is also vague on suggesting improvements or on what type of political arrangement Hizbullah would like to see installed ${ }^{362}$, although one could assume that this would no doubt be under clerical rule along the lines of Iran's theocratic system. Ultimately the organisation hopes for this to be achieved through the free choice of the Lebanese and not through

\footnotetext{
${ }^{360}$ Norton, Hezbollah: A Short History, p. 35. A good English translation of this manifesto can also be found with Joseph Alagha's Hizbullah's Documents: From the 1985 Open Letter to the 2009 Manifesto (pages 39 to 55). An alternative translation can be found in Avon \& Katchadourian's Hezbollah: A History of the "Party of God" (pages 103 to 129). 361 Zisser, E. (2003). Hizballah. In B. Rubin (Ed.), Revolutionaries and Reformers: Contemporary Islamist Movements in the Middle East (pp. 91-103). New York: State University of New York Press, p. 93.

362 Shanahan, The Shi'a of Lebanon: Clans, Parties and Clerics, p. 115.
} 
imposition ${ }^{363}$. As such, it is an example of Hizbullah's long-term revolutionary ideals coming to terms with Lebanon's practical realities;

2) It divides the world between the oppressors and the oppressed. While this dichotomy naturally lends itself to a Marxist socioeconomic class distinction, this is not necessarily the exclusive explanation intended by Hizbullah, although it does apply; a Quranic interpretation places this division at a more existential level. Therefore, it is a segregation that transcends "class, cultural, and religious cleavages" 364 , and can be understood as those oppressed by imperialism, those oppressed by Zionism, those Lebanese citizens oppressed by the state ${ }^{365}$, as well as those subjected to the $z u^{\prime} a m a$ system;

3) It is anti-Zionist. Hizbullah is clear on this point. Israel is the "spearhead of America" and a "rapist enemy" 366 that must be annihilated. It is a colonial power that is occupying Muslim land and oppressing Muslims. Moreover, it perceives Zionism to be an expansionist philosophy 367 , hence its intense opposition to the Christian Phalange, who were in alliance with Israel and thus seen as Zionism writ large within Lebanon ${ }^{368}$. Despite this, the document also explicitly claims that Hizbullah it is not anti Jew, and that it would accord them their civic and human rights as stipulated within the Quran $^{369}$. However, Jews living in Israel were, by definition, primarily seen as Zionists before anything else, and therefore not eligible for such charity;

\footnotetext{
363 Hamzeh, op. cit., p. 145.

364 Alagha, Hizbullah's Documents: From the 1985 Open Letter to the 2009 Manifesto, p. 16.

365 Avon, D., \& Khatchadourian, op. cit., p. 184.

366 Alagha, Hizbullah's Documents: From the 1985 Open Letter to the 2009 Manifesto, p. 48.

367 Shanahan, The Shi'a of Lebanon: Clans, Parties and Clerics, p. 115.

368 Alagha, Hizbullah's Documents: From the 1985 Open Letter to the 2009 Manifesto, p. 43.

369 Ibid, p. 19.
} 
4) It is pan-Islamic. Hizbullah sees the Sunni-Shi'a division as the result of what was initially a result of a Western conspiracy but is now being perpetuated by local elites, corrupt religious scholars, and those within the $z^{\prime}$ 'ama system ${ }^{370}$. Because of this it seeks to overcome this cleavage in order to present a united front against the West;

5) It is anti imperialist. Hizbullah viewed the Islamic world-view as the only true narrative, and thus rejected the importation of alternative ideologies, especially the Western conception of capitalism that America embodied. Over and above this, Hizbullah in fact rejected any materialistic conception of the world, favouring a more holistic view that also embraced a more spiritualist conception ${ }^{371}$. It followed then that it also rejected socialism, and the possibility of influence from the Soviet Union. Hence Hizbullah's particularly vehement opposition to the Lebanese Communist Party ${ }^{372}$; and

6) It extols jihad and martyrdom. Hizbullah saw martyrdom, resulting from engaging in jihad, as a way of overcoming the asymmetrical power imbalances inherent in fighting both imperialist forces and those who were better trained and equipped. In its interpretation, martyrdom was a weapon of the oppressed ${ }^{373}$, and indeed, as mentioned previously, Hizbullah's use of this, combined with its use of guerrilla warfare, presented its foes with a formidable force to be reckoned with. Hizbullah's foot soldiers' readiness to die (martyrdom) for the struggle (jihad) caught many other militia off guard, and went some way to ameliorating the shortcomings the organisation might have initially had in regards to resources and training.

\footnotetext{
370 Ibid, p. 53.

371 Ibid, p. 20.

372 Norton, Hezbollah: A Short History, p. 37.

373 Avon, D., \& Khatchadourian, A. T., op. cit.
} 
First and foremost, it is a vision of an Islamic State within Lebanon that largely defines the subsequent elements of the letter. Moreover, this vision largely transcends Lebanon, and is an appeal to the Islamic World in general, if not further afield ${ }^{374}$. Yet even by the time of the letter's publication Hizbullah recognised that the idea of an Islamic state in Lebanon would be vehemently opposed by practically half of the country's population, namely Christians, a portion of the population who would then be subjected to sharia law. Therefore, while not explicitly dispensing with this idea completely, nor its Shi'a ideological orientation, the organisation was to significantly downplay this aspect. As the organisation moved away from this Shi'a revolutionary identity and repositioned itself as a nationalistic resistance movement, it would subsequently express this significant portion of the population as 'partners'375.

\section{The Instrumentalist Turn in Hizbullah's Identity}

Instrumentalist approaches to ethnic identity directly oppose primordialist accounts in that they perceive these identities to be multiple and changeable. Chandra points that "ethnic identities are not singular, nor are they fixed", citing examples of ethnic groups as diverse as the native American population, Muslims in Bosnia, the Kanyan in Sri Lanka, and even the English in Britain ${ }^{376}$, all of whom have adopted malleable concepts of ethnicity as they have seen expedient.

Whereas primordial approaches consider identity to be fixed and immutable, instrumentalist approaches assert that ethnic identity is variable as it is defined and strengthened by material and politically expedient considerations. Here, shared interests and identity play a utilitarian role in defining both an individual's, a group's, or a community's method of

374 Khatib, L. (2011). Hizbullah's Political Strategy. Survival: Global Politics and Strategy , 53 (2), p. 62.

375 Alagha, The Shifts in Hizbullah's Ideology: Religious Ideology, Political Ideology and Political Program, p. 202; cited in Khatib, op. cit., p. 66.

376 Chandra, op. cit., p. 4. 
identification $^{377}$. Anthony Smith examines ethnic identification processes along these lines. Instrumentalist interpretations of ethnicity are often adopted or modified by the group, or commonly by elites who often "construct group consciousness" 378 to achieve particular political outcomes $^{379}$. Smith relates this to consociationalism in that that political system attempts to allow the continuance of ethnic pluralism within the realm of politics, nominally as a means of facilitating the representation of different ethnic identities and thereby avoiding ethnic conflict. However, he also demonstrates how instrumentalist approaches can also then foster continual division in that elites often use ethnic identity to their own selfregarding ends.

Instrumentalism may, therefore, go some way to explaining the lack of nationalism, or national identity, in Lebanon, where religious elites have continually avoided cross-community representation, "[establishing] a divide-and-rule strategy to secure their power" ${ }^{380}$. Hizbullah took advantage of this lack of a nationalistic identity in Lebanon, and concentrated on adopted an instrumental identity, namely that as a resistance movement, rather than their primordial Shi'a identity.

With the end of the civil war, and the implementation of the Taif Accord, Hizbullah found that it had to downplay its ideological roots and Shi'a identity, in order to participate effectively in national politics. Hizbullah recognised that for this to take place, it was going to require popular support from both Shi'a and non-Shi'a alike. Moreover, the 'rules of the game' had shifted and patronage from regional powers was no longer a guarantee of local power. By the mid-1990's Hizbullah had lost a large amount of patronage from its two regional benefactors, Syria and Iran. Syria

\footnotetext{
377 Hempel, L. (2004). What's It Worth To You? The Questionable Value of Instrumentalist Approaches to Ethnic Identification. International Journal of Comparative Sociology , 45 (34), pp. 253-275.

378 Jesse, N. G., \& Williams, K. P. (2010). Ethnic Conflict: A Systematic Approach to Cases of Conflict. Washington: QC Press, p. 12.

379 Smith, A. (2010). Nationalism: Theory, Ideology, History. Cambridge: Polity.

380 Martin, op. cit., p. 27.
} 
was to eventually withdraw from Lebanon (and is now currently embroiled in its own civil strife), and since then has been unable to exert the authority over the organisation that it once could ${ }^{381}$. In addition to this, Iran's patronage of Hizbullah was also wavering by the early 1990's, and the organisation could no longer be seriously considered to represent Iran's regional aspirations within Lebanon ${ }^{382}$. Iran, on the other hand had also shifted its focus from exporting the revolution to concentrating on its own national interests. The death of Ayatollah Khomeini in 1989 saw the ideological fervour of the revolution replaced by more pragmatic matters concerning what needed to be done locally. This was particularly pertinent as Iran had just emerged from its war with Iraq the previous year. Hizbullah's ideological identity as the dominant representative of Shi'a would need to be succeeded by one that accentuated its resistance capabilities. Yet, with the withdrawal of Israel from Southern Lebanon in May 2000, Hizbullah found that its justification as a resistance movement had become contentious. As mentioned previously, the justification for this was found in the issues around Israel's occupation of Shebaa Farms, which it claimed was still occupied Lebanese land.

\section{The 'New Manifesto’ of 2009}

At a news conference on the 30 November 2009, Sayyed Hassan Nasrallah announced the release of a new document essentially outlining Hizbullah's new political position. This surprised many political commentators, as it was only the second "ideological platform" released by Hizbullah since its formulation in $1982^{383}$. While not actually present (Nasrallah was at an undisclosed location connected via a televised link), Nasrallah proceeded to read out this new document that has become largely known as the 'New Manifesto'. And while Nasrallah stated that the manifesto indicated a more pragmatic organisation, he also stressed that Hizbullah still retained a Shi'a

\footnotetext{
381 Hamzeh, op. cit., p. 146.

382 Norton, Hezbollah: A Short History, p. 44.

383 Berti, B. (2010). The "Rebirth" of Hizbollah: Analyzing the 2009 Manifesto. Strategic Assessment, 12 (4), p. 91.
} 
ideology directly tied to the clerical direction of $\operatorname{Iran}^{384}$. Despite this assertion there was a noticeable decrease in Islamic rhetoric, which in the 'Open Letter' was an overtly Iranian influence in any case (for example America was no longer defined as the "great Satan" but was spoken of in terms of hegemonic power, etc.). Displaying continuity in some areas, the New Manifesto also outlined a radically different position in regards to Hizbullah's relation to the rest of Lebanon, and overall the entire manifesto was defined by a sense of moderation and a more politically aware nuance. The stated purpose of the manifesto was to officially state Hizbullah's political position now that it had become an integral political player within Lebanon. The document, which was generally marked by a more diplomatic tenor, also sought to place Hizbullah in the international arena. An arena that Hizbullah claimed had significantly changed since its inception, which was mostly because of a supposed decline in American hegemony and the subsequent rise in resistance movements ${ }^{385}$. Hizbullah considered itself, along with other resistance movements around the world, as

“... an essential strategic fact in this global landscape, having played a central role in the developments or in the impetus for changes that have occurred in our region [sic]". ${ }^{386}$

Basically the document's view of the world was one of imperialistic powers oppressing the Third World. Therefore, as opposed to the 'Open Letter', particular emphasis was placed on this dichotomous view of the world and Hizbullah's jihadist approach to resistance against Israel ${ }^{387}$. Here, in the organisation's view, the former justifies the later.

\footnotetext{
${ }^{384}$ Ladki, N. (2009, November 30). Hezbollah Cuts Islamist rhetoric in new manifesto. Retrieved January 20, 2013, from Reuters: http://www.reuters.com/article/2009/11/30/us-lebanon-hezbollahidUSTRE5AT3VK20091130

385 Avon, D., \& Khatchadourian, A. T., op. cit., p. 130.

386 Ibid, p. 132.

387 Ibid, p. 5.
} 
The document was divided into three main chapters $388:$ 1) "Hegemony and Mobilisation", which warned against foreign influence, especially that of the United States of America, and basically constituted Hizbullah's 'foreign policy'; 2) "Lebanon", which examined Hizbullah's relation to the rest of the nation, that is its 'domestic policy'; and 3) "Palestine and the Settlement Negotiations", which covered the ongoing Arab-Israeli conflict.

Hizbullah's foreign policy is mostly outlined in Chapter 1; however, aspects of foreign relations are also covered in Chapter 2 (in regards to its, and Lebanon's, relations to Iran and Syria) and Chapter 3 (outlining Hizbullah's relations to Israel and the Palestinian movements). Regarding foreign relations, there is little difference from Hizbullah's relations with external powers in the 1985 'Open Letter'389. Hizbullah still retains the oppressor and oppressed dichotomy and an anti-Western stance, except now America is, after the Cold War, the imperialistic power par excellence. America, for Hizbullah, represents the capitalist system that is responsible for a pernicious globalisation that causes "cultural, economic and societal pillage" particularly in the Third World ${ }^{390}$. In addition, a post-9/11 America has equated terrorism with national resistance, thereby justifying more overt military action within states such as Afghanistan and Iraq. Thus Hizbullah still claims that the Middle East in particular has suffered the most under this American domination, due to America fostering interstate as well as inter-sectarian discord throughout the region. Zionism, supported as it is by American foreign policy is, accordingly, a manifestation of this hegemonic incursion into the region ${ }^{391}$.

\footnotetext{
388 Translations of this manifesto can be found in both Alagha's Hizbullah's Documents: From the 1985 Open Letter to the 2009 Manifesto, and Avon \& Khatchadourian's Hezbollah: A History of the "Party of God".

${ }^{389}$ Berti, The "Rebirth" of Hizbollah: Analyzing the 2009 Manifesto, p. 95.

390 Alagha, Hizbullah's Documents: From the 1985 Open Letter to the 2009 Manifesto, p. 119.

391 Ibid, p. 121.
} 
Despite this document's continuity with the 'Open Letter', it also reveals a more nuanced knowledge of international relations and an awareness of the exigencies of political participation in the region. Its use of terms like "antiglobalisation" displays the realisation by Hizbullah that the rhetoric of the past will not be conducive to being a regional political participant ${ }^{392}$. Moreover, Hizbullah also displays a more global reach by identifying itself with nationalistic movements fighting oppression in the Islamic World, and as far afield as Latin America.

In regards to the region, Hizbullah prefers that Lebanon's relationship with Syria is one that is "privileged" and "distinguished"393. Interestingly, and contrary to the 'Open Letter', while the New Manifesto acknowledges the vital role that Iran plays in the region, there is a conspicuous absence of any mention of Iran's relation to Hizbullah. In fact, Khamenei (the current ayatollah in Iran), and Hizbullah's adherence to his wilayat al-faqih, are only mentioned once within the document. Where they are mentioned, it is only in passing and to acknowledge Iran's continual support (a much more passive method of reference opposed to the much more active use of 'patronage') ${ }^{394}$. While this might be an indication that Hizbullah is trying to position itself as a Lebanese movement first, that serves the national interest $^{395}$, there has nevertheless been a distinct movement away from relying upon Iran in the organisation's decision-making process.

The second chapter of the manifesto contrasts the most with the 'Open Letter'. While not explicitly stating such, there is no longer any mention of wanting to establish an Islamic state within Lebanon. Although, to be fair, Hizbullah had been giving this goal a lower profile since it started to politically participate in 1992. Then it had stated that, while it had not theoretically relinquished this goal, it was a more ideologically driven vision that did not sit well with the earthly reality of participating in local

\footnotetext{
392 Berti, The "Rebirth" of Hizbollah: Analyzing the 2009 Manifesto, p. 94.

${ }^{393}$ Alagha, Hizbullah's Documents: From the 1985 Open Letter to the 2009 Manifesto, p. 130.

394 Avon, D., \& Khatchadourian, A.-T., op. cit., p. 152.

395 Berti, The "Rebirth" of Hizbollah: Analyzing the 2009 Manifesto, p. 94.
} 
politics ${ }^{396}$. Regardless of this, Hizbullah still retains the position that the system needs to be radically altered, or rather that it should be more in keeping with the demands of the Taif Accord of 1989397. That is, that the confessional system of political representation needed to be replaced (although no serious attention has been paid to this matter by the government since). Hizbullah believed consensual democracy should take its place, stating:

"[It] is an appropriate blueprint for achieving real participation by all. It represents a confidence factor for national constituencies, and significantly contributes towards paving the way for building the reassuring state that all citizens would feel has been built for them." 398

It is this last point that reveals Hizbullah's confidence as an ongoing participant in Lebanon's political system. By being prepared to subject itself to consensual democratic processes, whatever the outcome, Hizbullah still retains influence whether in the opposition or not ${ }^{399}$.

Further in this chapter dealing with Hizbullah's relationship with the rest of the nation, it turns to its role as a resistance movement. The document reminds the reader that

“[Hizbullah's] armed resistance [against Israel] was launched as a goal, especially in light of the... occupational circumstances and the absence of a capable Lebanese state". 400

The organisation then reasserts its role as a resistance movement and makes it clear that it has no intention of surrendering its arms (contrary to the Taif Accord), leave alone even discussing the issue of disarmament ${ }^{401}$. Hizbullah states that it is not only potential aggression from Israel, but also their continual occupation of the Shebaa Farms in the Golan Heights, that necessitates this ${ }^{402}$. Further to this, it reminds the Lebanese state of its

\footnotetext{
396 Ibid, p. 96.

397 Alagha, Hizbullah's Documents: From the 1985 Open Letter to the 2009 Manifesto, p. 32.

398 Ibid, p. 126.

${ }^{399}$ Berti, The "Rebirth" of Hizbollah: Analyzing the 2009 Manifesto, p. 97.

400 Alagha, Hizbullah's Documents: From the 1985 Open Letter to the 2009 Manifesto, p. 124.

401 Berti, The "Rebirth" of Hizbollah: Analyzing the 2009 Manifesto, p. 97.

402 Alagha, Hizbullah's Documents: From the 1985 Open Letter to the 2009 Manifesto, p. 125.
} 
military inferiority to that of Israel. Hizbullah does acknowledge the legitimacy of the Lebanese Army, and acknowledges that while they both essentially have the same goal (the strategic and security interests of Lebanon), Hizbullah's refines its specific role as that of a resistance movement that principally resists Israel, whereas the Lebanese Army secures the state's overall stability ${ }^{403}$. As such Hizbullah explicitly rejects those calls for its dissolution, or its assimilation into the Lebanese Army, while retaining the possibility of cooperating with the army in some form of national strategy ${ }^{404}$.

The moderated language of the last chapter, dealing with the Arab-Israeli conflict and the Palestinian cause, barely masks the organisation's continual contempt for Israel, and its continual existence. There is no policy shift here, and Hizbullah still anticipates Israel's eventual annihilation, although now it articulates it in language that is perhaps more acceptable within the realm of international relations. The document states:

"The Zionist movement is a racist movement both in terms of thought and practice... The struggle that we and our nation undertake against the Zionist-colonialist plan for Palestine is but a duty of self-defence against occupation, aggression and the hegemonic Israeli oppression, a threat to our very existence and a menace to our rights and future". ${ }^{405}$

Hizbullah considers Israel's existence as a direct threat to Lebanon ${ }^{406}$ and thus Zionism is again used to bolster Hizbullah's standing as a resistance movement, and by extension its continual armament. Moreover, the organisation equates Israel's occupation of the Shebaa Farms with its occupation of Muslim land (that is, Palestine). A reckoning that equates Hizbullah's resistance with the armed struggle of Palestinians ${ }^{407}$. From this viewpoint, Hizbullah absolutely rejects any peace settlement process with Israel. As long as Israel exists,

\footnotetext{
403 Ibid, p. 125.

404 Ibid, p. 125.

405 Ibid, p. 133.

406 Berti, The "Rebirth" of Hizbollah: Analyzing the 2009 Manifesto, p. 95.

407 Alagha, Hizbullah's Documents: From the 1985 Open Letter to the 2009 Manifesto, p. 136.
} 
Hizbullah will oppose it. Hence, after Israel's withdrawal from Lebanon, its existence still justifies Hizbullah's raison d'être and defines its identity. In fact, in so far as Hizbullah is now prepared to support foreign resistance movements, it attempts to guarantee its own future. 


\section{Conclusion}

With seventeen separate religious groups, Lebanon was from its inception beset by the self-interest of these groups and therefore lacked a cohesive national identity. This was most marked when considering the divide between the Christian and Muslim groups, with each half orientated towards either the West or the East respectively. Shi'a Muslims in particular, sensing the potential for political representation separate from Sunni Muslims, as well as release from the oppressive zu'ama system, were relatively supportive of this new arrangement. The power positions of the various dominant confessions were solidified with the formation of an ostensibly consociational political system of governance codified in the National Pact of 1943. Based on the already obsolete census results of 1932, this system granted both Maronites and Sunni Muslims the Presidency and Prime Ministership respectively. Shi'a, the third largest religious group and the most socioeconomically deprived confession within the state, were given the relatively ineffectual position of Speaker of the House.

The internal divisions of the state were further exacerbated by external influences by the early 1970s. With the presence of large numbers of Palestinian refugees and militias now in the country, Lebanon found itself the target of Israeli aggression. This aggravated the already fraught tensions between Christians and Muslims, and by 1976 the country had devolved into civil war. Israel's occupation of Southern Lebanon in 1978 furthered the already nascent politicisation of Shi'a Muslims, which eventually led to the formation of Hizbullah in 1982. Hizbullah therefore emerged out of an environment that was beset by sectarian violence and a weak state presence. Initially it represented the Shi'a community, and as such also represented this community's entry into the civil war, although, unlike other sectarian factions, the organisation's raison d'être was perhaps more focussed; the removal of the Israeli occupation, as well as the establishment of an Islamic State in Lebanon. Although this last goal ostensibly represented the interests of Muslim's in general, it was essentially the 
continuance of the Iranian Revolution, and its importation into Lebanon. The concurrent 1978 Shi'a Revolution in neighbouring Iran was to provide both inspiration and guidance for this organisation, and to prove integral to forming the group's initial identity. Previous Shi'a political groups in the country, particularly Amal, had believed modernist secular ideals would aid Shi'a Muslim advancement. But in recognising the importance of primordial identities within Lebanon, and guided by Iran, Hizbullah embraced its Shi'a identity and based its initial political platform on this, as evidenced in the 'Open Letter' of 1985. This document, among other things, called for the removal of Israel from Lebanon, that country's ultimate annihilation, as well as an Islamic revolution in Lebanon, presumably one that would mirror that of Iran.

Hizbullah experienced the implementation of the Taif Accord and the end of the civil war with relative indifference; the accord had made constitutional changes in Shi'a Muslim's favour, largely due to them now being the majority, but the organisation mostly viewed these as inconsequential. In addition, Israel still occupied Southern Lebanon, thus, unlike other militias, and as per the demands of the accord, Hizbullah refused to disarm. Further to this, for Hizbullah to obtain any influential foothold within the state it would need to begin participating in the political system of the country. This was further necessitated by the reduction in patronage by Iran following the death of the Ayatollah Khomeini in 1989 and Iran's concentration on its internal problems following the end of its war with Iraq in 1988. This would mean that its Shi'a identity could no longer be the central determinant of how the organisation would act and represent itself within Lebanon. Retaining its belief that the confessional political system in Lebanon was corrupt, the organisation nevertheless recognised that it could only change it by active participation. The group also recognised that participation in the political system would also need broad-based support from both Shi'a and non-Shi'a. It sought to achieve this by moving away from an identity that aligned it mostly with its Shi'a constituents, and sought to present itself as a resistance group that was the only organisation within 
the country that could viably counter Israeli aggression. This identity, which was instrumental in nature, achieved two goals for the organisation. Firstly resistance to Israel had popular support throughout Lebanon and could be presented as a nationalistic goal; it therefore went someway to ameliorating any apparent contradictions in being an armed group also participating in politics. Secondly, it legitimised the group's retention of arms contra the Taif Accord.

With the withdrawal of Israel from Southern Lebanon in 2000, Hizbullah's resistance identity became less feasible. Israel's occupation of Southern Lebanon had been the establishing raison d'être of the organisation, and the very foundation of its resistance identity. Recognising the importance of this instrumental identity, the organisation essentially 'recalibrated' it in two ways. Firstly, by concentrating on Israel's apparent occupation of Shebaa Farms, which it considered to be Lebanese land. Secondly, the organisation also aligned itself with other resistance movements throughout the world, but particularly Palestinian movements, such as Hamas. The organisation has since continued with this identity as evidenced in the 'New Manifesto' of 2009. This document was marked by a significant decrease in revolutionary language that in the past had directly linked the group to the ideology imported/exported from the Shi'a revolution in Iran. It is also more diplomatic, and displays an awareness of the political reality in Lebanon. Despite this, the document still places primacy on Hizbullah's identity as a resistance movement, but this time not only reminding the nation of Israel's aggression, but of its own army's inadequacy in countering this.

This resistance identity may not be enough to sustain Hizbullah, and may in fact be counter productive to its future prospects. Up till now, the organisation has been able to focus this resistance identity towards Israel, both directly, and by supporting Hamas and other Palestinian groups. That Hamas is a predominantly a Sunni movement has not been problematic for Hizbullah, as both shared a mutual aggressor. However, the organisation 
has also supported other recent uprising in Tunisia, Yemen, Bahrain, Egypt, and Libya, all of which have been part of the so-called 'Arab Spring'408. Starting first in Tunisia in late 2010, these uprisings spread through Northern Africa and the Middle East, unbalancing the status quo and catching many of the political regimes off guard.

Support of these uprisings by Hizbullah was indicative of its strong political position within Lebanon by 2011. Earlier in that year, in response to the UN Special Tribunal's attempts to indict members of Hizbullah it believed were responsible for Rafiq Hariri's assassination six years before, two of its ministers and eight others aligned with them, resigned from the cabinet. Hizbullah had effectively orchestrated the collapse of the government under Saad Hariri, the son of Rafiq, in an attempt to stop these indictments ${ }^{409}$. With the subsequent establishment of a new government under Najib Mikati, who was nominated by the March 8 Alliance ${ }^{410}$, of which Hizbullah is the dominant constituent, the organisation found itself at the political centre in Lebanon ${ }^{411}$. Yet, the organisation has subsequently squandered much of its legitimacy in its contradictory approach towards the various political revolutions taking place throughout the region.

As the various uprisings in the 'Arab Spring' invariably heralded the rise of Islamist parties, much like itself, Hizbullah tended to be in full support of them. Hizbullah has viewed these public demonstrations for regime change as anti-imperialistic movements, as in the case of Egypt, which it perceived to be a 'puppet' of America. Many of the 'Arab Spring' uprisings have therefore resonated with its current ideology of resistance ${ }^{412}$. However, in

\footnotetext{
408 Berti, B. (2012). Hizbullah, Hamas, and the "Arab Spring" - Weathering the Regional Storm? Israel Journal of Foreign Affairs , 6 (3), p. 22.

${ }^{409}$ Khatib, L. (2011). Hizbullah's Political Strategy. Survival: Global Politics and Strategy , 53 (2), pp. 61-76.

410 The 'March 8 Alliance' has been the ruling coalition in Lebanon since 2011. The name stems from the date of 2005 demonstrations in Beirut that sought to counter the so-called Cedar Revolution rallies (these in turn were in response to Rafiq al-Hariri's assassination). The alliance includes both Hizbullah and the Amal Movement, but is not necessarily a Shi'a alliance as it also includes other confessional and secular groups.

411 Berti, Israel Journal of Foreign Affairs, p. 22.

412 Ibid.
} 
the case of the current strife in Syria, the organisation has arbitrarily disregarded its resistance agenda and sided with the current ruling regime in Syria. Hizbullah's has been both vocal in its support of, and ready to provide material aid to, the embattled Alawi regime in that country. Hizbullah appears to have disregarded its resistance ideology for the sake of strategic interests. The possibility of a Sunni regime replacing the current Shi'a Alawi minority regime in Syria would mean that the organisation would also be faced with the substantial loss of a significant patron. In addition to this, the organisation would also loose its physical connection to Iran, with much of its material support from Iran being transported through Syria 413 .

This support of the regime in Syria has meant that Hizbullah has lost a large amount of respect and legitimacy within Lebanon, the region, and internationally. Locally, the organisation has lost large amounts of political legitimacy. Long positioning itself as the champion of the 'Arab Street', public demonstrations, particularly those led by Sunni Muslims, in these socalled streets within Lebanon have openly decried Hizbullah for siding with a dictator. Sunni groups within Lebanon have sided with Syrian rebels, which in turn have increased tensions with Hizbullah and Shi'a Muslims in general $^{414}$. This is not the usual astute pragmatism that is usually associated with Hizbullah, and its support of Assad's regime may be a panicked reaction that is perhaps indicative of organisation that realises that it is under siege. Nasrallah, the Secretary General of Hizbullah, has responded to these accusations of double standards by asserting, perhaps speciously, that the Syrian conflict is qualitatively different from the other uprisings; Syria is the only country that is openly opposed to the United States of America and Israel's alliance, and that the rebellion is due to the influences of these

\footnotetext{
413 Filkins, D. (2013, February 25). After Syria: If the Assad regime falls, can Hezbollah survive? The New Yorker, p. 50.

414 Salem, P. (2012, June 19). Can Hezbollah Weather the Arab Spring? Retrieved March 5, 2013 from Project Syndicate: http://www.project-syndicate.org/commentary/canhezbollah-weather-the-arab-spring
} 
external powers ${ }^{415}$. For Hizbullah the Syrian uprising is the result of imperialistic influences and it is these that must be resisted.

The civil war in Syria is currently far from decided, and what eventuates afterwards will be a significant determinant in Hizbullah's future. Hizbullah's instrumental approach of identifying itself primarily as a resistance movement may yet eventually backfire. This identity placed Hizbullah along side both Syria and Iran in an "axis of resistance" against Israel ${ }^{416}$. With the dissolution of this axis, the organisation may be perceived as significantly weakened. Subsequently, it could be faced with significant threats politically within Lebanon, and externally from Israel. It may therefore find that it now needs to adopt a more moderate path. Hizbullah has displayed moderation in the past; its downplaying of its initial calls for revolution despite its then Shi'a revolutionary identity, as well as the moderation displayed in its manifesto released in 2009, suggest an astuteness towards the dynamic political and operational arenas it finds itself operating in. The organisation may need to astutely moderate and modify its identity again to navigate the future without its traditional political patrons.

415 Berti, B. (2012). Beyond the "Divine Victory": New Challenges Facing Hizbollah. Strategic Assessment, 14 (4), p. 106.

416 Berti, Israel Journal of Foreign Affairs, p. 27. 


\section{Bibliography}

Abdul-Hussain, H. (2009). Hezbollah: The State within a State. Current Trends in Islamist Ideology , 8.

Abraham, A. J. (2008). Lebanon in Modern Times. Lanham, Maryland:

University Press of America.

Abraham, A. J. (1996). The Lebanon War. Westport: Praegar Publishers.

Abrahamian, E. (2008). A History of Modern Iran. New York: Cambridge University Press.

Ajami, F. (2005). The Autumn of the Autocrats. Foreign Affairs , 84 (3), pp. 20-35.

Ajami, F. (1986). The Vanished Imam. London: Cornell University Press.

Akho-Rashida, A. M., \& Barari, H. A. (2010). The Pragmatic and The Radical. Israel and Hizbollah: An Asymmetric Conflict in Historical and Comparative Perspective (Kindle iPad). (C. Jones, \& S. Catignani, Eds.) New York: Routledge.

Al Jazeera Satellite Channel. (2004). The Accord To End The War. War In Lebanon, Ep. 15 . Doha, Qatar.

Alagha, J. E. (2006). The Shifts in Hizbullah's Ideology: Religious Ideology, Political Ideology, and Political Program. Amsterdam: Amsterdam University Press.

Alagha, J. (2011). Hizbullah's Documents: From the 1985 Open Letter to the 2009 Manifesto. Amsterdam, 2011: Pallas Publications.

Allain, J. (2004). International Law in the Middle East: Closer to Power than Justice. Aldershot, England: Ashgate Publishing Limited.

Amnesty International. (1975). Annual Report 1974-75. Geneva: Amnesty International.

Arjomand, S. A. (1989). The Turban For The Crown: The Islamic Revolution in Iran. New York: Oxford University Press.

Atzili, B. (2010). State Weakness and "Vacuum of Power" in Lebanon. Studies in Conflict \& Terrorism, 33 (8), pp. 757-782.

Avon, D., \& Khatchadourian, A.-T. (2012). Hezbollah: A History of the "Party of God". (J. M. Todd, Trans.) Cambridge, Massachusetts: Harvard University Press. 
Axtmann, R. (2004). The State of the State: The Model of the Modern State and Its Contemporary Transformation. International Political Science Review, 25 (3), pp. 259-279.

Baliani, D. (2008). Lebaon: The Doha Agreement Ends the first Restructuring Phase in the Post-Syrian Lebanon. CeMiss Quarterly, 6 (2), 61.

Berti, B. (2012). Beyond the "Divine Victory": New Challenges Facing Hizbollah. Strategic Assessment, 14 (4), pp. 103-114.

Berti, B. (2012). Hizbullah, Hamas, and the "Arab Spring" - Weathering the Regional Storm? Israel Journal of Foreign Affairs , 6 (3), pp. 21-29.

Berti, B. (2010). The "Rebirth" of Hizbollah: Analyzing the 2009 Manifesto. Strategic Assessment, 12 (4), pp. 91-100.

Binder, L. (1966). Politics in Lebanon. New York: Wiley.

Blanford, N. (2008, May 7). A Cell Phone War in Lebanon. Retrieved February 7, 2013 from Time World: http://www.time.com/time/world/article/0,8599,1738255,00.html

Borghei, M. (1992). Iran's Religious Establishment: The Dialectics of Politicization. In S. K. Farsoun, \& M. Mashayekhi (Eds.), Iran: Political Culture in the Islamic Republic (p. 269). Arbington, Oxon, England: Routledge.

Brynen, R. (1989). PLO Policy in Lebanon: Legacies and Lessons. Journal of Palestinian Studies, 18 (2), pp. 48-70.

Byman, D. (2005). Deadly Connections: States that Sponsor Terrorism. New York: Cambridge University Press.

Cammett, M., \& Issar, S. (2010). Bricks and Mortar Clientelism: Sectarianism and the Logics of Welfare Allocation in Lebanon. World Politics , 62 (3), pp. $381-421$

Carter, J. (1977, December 31). Tehran, Iran: Toasts of the President and the Shah at a State Dinner. Retrieved January 16, 2013 from The American Presidency Project: http://www.presidency.ucsb.edu/ws/?pid=7080

Chamie, J. (1976). The Lebanese Civil War: An Investigation into the Causes. World Affairs , 139 (3), pp. 171-188.

Chandra, K. (2012). Introduction. In C. Kanchan (Ed.), Constructivist Theories of Ethnic Politics (p. 520). New York: Oxford University Press.

Choucair, J. (2006). Lebanon: Finding a Path from Deadlock to Democracy. Carnegie Endowment for International Peace. Washington DC: Carnegie Endowment for International Peace Publications Department. 
Cleveland, W. L. (2004). A History of the Modern Middle East. Boulder, Colorado: Westview Press.

Cobban, H. (1985). The Making of Modern Lebanon. London: Hutchinson Publishing Group.

Cobban, H. (1985). The Palestinian Liberation Organisation: People, Power and Politics. New York: Cambridge University Press.

Dekmejian, R. H. (1978). Consociational Democracy in Crisis: The Case of Lebanon. Comparative Politics , 10 (2).

Diehl, J. (1989, October 20). Israel Seems Ready To Linger in S. Lebanon. The Washington Post, p. A33.

Emadi, H. (1995, January). Exporting Iran's Revolution: The Radicalization of the Shiite Movement in Afghanistan. Middle Eastern Studies , pp. 1-12.

Enayat, H. (2005). Modern Islamic Political Thought. London: I. B. Tauris \& Co Ltd.

Faour, M. A. (2007). Religion, Demography, and Politics in Lebanon. Middle Eastern Studies , 43 (6), pp. 909-921.

Filkins, D. (2013, February 25). After Syria: If the Assad regime falls, can Hezbollah survive? The New Yorker, pp. 48-57.

Firro, K. (2002). Inventing Lebanon: Nationalism and the State Under the Mandate. London: I. B. Tauris \& Co Ltd.

Fisk, R. (2006, December 15). Who's Running Lebanon? Retrieved December 13, 2012 from The Independent:

http://www.independent.co.uk/voices/commentators/fisk/robert-fiskwhos-running-lebanon-428530.html

Flanigan, S. T., \& Abdel-Samad, M. (2009). Hezbollah's Social Jihad: Nonprofits as Resistance Organisations. Middle East Policy , 16 (2), pp. 122137.

Fouad, A. (1981, April 20). Lebanon: Myth and Reality. The New York Times , p. 19.

Fuller, G. E., \& Francke, R. R. (2000, March). Is Shi'ism Radical? Middle East Quarterly, pp. 11-20.

Geertz, C. (1963). The Integrative Revolution: Primordial Sentiments and Civil Politics in the New States. In C. Geertz (Ed.), Old Societies and New States (p. 310). London: Collier-MacMillan Ltd. 
Geertz, C. (1993). The Interpretation of Cultures: Selected Essays. London: Fontana.

Gilley, B. (2004). Against the Concept of Ethnic Conflict. Third World Quarterly, 25 (6), pp. 1155-1166.

Hahn, P. (2006). Securing the Middle East: The Eisenhower Doctrine of 1957. Presidential Studies Quarterly, 36 (1), pp. 38-47.

Hamzeh, A. N. (2004). in The Path Of Hizbullah. Syracuse, New York: Syracuse University Press.

Harb, M., \& Leenders, R. (2005). Know They Enemy: Hizbullah, 'Terrorism' and the Politics of Perception. Third World Quarterly, 26 (1), pp. 173-197.

Harik, J. P. (2004). Hezbollah: The Changing Face of Terrorism. London: I. B. Tauris \& Co Ltd.

Hempel, L. (2004). What's It Worth To You? The Questionable Value of Instrumentalist Approaches to Ethnic Identification. International Journal of Comparative Sociology , 45 (3-4), pp. 253-275.

Hinchcliffe, P., \& Milton-Edwards, B. (2009). Jordan: A Hashemite Legacy. (2nd Edition). New York, Routledge.

Horowitz, D. L. (2000). Ethnic Groups in Conflict. London: University of California Press, Ltd.

Hudson, M. C. (1968). The Precarious Republic: Political Modernization in Lebanon. 1968: Random House.

Hudson, M. C. (1997). Trying Again: Power-Sharing in Post-Civil War Lebanon. International Negotiation , 2, pp. 103-122.

International Foundation for Electoral Systems. (2009, June 9). Lebanon's 7 June Elections: The Results. Retrieved February 15, 2013 from International Foundation for Electoral Systems:

http://www.ifes.org/files/IFES_LebanonReview060709Results.pdf

Isaacs, H. (1975). Idols of the Tribe: Group Identity and Political Change. New York: Harper \& Row Publishers.

Jesse, N. G., \& Williams, K. P. (2010). Ethnic Conflict: A Systematic Approach to Cases of Conflict. Washington: QC Press.

Johnson, M. (1983). Popular Movements and Primordial Loyalties in Beirut. In T. Asad, \& R. Owen (Eds.), Sociology of "Developing Societies": The Middle East (pp. 178-194). New York: Monthy Review Press. 
Kaufman, A. (2004). Understanding The Shebaa Farms Dispute: Roots of the Anomaly and Prospects of Resolution. Palestine-Israel Journal of Politics, Economics, and Culture , 11 (1), pp. 37-43.

Kaufman, A. (2002). Who Owns the Shebaa Farms? Chronicle of a Territorial Dispute. The Middle East Journal , 56 (4), pp. 576-596.

Khadduri, M. (1969). Republican Iraq: A Study in Iraqi Politics since the Revolution in 1958. London: Oxford University Press.

Khalaf, S. (1968). Primordial Ties and Politics in Lebanon. Middle Eastern Studies , 4 (3), pp. 243-269.

Khatib, L. (2011). Hizbullah's Political Strategy. Survival: Global Politics and Strategy , 53 (2), pp. 61-76.

Kliot, N. (1987). The Collapse of the Lebanese State. Middle Eastern Studies, 23 (1), pp. 54-74.

Knio, K. (2005). Lebanon: Cedar Revolution or Neo-Sectarian Partition? Mediterranean Politics , 10 (2), pp. 225-231.

Krayem, H. (1997). The Lebanese Civil War and the Taif Agreement. In P. Salem (Ed.), Conflict Resolution in the Arab World: Selected Essays (p. 482). Beirut: American University of Beirut.

Ladki, N. (2009, November 30). Hezbollah Cuts Islamist rhetoric in new manifesto. Retrieved January 20, 2013 from Reuters:

http://www.reuters.com/article/2009/11/30/us-lebanon-hezbollahidUSTRE5AT3VK20091130

Lijphart, A. (1984). Democracies: Patterns of Majoritarian and Consensus Government in Twenty-One Countries. New Haven: Yale University Press.

Lijphart, A. (1968, April). Typologies of Democratic Systems. Comparative Political Studies , pp. 3-44.

Lipset, S. M., \& Rokkan, S. (Eds.). (1967). Party Systems and Voter Alignments: Cross-National Perspectives. New York: Free Press.

Majed, Z. (2011, September 8). On Consociationalism and Confessionalism in Lebanon. Near East Quarterly, pp. 1-8.

Martin, C. (2012). Consociational Politics: The Influence of Hezbullah on the Stability of Sectarianism in Lebanon. Journal of Political Inquiry at New York University , 5 (5), 27. 
McGarry, J., \& O'Leary, B. (2004). The Northern Ireland Conflict: Consociational Engagements. Oxford: Oxford University Press.

Milani, M. M. (1994). The Making of Iran's Islamic Revolution (2nd Edition). Boulder, Colorado: Westview Press, Inc.

Milani, M. (1992). Shi'ism and the State in the Constitution of The Islamic Republic of Iran. In S. K. Farsoun, \& M. Mashayekhi (Eds.), Iran: Political Culture in the Islamic Republic (p. 269). Arbingdon, Oxon, England: Routledge.

National Broadcasting Network. (2003). Hizbullah 1982 - 2002. The Lebanese Parties , Ep. 7 . (Unknown, Trans.) Beirut, Lebanon.

NBN. (2003). The Hizbollah Organization 1982-1991. The Lebanese Parties, Disc 7(Part 1). Beirut, Lebanon: National Broadcasting Network (NBN).

Noe, N. (Ed.). (2007). Voice of Hezbollah: The Statements of Sayyed Hassan Nasrallah. (E. Khouri, Trans.) New York: Verso.

Norton, A. R. (1987). Amal and the Shi'a. Austin, Texas: University of Texas Press.

Norton, A. R. (2007). Hezbollah. Princeton: Princeton University Press.

Norton, A. R. (2000). Hizballah of Lebanon: Extremist Ideals vs. Mundane Politics. Council on Foreign Relations. New York: Council on Foreign Relations Press.

Norton, A. R. (1998). Hizballah: From Radicalism to Pragmatism? Middle East Policy, 5 (4), pp. 147-158.

Olzak, S. (1983). Contemporary Ethnic Mobilization. Annual Review of Sociology, 9, pp. 355-374.

Owen, R. (1984). The Lebanese Crisis: Fragmentation or Reconciliation? Third World Quarterly , 6 (4), pp. 934-949.

Qassem, N. (2005). Hizbullah: The Story From Within. (D. Khalil, Trans.) London: Saqi.

Rabil, R. G. (2012). Hezbollah, The Islamic Association and Lebanon's Confessional System. The Levantine Review , 1 (1), pp. 49-67.

Rabinovich, I. (1986). The War For Lebanon: 1970-1985. Ithaca, New York: Cornell University Press. 
Salamey, I., \& Copeland, G. (2011). How exceptional are Islamists? Comparing Support for Hezbollah and the Lebanese Forces. Journal of Balkan and Near Eastern Studies , 13 (2), pp. 157-175.

Salamey, I., \& Payne, R. (2008). Parliamentary Consociationalism in Lebanon: Equal Citizenry vs. Quotated Confessionalism. The Journal of Legislative Studies , 14 (4), pp. 451-473.

Salem, P. (2012, June 19). Can Hezbollah Weather the Arab Spring? Retrieved March 5, 2013 from Project Syndicate: http://www.projectsyndicate.org/commentary/can-hezbollah-weather-the-arab-spring

Salibi, K. (1988). A House of Many Mansions: The History of Lebanon Reconsidered. 1988: Univesity of California Press.

Saouli, A. (2006). Stability Under Late State Formation: The Case Of Lebanon. Cambridge Review Of International Affairs , 19 (4), pp. 701-717.

Saseen, S. M. (1990). The Taif Accord and Lebanon's Struggle to Regain its Sovereignty. American University International Law Review , 6 (1), pp. 57-75.

Schwerna, T. (2010). Lebanon: A Model of Consociational Conflict. Frankfurt am Main: Peter Lang.

Shaery-Eisenlohr, R. (2008). Shi'ite Lebanon: Transnational Religion and the Making of National Identities. New York: Columbia University Press.

Shanahan, R. (2003). Radical Islamist Groups in the Modern Age: A Case Study of Hizbullah. Australian National University, Strategic \& Defence Studies Centre. Canberra: Australian National University.

Shanahan, R. (2011). The Shi'a of Lebanon (2nd Edition ed.). London: I. B. Tauris \& Co Ltd.

Shils, E. (1966). Introduction. In L. Binder (Ed.), Politics in Lebanon (p. 345). New York: John Wiley and Sons.

Sirriyeh, H. (2010). The Emergence of Hizbollah and the Beginnings of Resistance, 1982-85. Israel and Hizbollah: An Asymmetric Conflict in Historical and Comparative Perspective (Kindle iPad). (C. Jones, \& S. Catignani, Eds.) New York: Routledge.

Smith, A. D. (1990). The Suppression of Nationalism. International Journal of Contemporary Sociology , 28 (1), pp. 1-31.

Smith, A. (2010). Nationalism: Theory, Ideology, History. Cambridge: Polity. 
Sobelman, D. (2010). Hizbollah - From Terror to Resistance. In C. Jones, \& S. Catignani (Eds.), Israel and Hizbollah: An Assymetric Conflict in Historical and Comparative Perspective. New York: Routledge.

Steinberg, G. M. (2007). Foreign Policy in the 1999 Israeli Elections. Israel Affairs , 7 (2-3), pp. 173-198.

Tabbarah, R. B. (1979). Background to the Lebanese Conflict. International Journal of Comparative Sociology , 20 (1-2), pp. 101-121.

The Arab League. (2009, July 18). The Ta'if Accord. Retrieved January 12, 2013 from Al-Bab: http://www.al-bab.com/arab/docs/lebanon/taif.htm

The United Nations (UN). (1978, March 19). Security Council Resolutions. Retrieved December 5, 2012 from United Nations Security Council: http://www.un.org/ga/search/view_doc.asp?symbol=S/RES/425(1978)

The United Nations (UN). (1982, June 5). Security Council Resolutions. Retrieved December 5, 2012 from The United Nations Security Council: http://www.un.org/ga/search/view_doc.asp?symbol=S/RES/508(1982)

The United Nations Security Council. (2006, August 11). Resolution 1701. Retrieved February 10, 2013 from The United Naitons :

http://www.un.org/News/Press/docs/2006/sc8808.doc.htm

Weber, M. (1968). Ethnic Groups. In M. Weber, G. Roth, \& C. Wittich (Eds.), Economy and Society: An Outline of Interpretive Sociology (E. Fischoff, Trans., Vol. 1, p. 1469). New York: Bedminster Press.

Wege, C. A. (1994). Hizbollah Organisation. Studies in Conflict and Terrorism, 17.

Wheeler, C., \& Gilbert, B. (2008, 5 10). Lebanese Army won't take on Hizbollah. Retrieved 1 10, 2013 from The Telegraph: http://www.telegraph.co.uk/news/worldnews/middleeast/lebanon/19447 37/Lebanese-army-wont-take-on-Hizbollah.html

Yiftachel, 0. (1992). The State, Ethnic Relations and democratic Stability: Lebanon, Cyprus and Israel. GeoJournal , 28 (3), pp. 319-332.

Zisser, E. (2003). Hizballah. In B. Rubin (Ed.), Revolutionaries and Reformers: Contemporary Islamist Movements in the Middle East (pp. 91-103). New York: State University of New York Press.

Zisser, E. (2002). The Return of Hizbullah. Middle East Quarterly, 9 (4), pp. 3-11. 
